Supporting Information

\title{
Copper-Mediated Oxidative Fluorination of Aryl Stannanes with Fluoride
}

\author{
Raymond F. Gamache, ${ }^{\dagger}$ Christopher Waldmann and Jennifer M. Murphy*, \\ †Department of Chemistry and Biochemistry, „Department of Molecular and Medical \\ Pharmacology and Crump Institute for Molecular Imaging, David Geffen School of \\ Medicine \\ University of California Los Angeles \\ Los Angeles, California 90095, United States \\ Email: jmmurphy@mednet.ucla.edu
}




\section{Table of Contents}

I. General Procedures and Materials and Methods S3

II. Experimental Data $\quad$ S4

A. Synthesis of Aryl Stannanes $\quad$ S4

B. Synthesis of aryl fluoride reference compounds S6

$\begin{array}{lr}\text { C. Optimization Data } & \text { S7 }\end{array}$

D. Synthesis and Characterization of the Fluorinated Products $\quad$ S12

$\begin{array}{ll}\text { III. References } & \text { S20 }\end{array}$

IV. ${ }^{1} \mathrm{H},{ }^{13} \mathrm{C}$, and ${ }^{19}$ F NMR Spectra $\quad$ S21 


\section{General Procedures}

NMR spectra were obtained on a Bruker AV300 (300 MHz for ${ }^{1} \mathrm{H} ; 282 \mathrm{MHz}$ for ${ }^{19} \mathrm{~F}$ ), a Bruker AV500 (500 MHz for ${ }^{1} \mathrm{H}$; $125 \mathrm{MHz}$ for ${ }^{13} \mathrm{C}$ ), and a Bruker AV600 (600 MHz for ${ }^{1} \mathrm{H} ; 150 \mathrm{MHz}$ for ${ }^{13} \mathrm{C}$ ). ${ }^{1} \mathrm{H}$ and ${ }^{13} \mathrm{C}$ chemical shifts are reported in parts per million (ppm) using the solvent resonance as an internal reference. ${ }^{19} \mathrm{~F}$ NMR spectra are calibrated to the internal standard 1-fluoro-3-nitrobenzene, which appears at -112.0 ppm. The coupling constants, J, are reported in Hertz $(\mathrm{Hz})$, and the multiplicities are reported as follows: singlet (s), broad single (br s) doublet $(\mathrm{d})$, triplet $(\mathrm{t})$, quartet (q), and multiplet (m). High-resolution electrospray mass spectrometry data was collected with a Waters LCT Premier XE time-of-flight instrument controlled by MassLynx 4.1 software. High-resolution mass spectra were obtained on Thermo Scientific ${ }^{\mathrm{TM}}$ Exactive Mass Spectrometer with DART ID-CUBE. Samples were dissolved in methanol and infused using direct loop injection from a Waters Acquity UPLC into the Multi-Mode Ionization source.

\section{Materials and Methods}

All fluorination reactions were conducted in an inert argon atmosphere glovebox or using standard Schlenk techniques unless otherwise stated. All chemicals and reagents were purchased from commercial sources and used without further purification unless noted otherwise. All deuterated solvents were purchased from Cambridge Isotope Laboratories. (4-chlorophenyl)tributylstannane, [4(benzyloxy)phenyl]tributylstannane, 4-(tributylstannyl)pyridine, tetrabutyl ammonium triphenyldifluorosilicate (TBAT) and 1-fluoro-3-nitrobenzene were purchased from Sigma Aldrich. 4-Pyridyltributylstannane was purchased from Alfa Chemistry. $\mathrm{Cu}(\mathrm{OTf})_{2}$ was purchased from Strem. Anhydrous solvents were obtained by filtration through activated alumina columns unless indicated otherwise. Solvents used for extractions and chromatography were not anhydrous. All other aryl stannanes were synthesized following known literature procedures and characterization data match that which was previously reported. Reactions and 
chromatography fractions were analyzed by thin-layer chromatography (TLC) using Merck precoated silica gel $60 \mathrm{~F}_{254}$ glass plates $(250 \mu \mathrm{m})$ and visualized by ultraviolet irradiation, potassium permanganate stain, and phosphomolybdic acid. Flash column chromatography was performed using E. Merck silica gel 60 (230-400 mesh) with compressed air. Prepatory plate isolation was performed using Merck precoated silica gel $60 \mathrm{~F}_{254}$ glass plates $(1,000 \mu \mathrm{m})$.

\section{Experimental Data}

\section{Synthesis of aryl stannanes}<smiles>CCCCSc1ccc(CNCC)cc1</smiles>

[4-(diethylaminomethyl)phenyl]tributylstannane. To a solution of 4(diethylaminomethyl)-bromobenzene (0.6 g, $2.48 \mathrm{mmol}, 1.0$ equiv) in THF (12 ml) at $-78{ }^{\circ} \mathrm{C}$ was added dropwise $n$-butyl lithium (2.5 M, $1.2 \mathrm{ml}, 2.98 \mathrm{mmol}, 1.2$ equiv). The solution was kept at $-78{ }^{\circ} \mathrm{C}$ and allowed to stir for $10 \mathrm{~min}$. To the reaction mixture was added dropwise a solution of $\mathrm{Bu}_{3} \mathrm{SnCl}(0.843 \mathrm{ml}, 2.98 \mathrm{mmol}, 1.2$ equiv) in THF (3.6 ml) and the reaction was allowed to warm to $23{ }^{\circ} \mathrm{C}$ and stirred for $1 \mathrm{~h}$. The solution was diluted with $48 \mathrm{ml}$ of a 1:1 solution of $\mathrm{Et}_{2} \mathrm{O}$ :hexanes and washed with water $(2 \times 70 \mathrm{ml})$ followed by brine $(40 \mathrm{ml})$. The organic layer was dried over $\mathrm{Na}_{2} \mathrm{SO}_{4}$ and concentrated in vacuo. The desired product was purified by column chromatography $10 \% \quad \mathrm{w} / \mathrm{w} \quad \mathrm{K}_{2} \mathrm{CO}_{3}$ in silica and eluted with 1:9:90 $\mathrm{NEt}_{3}$ :EtOAc:Hexane $(\mathrm{Rf}=0.3)$ to afford $923 \mathrm{mg}$ of the desired compound as a yellow oil (82\% Yield). NMR Spectroscopy: ${ }^{1} \mathrm{H}$ NMR (600 MHz, $\left.\mathrm{CDCl}_{3}\right): \delta 7.39$ (d, J=7.75 Hz, 2H), 7.29 (d, $J=7.26 \mathrm{~Hz}, 2 \mathrm{H}), 3.56$ (s, 2H), 2.54 (br s, 4H), 1.56-1.51 (m, 6H), 1.33 (dd, $J=7.32 \mathrm{~Hz}, 7.32 \mathrm{~Hz}, 3 \mathrm{H}), 1.31$ (dd, $J=7.32 \mathrm{~Hz}, 7.32 \mathrm{~Hz}, 3 \mathrm{H}), 1.06-1.02$ (m, $12 \mathrm{H}), 0.88(\mathrm{t}, J=7.32 \mathrm{~Hz}, 9 \mathrm{H}) .{ }^{13} \mathrm{C} \mathrm{NMR}\left(150 \mathrm{MHz}, \mathrm{CDCl}_{3}\right): \delta 139.66,136.37,136.17$, 128.57, 57.38, 46.60, 29.02, 27.32, 13.61, 11.64, 9.44. HRMS-ESI $(m / z)[M+H]^{+}$calcd for $\mathrm{C}_{23} \mathrm{H}_{44} \mathrm{NSn}$, 454.2495; found 454.2468. 


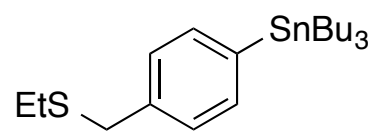

[4-(ethyl-methylenesulfide)phenyl]tributylstannane. To a solution of ethanethiol (0.041 ml, $0.56 \mathrm{mmol}, 1.1$ equiv) in THF (2 ml) at $0{ }^{\circ} \mathrm{C}$ was added $60 \%$ $\mathrm{NaH}\left(0.024 \mathrm{~g}, 0.606 \mathrm{mmol}, 1.15\right.$ equiv). The solution was stirred for $40 \mathrm{~min}$ at $0{ }^{\circ} \mathrm{C}$. To the reaction mixture was added [4-(methylsulfonyl)1methylene]phenyltributylstannane $(0.24 \mathrm{~g}, 1.0$ equiv, $0.51 \mathrm{mmol})$ in THF (1.0 ml) The solution was allowed to stir overnight at $23{ }^{\circ} \mathrm{C}$. The reaction was quenched with water and extracted with ethyl acetate $(2 \times 6 \mathrm{ml})$. The organic layer was washed with $5 \mathrm{ml}$ of $5 \% \mathrm{NaHCO}_{3}$, dried over $\mathrm{Na}_{2} \mathrm{SO}_{4}$ and concentrated in vacuo. The reaction was purified by column chromatography $10 \% \mathrm{w} / \mathrm{w} \mathrm{K}_{2} \mathrm{CO}_{3}$ in silica and eluted with 1:50 EtOAc:Hexane to afford $170.5 \mathrm{mg}$ of the desired compound as a clear oil (69\% Yield) Rf=.3 in hexane. NMR Spectroscopy: ${ }^{1} \mathrm{H}$ NMR (500 MHz, CDCl $)$ : $\delta 7.40(\mathrm{~d}, J=7.85 \mathrm{~Hz}, 2 \mathrm{H}), 7.27(\mathrm{~d}, J=7.30 \mathrm{~Hz}, 2 \mathrm{H}), 3.70(\mathrm{~s}, 2 \mathrm{H}), 2.45(\mathrm{q}, J=7.49 \mathrm{~Hz}$, 2H), 1.58-1.47 (m, 6H), 1.37-1.28 (m, 6H), $1.24(\mathrm{t}, J=7.35 \mathrm{~Hz}, 3 \mathrm{H}), 1.11-0.97(\mathrm{~m}, 6 \mathrm{H})$, $0.88(\mathrm{t}, J=7.30 \mathrm{~Hz}, 9 \mathrm{H}) .{ }^{13} \mathrm{C} \operatorname{NMR}\left(150 \mathrm{MHz} \mathrm{CDCl}_{3}\right): \delta 140.18,138.09,136.46$, $128.24,35.83,28.97,27.25,25.21,14.27,13.54,9.44$. HRMS-ESI $(m / z)[\mathrm{M}+\mathrm{H}]^{+}$calcd for $\mathrm{C}_{21} \mathrm{H}_{39} \mathrm{SSn}, 443.1794$; found 443.1765 .

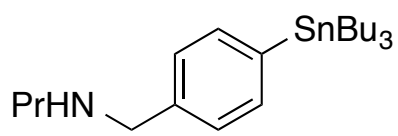

[4-(propylaminomethyl)phenyl]tributylstannane. To a solution of propylamine (0.21 ml, 2.4 mmol, 1.1 equiv), $\mathrm{K}_{2} \mathrm{CO}_{3}$ (0.594 g, $4.3 \mathrm{mmol}, 2.0$ equiv) in DMF (9 ml) was added [4-(chloromethyl)phenyl]tributylstannane (900 mg, $2.18 \mathrm{mmol}, 1$ equiv) after 30 min of stirring. The reaction was monitored by TLC and allowed to stir until complete consumption of starting material. The mixture was diluted with $\mathrm{Et}_{2} \mathrm{O}$ $(10 \mathrm{~mL})$ and water $(10 \mathrm{~mL})$. The organic layer was separated and washed with water $(3 \times 3 \mathrm{~mL})$ followed by brine $(3 \mathrm{~mL})$. The organic layer was dried over $\mathrm{Na}_{2} \mathrm{SO}_{4}$ and concentrated in vacuo. The desired product was purified by column 
chromatography $10 \% \quad \mathrm{w} / \mathrm{w} \quad \mathrm{K}_{2} \mathrm{CO}_{3}$ in silica and eluted with 1:19:80 $\mathrm{NEt}_{3}:$ EtOAc:Hexane $(\mathrm{Rf}=0.25)$ to afford $350 \mathrm{mg}$ of the desired compound as a yellow oil (37\% yield). NMR Spectroscopy: ${ }^{1} \mathrm{H}$ NMR $\left(600 \mathrm{MHz}, \mathrm{CDCl}_{3}\right): \delta 7.45$ (d, $J=$ $7.02 \mathrm{~Hz}, 2 \mathrm{H}$ ), 7.31 (d, $J=8.40 \mathrm{~Hz}, 2 \mathrm{H}), 3.79(\mathrm{~s}, 2 \mathrm{H}), 2.63$ (dd, $J=7.08 \mathrm{~Hz}, 7.10 \mathrm{~Hz}, 2 \mathrm{H}$ ), 2.26 (s 1H), $1.58-1.53$ (m, 8H), 1.36 (dd, $J=7.5 \mathrm{~Hz}, 7.5 \mathrm{~Hz}, 3 \mathrm{H}$ ), 1.34 (dd, $J=7.3,7.3$ $\mathrm{Hz}, 3 \mathrm{H}), 1.10-1.05(\mathrm{~m}, 6 \mathrm{H}), 0.94(\mathrm{t}, J=7.32 \mathrm{~Hz}, 3 \mathrm{H}), 0.90(\mathrm{t}, J=7.32 \mathrm{~Hz}, 9 \mathrm{H}) .{ }^{13} \mathrm{C}$ NMR (150 MHz, $\left.\mathrm{CDCl}_{3}\right): \delta 140.23,139.86,136.57,127.84,53.97,51.35,29.10,27.39$, 23.08, 13.69, 11.79, 9.55. HRMS-ESI $(\mathrm{m} / \mathrm{z})[\mathrm{M}+\mathrm{H}]^{+}$calcd for $\mathrm{C}_{22} \mathrm{H}_{42} \mathrm{NSn}, 440.2339$; found 440.2305 .

\section{Synthesis of aryl fluoride reference compounds}

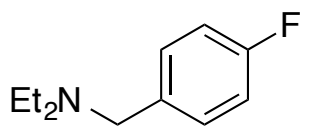

reference standard

$\boldsymbol{N}, \boldsymbol{N}$-diethyl-(4-fluorobenzyl)amine. Diethylamine ( $3.5 \mathrm{mmol}, 0.36 \mathrm{ml}, 2.2$ equiv) was added to a solution containing DCM $(2 \mathrm{ml})$ and 4-fluorobenzylbromide (1.6 mmol, $0.2 \mathrm{ml}, 1$ equiv) at $0{ }^{\circ} \mathrm{C}$. The solution was allowed to warm to $23{ }^{\circ} \mathrm{C}$ and stirred overnight. The organic layer was diluted with ethyl acetate and washed with $\mathrm{KOH}(2 \times 10 \mathrm{ml})$ and brine $(10 \mathrm{ml})$. The organic layer was dried over $\mathrm{Na}_{2} \mathrm{SO}_{4}$ and concentrated in vacuo resulting in $203 \mathrm{mg}$ of the desired product as a red-orange oil (70\% yield). ${ }^{1} \mathrm{H}$ NMR (500 MHz, $\left.\mathrm{CDCl}_{3}\right): \delta 7.29$ (dd, $\left.J=8.29,5.62 \mathrm{~Hz}, 2 \mathrm{H}\right), 6.98(\mathrm{t}, J=$ $8.73 \mathrm{~Hz}, 2 \mathrm{H}), 3.53(\mathrm{~s}, 2 \mathrm{H}), 2.51(\mathrm{q}, J=7.14 \mathrm{~Hz}, 4 \mathrm{H}), 1.03(\mathrm{t}, J=7.12 \mathrm{~Hz}, 6 \mathrm{H}) .{ }^{13} \mathrm{C}$ NMR (125 MHz, $\mathrm{CDCl}_{3}$ ): $\delta 161.83$ (d, $\left.J=242.78 \mathrm{~Hz}\right), 135.38,130.33$ (d, $\left.J=7.80 \mathrm{~Hz}\right), 114.90$ $(\mathrm{d}, J=21.0 \mathrm{~Hz}), 56.69,46.57,11.63 .{ }^{19} \mathrm{~F} \mathrm{NMR}\left(282 \mathrm{MHz}, \mathrm{CDCl}_{3}\right): \delta-116.47$. 


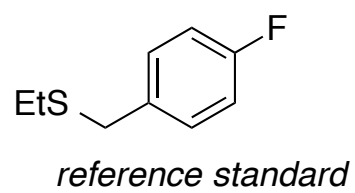

Ethyl 4-fluorobenzyl sulfide. Under argon, THF ( $6 \mathrm{~mL}$ ) was added to ethanethiol (1.32 mmol, $0.095 \mathrm{ml}, 1.1$ equiv) and the mixture was cooled to $0{ }^{\circ} \mathrm{C}$. $\mathrm{NaH}(1.44$ mmol, $58 \mathrm{mg}, 1.2$ equiv) was added, slowly, at $0{ }^{\circ} \mathrm{C}$. The solution was stirred for an additional $20 \mathrm{~min}$ at $0{ }^{\circ} \mathrm{C}$ before 4 -fluorobenzylbromide $(1.2 \mathrm{mmol}, 227 \mathrm{mg}, 1$ equiv) was added. The mixture was allowed to warm to $23^{\circ} \mathrm{C}$ and stirred overnight. The reaction was quenched with water and extracted with ethyl acetate $(2 \times 10 \mathrm{ml})$. The organic layer was washed with $10 \mathrm{ml}$ of $5 \% \mathrm{NaHCO}_{3}$, dried over $\mathrm{Na}_{2} \mathrm{SO}_{4}$ and concentrated in vacuo. The crude oil was purified by silica column chromatography and eluted with hexane to afford $166 \mathrm{mg}$ of the desired compound as a colorless oil (81\% Yield) ${ }^{1} \mathrm{H}$ NMR (500 MHz, $\mathrm{CDCl}_{3}$ ): $\delta 7.31-7.24(\mathrm{~m}, 2 \mathrm{H}), 6.99(\mathrm{dd}, J=8.65 \mathrm{~Hz}$, $8.67 \mathrm{~Hz}, 2 \mathrm{H}), 3.69(\mathrm{~s}, 2 \mathrm{H}), 2.43(\mathrm{q}, J=7.38 \mathrm{~Hz}, 2 \mathrm{H}), 1.23(\mathrm{t}, J=7.40 \mathrm{~Hz}, 3 \mathrm{H}) .{ }^{13} \mathrm{C} \mathrm{NMR}$ $\left(125 \mathrm{MHz}, \mathrm{CDCl}_{3}\right): \delta 161.84(\mathrm{~d}, J=243.63 \mathrm{~Hz}), 134.31(\mathrm{~d}, J=3.16 \mathrm{~Hz}), 130.29(\mathrm{~d}, J=$ $7.98 \mathrm{~Hz}$ ), 115.29 (d, $J=21.28 \mathrm{~Hz}), 35.14,25.22,14.35 .{ }^{19} \mathrm{~F} \mathrm{NMR}\left(282 \mathrm{MHz}, \mathrm{CDCl}_{3}\right): \delta$ 115.91.

\section{Optimization Data:}

\section{Copper Source Screen}

To a vial containing KF (0.05mmol, $2.8 \mathrm{mg}$, 2.0 equiv) and MeCN (300 $\mu \mathrm{l})$ was added a copper salt $(0.05 \mathrm{mmol}, 18.1 \mathrm{mg}, 2.0$ equiv). The vial was sealed with a Teflon cap and removed from the glovebox and stirred for $10 \mathrm{~min}$ at $60{ }^{\circ} \mathrm{C}$. After $10 \mathrm{~min}$, 4(biphenyl)tributylstannane $(0.025 \mathrm{mmol}, 1.0$ equiv) was added and the reaction was stirred at $60{ }^{\circ} \mathrm{C}$ for $3 \mathrm{~h}$ in a sealed vial and subsequently cooled to $23{ }^{\circ} \mathrm{C}$. To the reaction mixture was added 1-fluoro-3-nitrobenzene (3.0 $\mu \mathrm{l}, 0.0282 \mathrm{mmol})$ and MeCN or DCM. The resulting solution was analyzed by ${ }^{19} \mathrm{~F}$ NMR spectroscopy. Yields were determined by comparing the integration of the ${ }^{19} \mathrm{~F}$ NMR resonance of 4-fluorobiphenyl (-118.1 ppm) with that of 1-fluoro-3-nitrobenzene (-112.0 ppm). 
$[\mathrm{Cu}]$ (2 equiv)

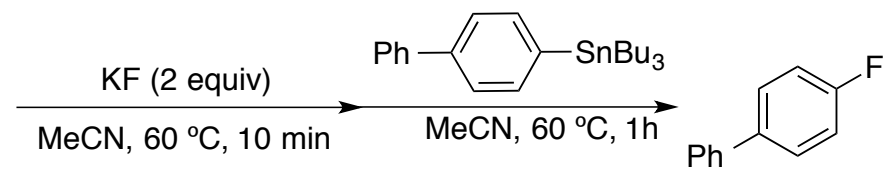

$\begin{array}{ccc}\text { Entry } & {[\mathrm{Cu}]} & \text { Yield } \\ 1 & \mathrm{Cu}(\mathrm{OTf})_{2} & 58 \\ 2 & (\mathrm{MeCN})_{4} \mathrm{CuOTf} & 0 \\ 3 & (\mathrm{py})_{4} \mathrm{Cu}(\mathrm{OTf})_{2} & 0 \\ 4 & \mathrm{CuF}_{2} & 0\end{array}$

\section{Fluoride Source Screen}

To a vial containing the fluoride source $(0.05 \mathrm{mmol}, 2.0$ equiv $)$ and additive in MeCN $(300 \mu \mathrm{l})$ was added $\mathrm{Cu}(\mathrm{OTf})_{2}(0.05 \mathrm{mmol}, 18.1 \mathrm{mg}, 2.0$ equiv). The vial was sealed with a Teflon cap, removed from the glovebox and stirred for $10 \mathrm{~min}$ at $60^{\circ} \mathrm{C}$. After 10 min, 4-(biphenyl)tributylstannane $(0.025 \mathrm{mmol}, 1$ equiv) was added and the reaction was stirred at $60{ }^{\circ} \mathrm{C}$ for $3 \mathrm{~h}$ in a sealed vial and subsequently cooled to 23 ${ }^{\circ} \mathrm{C}$. To the reaction mixture was added 1-fluoro-3-nitrobenzene $(3.0 \mu \mathrm{l}, 0.0282$ mmol) and MeCN or DCM (0.5 ml). The resulting solution was analyzed by ${ }^{19} \mathrm{~F}$ NMR spectroscopy. Yields were determined by comparing the integration of the ${ }^{19} \mathrm{~F}$ NMR resonance of 4-fluorobiphenyl (-118.1 ppm) with that of 1-fluoro-3-nitrobenzene ($112.0 \mathrm{ppm}$ ).

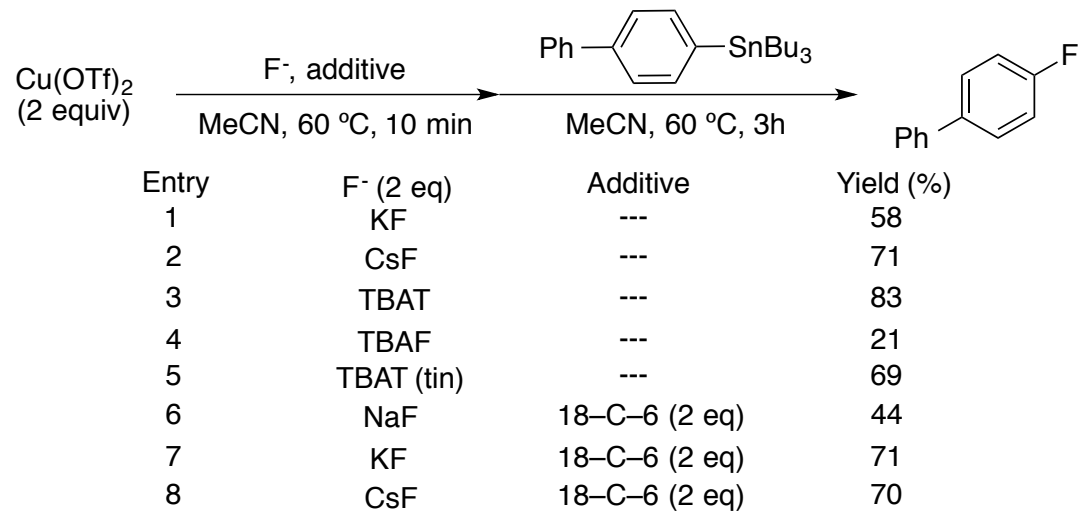




\section{Effect of pre-stirring}

To a vial containing a fluoride source $(0.05 \mathrm{mmol}, 2.0$ equiv) in $\mathrm{MeCN}(300 \mu \mathrm{l})$ was added $\mathrm{Cu}(\mathrm{OTf})_{2}(0.05 \mathrm{mmol}, 18.1 \mathrm{mg}, 2.0$ equiv). The vial was sealed with a Teflon cap, removed from the glovebox and stirred at $60{ }^{\circ} \mathrm{C}$ for the indicated time. 4(biphenyl)tributylstannane $(0.025 \mathrm{mmol}, 1.0$ equiv) was added and the reaction was stirred at $60{ }^{\circ} \mathrm{C}$ for $3 \mathrm{~h}$ in a sealed vial and subsequently cooled to $23{ }^{\circ} \mathrm{C}$. To the reaction mixture was added 1-fluoro-3-nitrobenzene $(3.0 \mu \mathrm{l}, 0.0282 \mathrm{mmol})$ and $\mathrm{MeCN}$ or DCM. The resulting solution was analyzed by ${ }^{19} \mathrm{~F}$ NMR spectroscopy. Yields were determined by comparing the integration of the ${ }^{19} \mathrm{~F}$ NMR resonance of 4-fluorobiphenyl (-118.1 ppm) with that of 1-fluoro-3-nitrobenzene (-112.0 ppm).

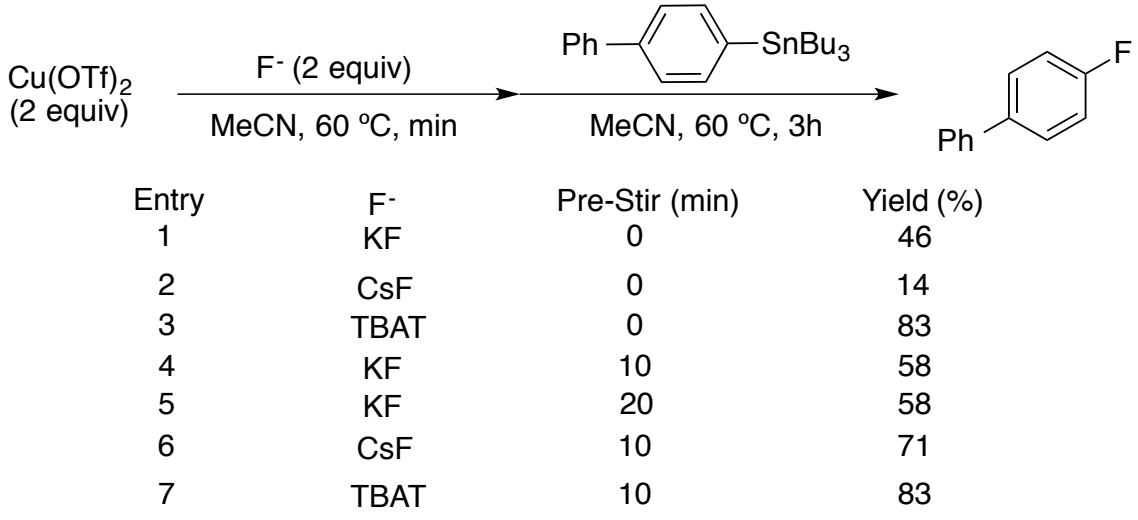

\section{Nitrile Solvent Screen}

To a vial containing CsF ( $0.05 \mathrm{mmol}, 27 \mathrm{mg}, 2.0$ equiv) in $300 \mu \mathrm{l}$ of various nitrile solvents was added $\mathrm{Cu}(\mathrm{OTf})_{2}(0.05 \mathrm{mmol}, 18.1 \mathrm{mg}, 2.0$ equiv). The reaction mixture was stirred in a sealed vial at $60{ }^{\circ} \mathrm{C}$ for $10 \mathrm{~min}$. After $10 \mathrm{~min}$ 4(biphenyl)tributylstannane $(0.025 \mathrm{mmol}, 1.0$ equiv) was added and the reaction was stirred at $60{ }^{\circ} \mathrm{C}$ for $3 \mathrm{~h}$ and subsequently cooled to $23{ }^{\circ} \mathrm{C}$. To the reaction mixture was added 1-fluoro-3-nitrobenzene ( $3.0 \mu \mathrm{l}, 0.0282 \mathrm{mmol})$ and $\mathrm{MeCN}$. The resulting solution was analyzed by ${ }^{19} \mathrm{~F}$ NMR spectroscopy. Yields were determined by comparing the integration of the ${ }^{19} \mathrm{~F}$ NMR resonance of 4-fluorobiphenyl (-118.1 $\mathrm{ppm})$ with that of 1-fluoro-3-nitrobenzene (-112.0 ppm). 


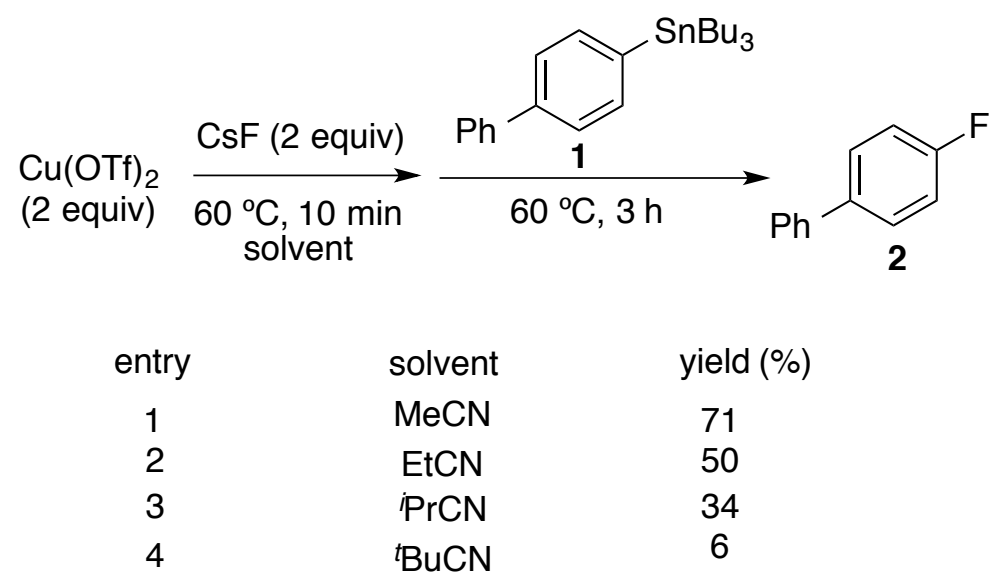

\section{Additives Screen}

To a vial containing CsF $(0.05 \mathrm{mmol}, 27 \mathrm{mg}, 2.0$ equiv) in MeCN (300 $\mu \mathrm{l})$ was added $\mathrm{Cu}(\mathrm{OTf})_{2}(0.05 \mathrm{mmol}, 18.1 \mathrm{mg}, 2.0$ equiv) and an additive. The reaction mixture was stirred in a sealed vial at $60{ }^{\circ} \mathrm{C}$ for $10 \mathrm{~min}$. After 10 min 4(biphenyl)tributylstannane $(0.025 \mathrm{mmol}, 1.0$ equiv) was added and the reaction was stirred at $60{ }^{\circ} \mathrm{C}$ for $3 \mathrm{~h}$ and subsequently cooled to $23{ }^{\circ} \mathrm{C}$. To the reaction mixture was added 1-fluoro-3-nitrobenzene (3.0 $\mu \mathrm{l}, 0.0282 \mathrm{mmol})$ and MeCN or DCM. The resulting solution was analyzed by ${ }^{19} \mathrm{~F}$ NMR spectroscopy. Yields were determined by comparing the integration of the ${ }^{19} \mathrm{~F}$ NMR resonance of 4-fluorobiphenyl (-118.1 $\mathrm{ppm})$ with that of 1-fluoro-3-nitrobenzene (-112.0 ppm).

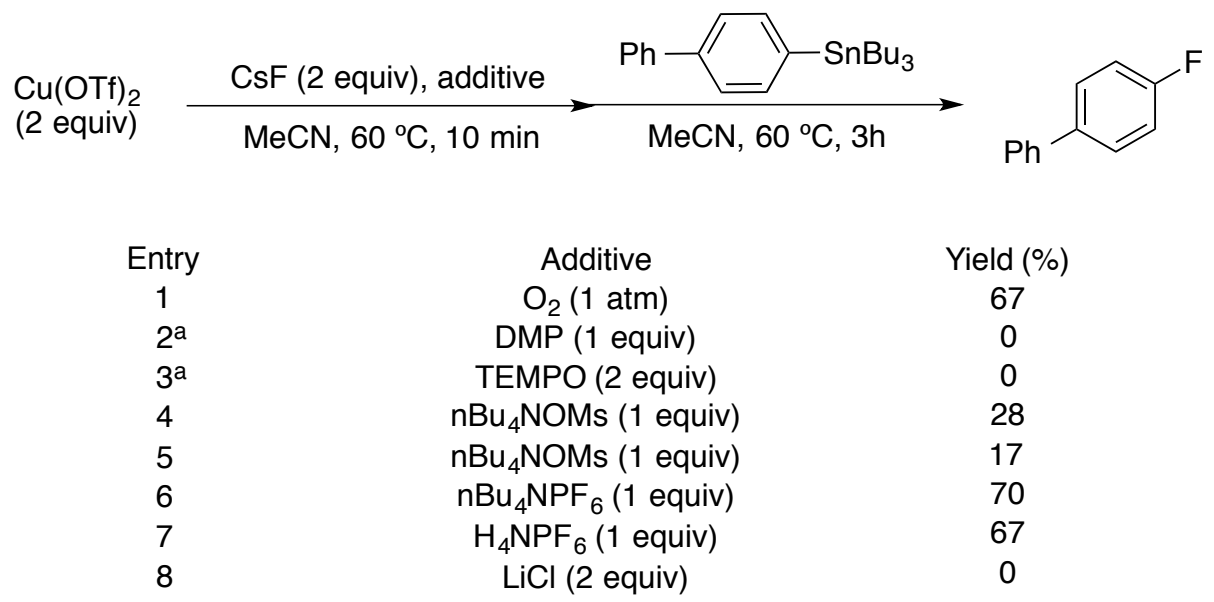

a) TBAT (2 equiv) was used instead of CsF 


\section{Concentration Screen}

To a vial containing CsF $(0.05 \mathrm{mmol}, 7.6 \mathrm{mg}, 2.0$ equiv $)$ in the indicated volume of $\mathrm{MeCN}$ was added $\mathrm{Cu}(\mathrm{OTf})_{2}(0.05 \mathrm{mmol}, 18.1 \mathrm{mg}, 2.0$ equiiv $)$. The vial was then sealed with a Teflon cap, removed from the glovebox and stirred for $10 \mathrm{~min}$ at $60^{\circ} \mathrm{C}$. After $10 \mathrm{~min}$, 4-(biphenyl)tributylstannane ( $0.025 \mathrm{mmol}, 1.0$ equiv) was added and the reaction was stirred at $60{ }^{\circ} \mathrm{C}$ for $3 \mathrm{~h}$ in a sealed vial and subsequently cooled to $23{ }^{\circ} \mathrm{C}$. To the reaction mixture was added 1-fluoro-3-nitrobenzene $(3.0 \mu \mathrm{l}, 0.0282$ mmol) and MeCN or DCM. The resulting solution was analyzed by ${ }^{19} \mathrm{~F}$ NMR spectroscopy. Yields were determined by comparing the integration of the ${ }^{19} \mathrm{~F}$ NMR resonance of 4-fluorobiphenyl (-118.1 ppm) with that of 1-fluoro-3-nitrobenzene ($112.0 \mathrm{ppm})$.

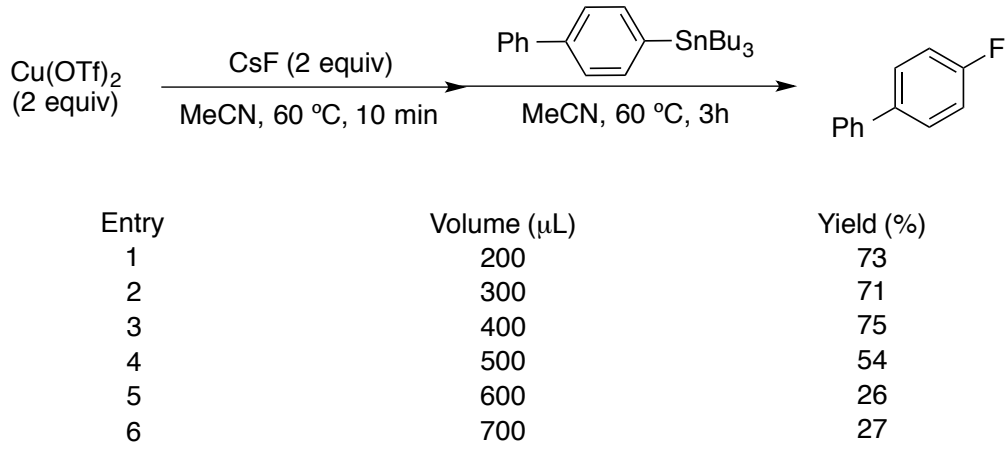

\section{Temperature Screen}

To a vial containing CsF $(0.05 \mathrm{mmol}, 7.6 \mathrm{mg}, 2.0$ equiv) in MeCN $(300 \mu \mathrm{l})$ was added $\mathrm{Cu}(\mathrm{OTf})_{2}(0.05 \mathrm{mmol}, 18.1 \mathrm{mg}, 2.0$ equiv). The vial was then sealed with a Teflon cap, removed from the glovebox and stirred at room temp. After $10 \mathrm{~min}$, 4(biphenyl)tributylstannane $(0.025 \mathrm{mmol}, 1.0$ equiv) was added and the reaction was stirred at the indicated temperature for $2 \mathrm{~h}$ in a sealed vial and subsequently cooled to $23^{\circ} \mathrm{C}$. To the reaction mixture was added 1-fluoro-3-nitrobenzene $(3.0 \mu \mathrm{l}, 0.0282$ mmol) and MeCN or DCM. The resulting solution was analyzed by ${ }^{19} \mathrm{~F}$ NMR spectroscopy. Yields were determined by comparing the integration of the ${ }^{19} \mathrm{~F}$ NMR 
resonance of 4-fluorobiphenyl (-118.1 ppm) with that of 1-fluoro-3-nitrobenzene ($112.0 \mathrm{ppm})$.

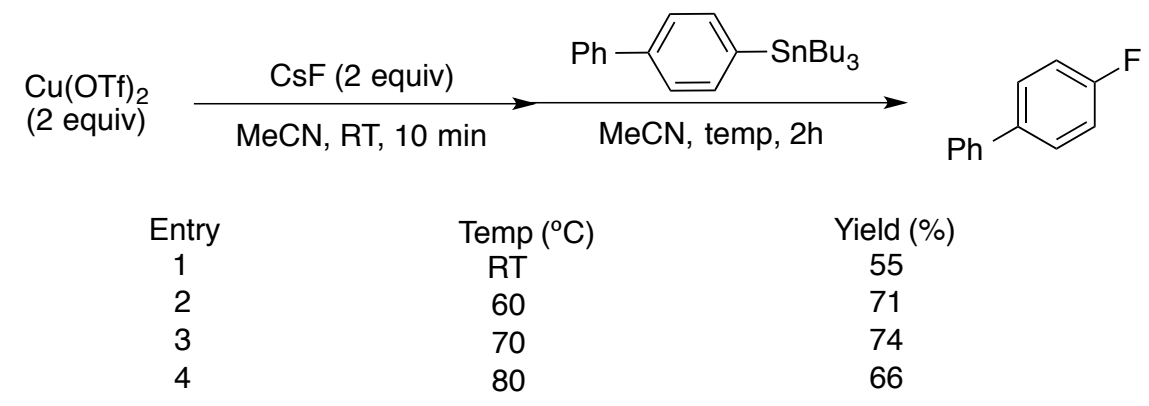

\section{(General Procedure A): Optimized Reaction Condition}

In a glovebox, to a vial containing tetrabutylammonium triphenyldifluorosilicate (TBAT) $\left(0.05 \mathrm{mmol}, 27 \mathrm{mg}, 2.0\right.$ equiv) in $\mathrm{MeCN}(300 \mu \mathrm{l})$ was added $\mathrm{Cu}(\mathrm{OTf})_{2}$ (0.05mmol, $18.1 \mathrm{mg}, 2.0$ equiv). The vial was sealed with a Teflon cap, removed from the glovebox and stirred for $10 \mathrm{~min}$ at $60^{\circ} \mathrm{C}$. After $10 \mathrm{~min}$ the stannane $(0.025$ mmol, 1.0 equiv) was added and the reaction was stirred at $60^{\circ} \mathrm{C}$ for $3 \mathrm{~h}$ in a sealed vial and subsequently cooled to $23^{\circ} \mathrm{C}$. To the reaction mixture was added 1-fluoro3-nitrobenzene ( $3.0 \mu \mathrm{l}, 0.0282 \mathrm{mmol})$ as the internal standard and DCM $(0.5 \mathrm{ml})$. The resulting solution was analyzed by ${ }^{19} \mathrm{~F}$ NMR spectroscopy. Yields were determined by comparing the integration of the ${ }^{19} \mathrm{~F}$ NMR resonance of the product peak with that of 1-fluoro-3-nitrobenzene (-112.0 ppm).

\section{(General Procedure B): Optimized conditions isolation}

In a glovebox, to an $8 \mathrm{ml}$ vial containing tetrabutylammonium triphenyldifluorosilicate (TBAT) (2 equiv) in MeCN was added $\mathrm{Cu}(\mathrm{OTf})_{2}$ (2 equiv) to form a $0.083 \mathrm{M}$ solution. The solution was stirred for $10 \mathrm{~min}$ at $23{ }^{\circ} \mathrm{C}$ and the stannane was added. The vial was sealed with a Teflon cap, removed from the glovebox and stirred for $3 \mathrm{~h}$ at $60{ }^{\circ} \mathrm{C}$. The resulting solution was diluted with $8 \mathrm{ml}$ of $\mathrm{Et}_{2} \mathrm{O}$ and washed with $2 \times 8 \mathrm{ml}$ of water. The organic layer was washed with $2 \times 10 \mathrm{ml}$ of a $0.22 \mathrm{M}$ solution of lithium sulfide. The organic layer was dried over $\mathrm{Na}_{2} \mathrm{SO}_{4}$ and 
concentrated in vacuo at $30^{\circ} \mathrm{C}$. The residue was purified by preparative TLC to afford the desired product.

\section{Substrates}

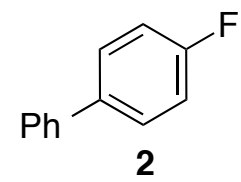

Following general procedure B, 4-fluorobiphenyl was synthesized from (4biphenyl)tributylstannane ${ }^{1}$ in $79 \%$ yield, $31 \mathrm{mg}$ was isolated as a white solid using preparative TLC with $1 \%$ triethylamine in pentane as the eluent. The ${ }^{1} \mathrm{H},{ }^{13} \mathrm{C}$ and ${ }^{19} \mathrm{~F}$ NMR spectroscopic data of the purified material correctly match data previously reported. ${ }^{1}$

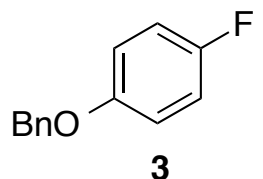

Following general procedure B, 1-(benzyloxy)-4-fluorobenzene was synthesized from [4-(benzyloxy)phenyl]tributylstannane in $66 \%$ yield, $28 \mathrm{mg}$ was isolated as a white solid using preparative TLC with $3 \%$ EtOAc/Hexanes as the eluent. The ${ }^{1} \mathrm{H}$, ${ }^{13} \mathrm{C}$ and ${ }^{19} \mathrm{~F}$ NMR spectroscopic data of the purified material correctly match data previously reported. ${ }^{2}$

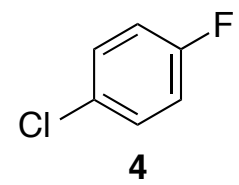

Following general procedure A, 1-chloro-4-fluorobenzene was synthesized from (4chlorophenyl)tributylstannane in $74 \%$ yield as determined by ${ }^{19} \mathrm{~F}$ NMR spectroscopic analysis. ${ }^{19} \mathrm{~F}$ NMR $\left(282 \mathrm{MHz}, \mathrm{CH}_{3} \mathrm{CN}\right): \delta$-117.85. The ${ }^{19} \mathrm{~F}$ NMR spectroscopic data match NMR data for 1-chloro-4-fluorobenzene previously reported in the literature. ${ }^{3}$ 


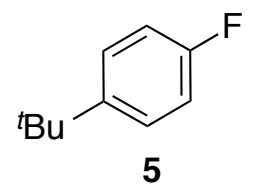

Following general procedure A, fluoro-4-tert-butylbenzene was synthesized from (4-tert-butylphenyl)tributylstannane in $68 \%$ yield as determined by ${ }^{19} \mathrm{~F}$ NMR spectroscopic analysis. ${ }^{19} \mathrm{~F}$ NMR $\left(282 \mathrm{MHz}, \mathrm{CH}_{3} \mathrm{CN}\right): \delta-120.64$. The ${ }^{19} \mathrm{~F}$ NMR spectroscopic data match NMR data for fluoro-4-tert-butylbenzene previously reported in the literature. ${ }^{4}$

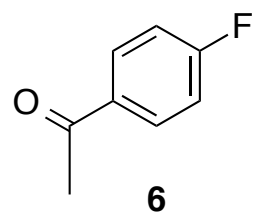

Following general procedure B, 1-acetyl-4-fluorobenzene was synthesized from (4acetylphenyl)tributylstannane ${ }^{5}$ in $59 \%$ yield $(70 \%$ brsm), 20 mg was isolated as a colorless oil using preparative TLC with $3 \% \mathrm{EtOAc} / \mathrm{Hexanes}$ as the eluent. The ${ }^{1} \mathrm{H}$, ${ }^{13} \mathrm{C}$ and ${ }^{19} \mathrm{~F}$ NMR spectroscopic data of the purified material correctly match data previously reported. ${ }^{4}$

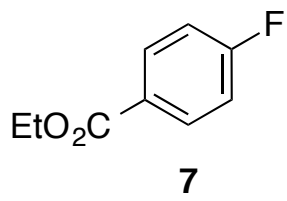

Following general procedure B, ethyl 4-fluorobenzoate was synthesized from ethyl 4-(tributylstannyl)benzoate ${ }^{1}$ in $64 \%$ yield, $25 \mathrm{mg}$ was isolated as a colorless oil using preparative TLC with $3 \%$ EtOAc/Hexane as the eluent. The ${ }^{1} \mathrm{H},{ }^{13} \mathrm{C}$ and ${ }^{19} \mathrm{~F}$ NMR spectroscopic data of the purified material correctly match data previously reported. ${ }^{1}$ 
<smiles>OCc1ccc(F)cc1</smiles>

8

Following general procedure B, 4-fluorobenzyl-alcohol was synthesized from 4(tributylstannyl)benzyl alcohol ${ }^{1}$ in $60 \%$ yield, 19 mg was isolated as a colorless oil using silica gel column chromatography with 10:1 Hexane:EtOAc as the eluent. The ${ }^{1} \mathrm{H},{ }^{13} \mathrm{C}$ and ${ }^{19} \mathrm{~F}$ NMR spectroscopic data of the purified material correctly match data previously reported. ${ }^{1}$

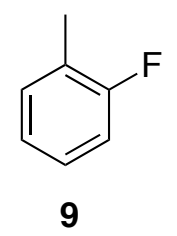

Following general procedure A, 1-fluoro-2-methylbenzene was synthesized from (2methylphenyl)tributylstannane in $50 \%$ yield as determined by ${ }^{19} \mathrm{~F}$ NMR spectroscopic analysis. ${ }^{19} \mathrm{~F}$ NMR $\left(282 \mathrm{MHz}, \mathrm{CH}_{3} \mathrm{CN}\right): \delta-120.07$. The ${ }^{19} \mathrm{~F}$ NMR spectroscopic data match NMR data for 1-fluoro-2-methylbenzene previously reported in the literature. ${ }^{3}$<smiles>O=[N+]([O-])c1ccc(F)cc1</smiles>

10

Following general procedure A, 1-nitro-4-fluorobenzene was synthesized from (4nitrophenyl)tributylstannane ${ }^{5}$ in $58 \%$ yield as determined by ${ }^{19} \mathrm{~F}$ NMR spectroscopic analysis. ${ }^{19} \mathrm{~F}$ NMR $\left(282 \mathrm{MHz}, \mathrm{CH}_{3} \mathrm{CN}\right): \delta-104.87$. The ${ }^{19} \mathrm{~F}$ NMR spectroscopic data match NMR data for 1-nitro-4-fluorobenzene previously reported in the literature. ${ }^{4}$ 


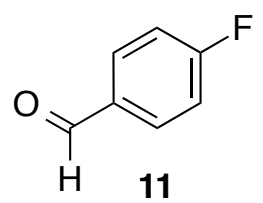

Following general procedure A, 4-fluorobenzaldehyde was synthesized from (4formylphenyl)tributylstannane ${ }^{6}$ in $55 \%$ yield as determined by ${ }^{19} \mathrm{~F}$ NMR spectroscopic analysis. ${ }^{19} \mathrm{~F}$ NMR $\left(282 \mathrm{MHz}, \mathrm{CH}_{3} \mathrm{CN}\right): \delta-105.59$. The ${ }^{19} \mathrm{~F}$ NMR spectroscopic data match NMR data for 4-fluorobenzaldehyde previously reported in the literature. ${ }^{6}$

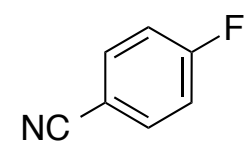

12

Following general procedure A, 1-cyano-4-fluorobenzene was synthesized from (4cyanophenyl)tributylstannane ${ }^{1}$ in $55 \%$ yield as determined by ${ }^{19} \mathrm{~F}$ NMR spectroscopic analysis. ${ }^{19} \mathrm{~F}$ NMR $\left(282 \mathrm{MHz}, \mathrm{CH}_{3} \mathrm{CN}\right): \delta-104.87$. The ${ }^{19} \mathrm{~F}$ NMR spectroscopic data match NMR data for 1-cyano-4-fluorobenzene previously reported in the literature. ${ }^{1}$

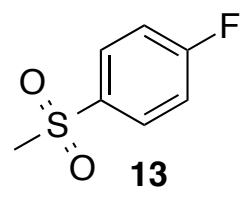

Following general procedure B, 1-fluoro-4-methylsulfonylbenzene was synthesized from [4-(methylsulfonyl)phenyl] tributylstannane, ${ }^{1}$ except stirring was increased to $5 \mathrm{~h} .27 \mathrm{mg}$ of the desired product was isolated as a light yellow solid in $63 \%$ yield using preparative TLC with $50 \%$ EtOAc/Hexane as the eluent. The ${ }^{1} \mathrm{H},{ }^{13} \mathrm{C}$ and ${ }^{19} \mathrm{~F}$ NMR spectroscopic data of the purified material correctly match data previously reported. ${ }^{1}$ 


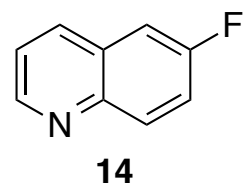

In a glovebox, $\mathrm{Cu}(\mathrm{OTf})_{2}$ ( 4 equiv) was added to a $8 \mathrm{ml}$ vial containing TBAT (2 equiv) and dissolved in $\mathrm{MeCN}$ to form a $0.083 \mathrm{M}$ solution. The solution was stirred for 10 min at $23{ }^{\circ} \mathrm{C}$ after which the 6-(quinolinyl)tributylstannane ${ }^{6}(0.10 \mathrm{~g}, 1$ equiv) was added. The vial was sealed with a teflon cap, removed from the glovebox and stirred for an additional $3 \mathrm{~h}$ at $60{ }^{\circ} \mathrm{C}$. The resulting solution was diluted with $2 \mathrm{ml}$ of $\mathrm{MeCN}$, after which $1 \mathrm{~g}$ of poly-4-vinyl pyridine was added and the mixture was stirred overnight. The solution was diluted with $10 \mathrm{ml}$ of $\mathrm{Et}_{2} \mathrm{O}$, washed with $2 \times 10$ $\mathrm{ml}$ of water and extracted. The organic layer was washed aggressively with $2 \times 10 \mathrm{ml}$ of a $0.22 \mathrm{M}$ solution of lithium sulfide. The organic layer was dried over $\mathrm{Na}_{2} \mathrm{SO}_{4}$, concentrated in vacuo and purified by preparative TLC to give $17 \mathrm{mg}$ of 6fluoroquinoline as a colorless oil in $50 \%$ yield. The ${ }^{1} \mathrm{H},{ }^{13} \mathrm{C}$ and ${ }^{19} \mathrm{~F}$ NMR spectroscopic data of the purified material correctly match data previously reported. ${ }^{6}$

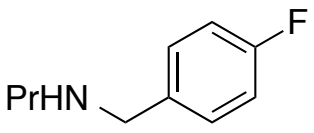

15

In a glovebox, $\mathrm{Cu}(\mathrm{OTf})_{2}(247 \mathrm{mg}, 0.684 \mathrm{mmol}, 4$ equiv) was added to a $8 \mathrm{ml}$ vial containing TBAT (184 mg, $0.342 \mathrm{mmol}, 2$ equiv) and dissolved in MeCN to form a $0.083 \mathrm{M}$ solution. The solution was stirred for $10 \mathrm{~min}$ at $23{ }^{\circ} \mathrm{C}$ after which [4(propylaminomethyl)phenyl]tributylstannane $(75 \mathrm{mg}, 0.171 \mathrm{mmol}, 1$ equiv) was added. The vial was sealed with a teflon cap, removed from the glovebox and stirred for an additional $3 \mathrm{~h}$ at $60{ }^{\circ} \mathrm{C}$. The mixture was diluted with $8 \mathrm{ml}$ of $\mathrm{Et}_{2} \mathrm{O}$ and washed with $3 \times 5 \mathrm{ml}$ of $1.0 \mathrm{~N} \mathrm{HCl}$. The aqueous phase was brought to a $\mathrm{pH}$ of 10 and extracted with $3 \times 10 \mathrm{ml}$ of DCM. The organic layer was dried over $\mathrm{Na}_{2} \mathrm{SO}_{4}$, concentrated in vacuo and purified by preparative TLC using 1:19:80 $\mathrm{NEt}_{3}:$ EtOAc:Hexane to give $14 \mathrm{mg}$ of the desired product as a colorless oil in $49 \%$ 
yield. NMR Spectroscopy: ${ }^{1} \mathrm{H}$ NMR (600 MHz, $\left.\mathrm{CDCl}_{3}\right): \delta 7.28(\mathrm{dd}, J=8.70 \mathrm{~Hz}, 5.52 \mathrm{~Hz}$, 2H), 7.00 (dd, $J=8.76 \mathrm{~Hz}, 8.77 \mathrm{~Hz}, 2 \mathrm{H}$ ), $3.75(\mathrm{~s}, 2 \mathrm{H}), 2.58$ (dd, $J=7.20 \mathrm{~Hz}, 6.10 \mathrm{~Hz}$, 2H), $1.56-1.49(\mathrm{~m}, 3 \mathrm{H}), 0.92(\mathrm{dd}, J=7.44 \mathrm{~Hz}, 7.38 \mathrm{~Hz}, 3 \mathrm{H}) .{ }^{13} \mathrm{C}$ NMR $(125 \mathrm{MHz}$, $\left.\mathrm{CDCl}_{3}\right): \delta 161.9(\mathrm{~d}, J=242.99 \mathrm{~Hz}), 136.19,129.64(\mathrm{~d}, J=7.87 \mathrm{~Hz}), 115.12(\mathrm{~d}, J=$ $21.08 \mathrm{~Hz}), 53.23,51.28,23.13,11.77 .{ }^{19} \mathrm{~F}$ NMR $\left(282 \mathrm{MHz}, \mathrm{CDCl}_{3}\right): \delta-117.63$. HRMSESI $(m / z)[M+H]^{+}$calcd for $\mathrm{C}_{10} \mathrm{H}_{15} \mathrm{NF}, 168.1188$; found 168.1173 .

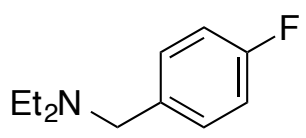

16

In a glovebox, $\mathrm{Cu}(\mathrm{OTf})_{2}(253 \mathrm{mg}, 0.7 \mathrm{mmol}, 4$ equiv) was added to a $8 \mathrm{ml}$ vial containing TBAT (189 mg, 0.35mmol, 2 equiv) and dissolved in MeCN to form a $0.083 \mathrm{M}$ solution. The solution was stirred for $10 \mathrm{~min}$ at $23{ }^{\circ} \mathrm{C}$ after which [4(diethylaminomethyl)phenyl]tributylstannane $(80 \mathrm{mg}, 0.177 \mathrm{mmol}, 1$ equiv) was added. The vial was sealed with a teflon cap, removed from the glovebox and stirred for an additional $3 \mathrm{~h}$ at $60{ }^{\circ} \mathrm{C}$. The mixture was diluted with $8 \mathrm{ml}$ of $\mathrm{Et}_{2} \mathrm{O}$ and washed with $3 \times 5 \mathrm{ml}$ of $1 \mathrm{~N} \mathrm{HCl}$. The aqueous phase was brought to a $\mathrm{pH}$ of 10 and extracted with $3 \times 10 \mathrm{ml}$ of DCM. The organic layer was dried over $\mathrm{Na}_{2} \mathrm{SO}_{4}$, concentrated in vacuo. The identity of the product was confirmed by ${ }^{19} \mathrm{~F}$ NMR spectroscopic analysis to the fully characterized reference, $N, N$-diethyl-(4-fluorobenzyl)amine, on S6.

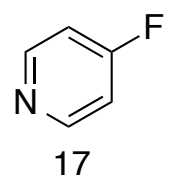

Following general procedure $\mathrm{A}$, with the exception of heating the reaction to $80{ }^{\circ} \mathrm{C}$, 4-fluoropyridine was synthesized in $28 \%$ yield from 4-tributylstannanylpyridine. The mixture was then diluted with $0.5 \mathrm{ml}$ of $\mathrm{MeCN}$ and $0.3 \mathrm{~g}$ of poly-4-vinyl pyridine was added and the mixture was stirred overnight. The yield was determined by ${ }^{19} \mathrm{~F}$ NMR spectroscopic analysis. NMR Spectroscopy: ${ }^{19} \mathrm{~F}$ NMR $\left(282 \mathrm{MHz}, \mathrm{CD}_{3} \mathrm{CN}\right): \delta-$ 
104.85. The ${ }^{19} \mathrm{~F}$ NMR spectroscopic data match NMR data for 4-fluoropyridine previously reported in the literature. ${ }^{4}$

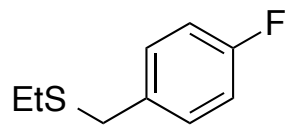

18

In a glovebox, $\mathrm{Cu}(\mathrm{OTf})_{2}(0.075 \mathrm{mmol}, 27 \mathrm{mg}, 3.0$ equiv $)$ was added to a vial containing TBAT (0.075 mmol, $40.5 \mathrm{mg}, 3.0$ equiv) and MeCN (300 $\mu \mathrm{l})$. The vial was sealed with a teflon cap, removed from the glovebox and stirred for $10 \mathrm{~min}$ at $60{ }^{\circ} \mathrm{C}$. After $10 \mathrm{~min}$ [4-(ethyl-methylenesulfide)phenyl]tributylstannane (0.025 mmol, 1.0 equiv) was added and the reaction was stirred at $60{ }^{\circ} \mathrm{C}$ for $3 \mathrm{~h}$ and subsequently cooled to $23{ }^{\circ} \mathrm{C}$. To the reaction mixture was added 1-fluoro-3-nitrobenzene (3.0 $\mu$, $0.0282 \mathrm{mmol})$ as the internal standard and MeCN or DCM (0.5 ml). The resulting solution was analyzed by ${ }^{19}$ F NMR spectroscopy. A yield of 37\% was determined by comparing the integration of the ${ }^{19} \mathrm{~F}$ NMR resonance of Ethyl 4-fluorobenzyl sulfide (-118.02 ppm, previously synthesized and characterized on S7) with that of 1fluoro-3-nitrobenzene (-112.0 ppm). Product identification was further confirmed via ${ }^{19} \mathrm{~F}$ NMR spectroscopy by spiking the crude product mixture with the reference compound and by matching the analytical HPLC retention time of both the crude product mixture and the reference compound. ${ }^{19} \mathrm{~F} \mathrm{NMR}\left(282 \mathrm{MHz}, \mathrm{CH}_{3} \mathrm{CN}\right): \delta$ 118.02 .

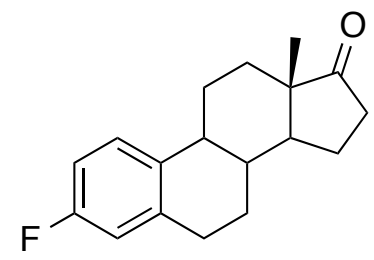

19

Following general procedure B, 3-deoxy-3-fluoroestrone was synthesized from 3deoxy-3-(tributylstannyl)estrone ${ }^{1}$ in 76\% yield, $25 \mathrm{mg}$ was isolated as a white solid using preparative TLC with $10 \%$ EtOAc/Hexane as the eluent. The ${ }^{1} \mathrm{H},{ }^{13} \mathrm{C}$ and ${ }^{19} \mathrm{~F}$ 
NMR spectroscopic data of the purified material correctly match data previously reported. ${ }^{1}$

\section{References:}

1. Tang, P.; Furuya, T.; Ritter, T., Silver-Catalyzed Late-Stage Fluorination. J. Am. Chem. Soc. 2010, 132, 12150-12154.

2. Kim, A.; Powers, J. D.; Toczko, J. F., Novel Synthesis of Desymmetrized Resorcinol Derivatives: Aryl Fluoride Displacement on Deactivated Substrates. J. Org. Chem. 2006, 71, 2170-2172.

3. Ye, Y.; Sanford, M. S., Mild Copper-Mediated Fluorination of Aryl Stannanes and Aryl Trifluoroborates. J. Am. Chem. Soc. 2013, 135, 4648-4651.

4. Ye, Y.; Schimler, S. D.; Hanley, P. S.; Sanford, M. S., Cu(OTf)2-Mediated Fluorination of Aryltrifluoroborates with Potassium Fluoride. J. Am. Chem. Soc. 2013, 135, 16292-16295.

5. $\quad$ Kosugi, M.; Shimizu, K.; Ohtani, A.; Migita, T., Palladium Catalyzed Reaction of Hexabutylditin with Aryl Bromides: Preparation of Negatively Substituted Aryltributyltin. Chem. Lett. 1981, 10, 829-830.

6. Furuya, T.; Strom, A. E.; Ritter, T., Silver-Mediated Fluorination of Functionalized Aryl Stannanes. J. Am. Chem. Soc. 2009, 131, 1662-1663. 
${ }^{1} \mathrm{H}$ NMR

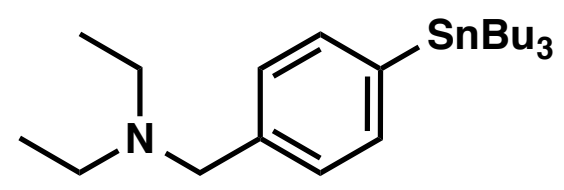

rg-156 $11 \quad 1$ /Users/myrbx200/Desktop/NMR/AV600

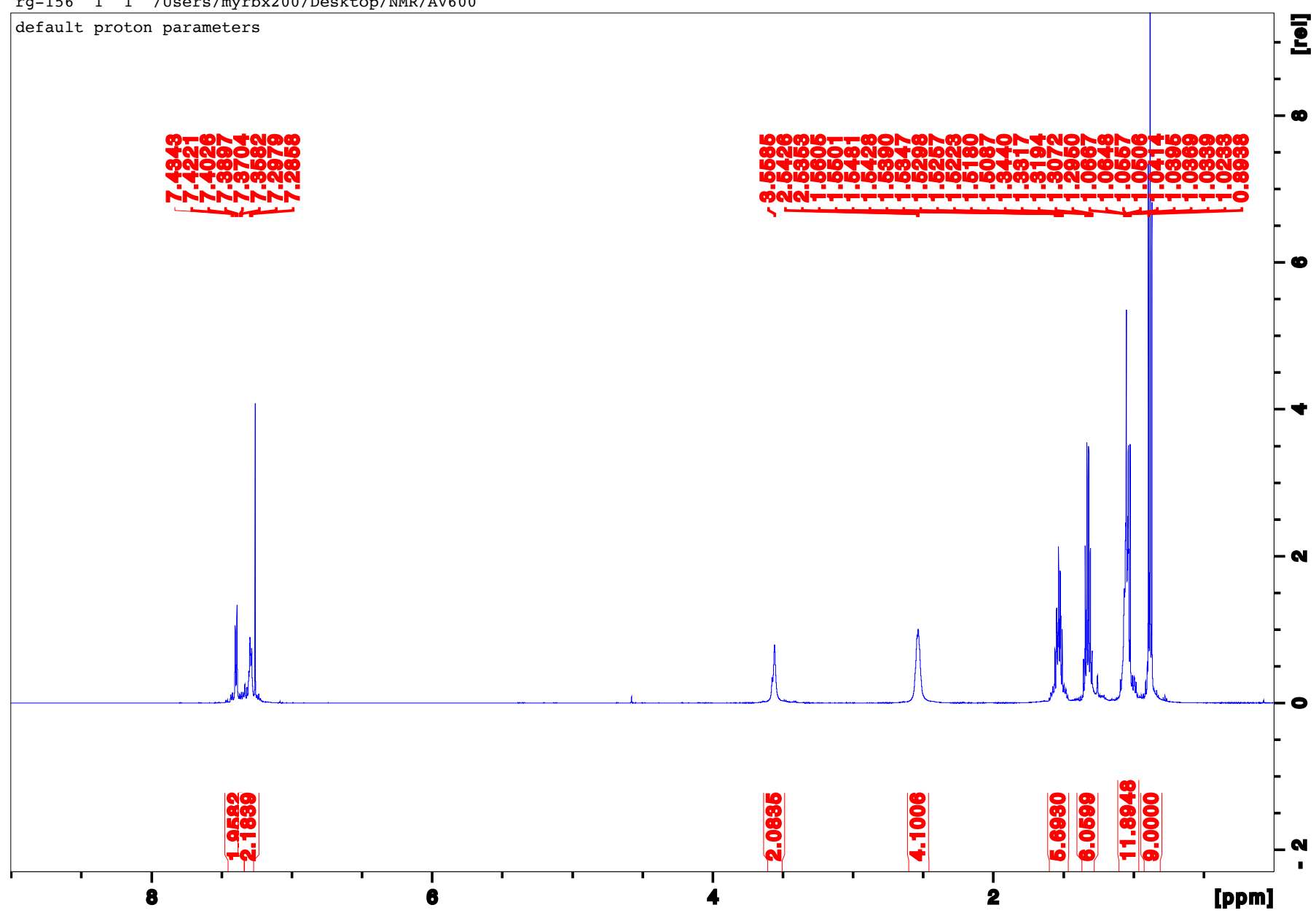


${ }^{13} \mathrm{C}$ NMR
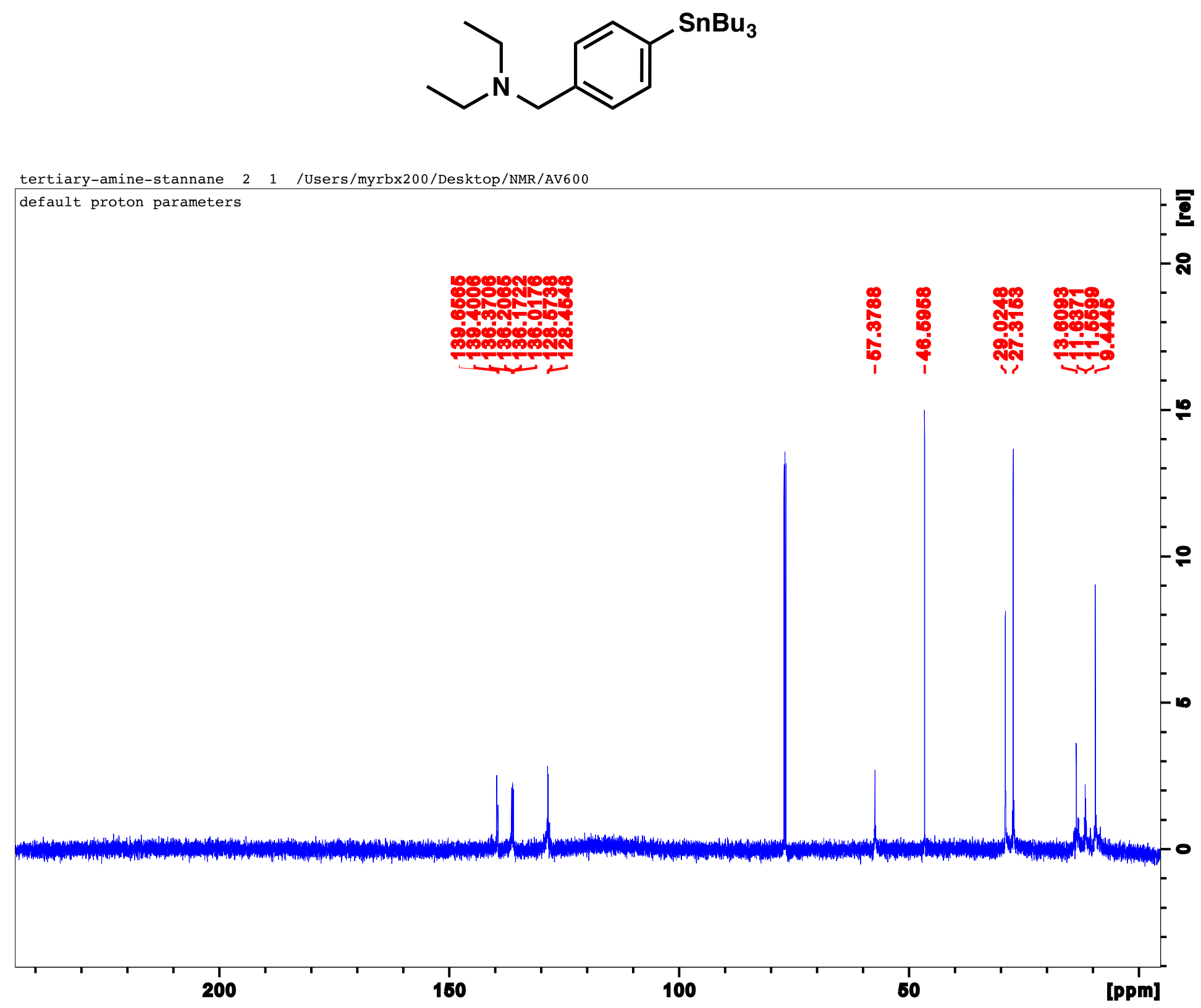
${ }^{1} \mathrm{H}$ NMR

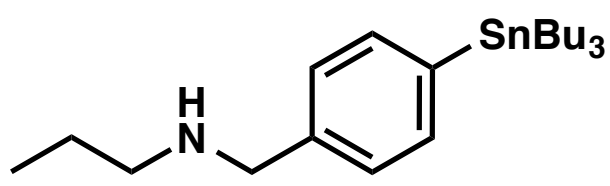

secondary-amine-stannane 11 1 /Users/myrbx200/Desktop/NMR/AV600

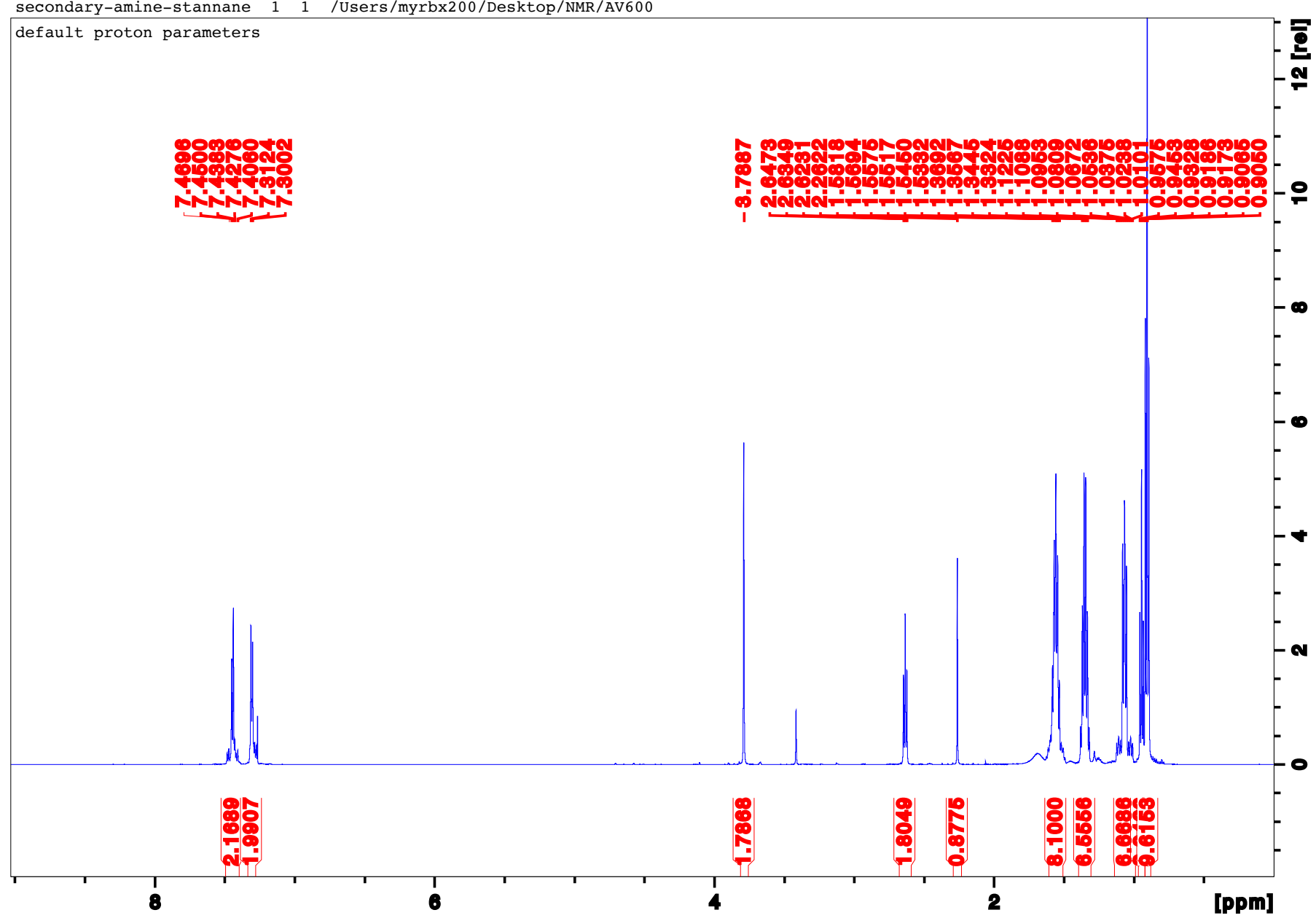


${ }^{13} \mathrm{C}$ NMR

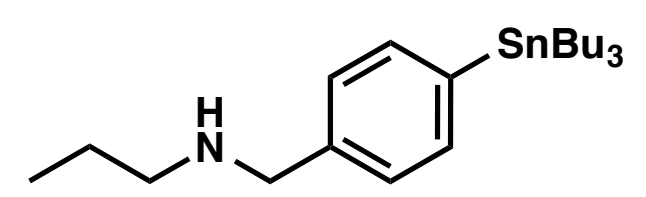

2ndaminestannane-pure2 111 /Users/myrbx200/Desktop/NMR/AV500

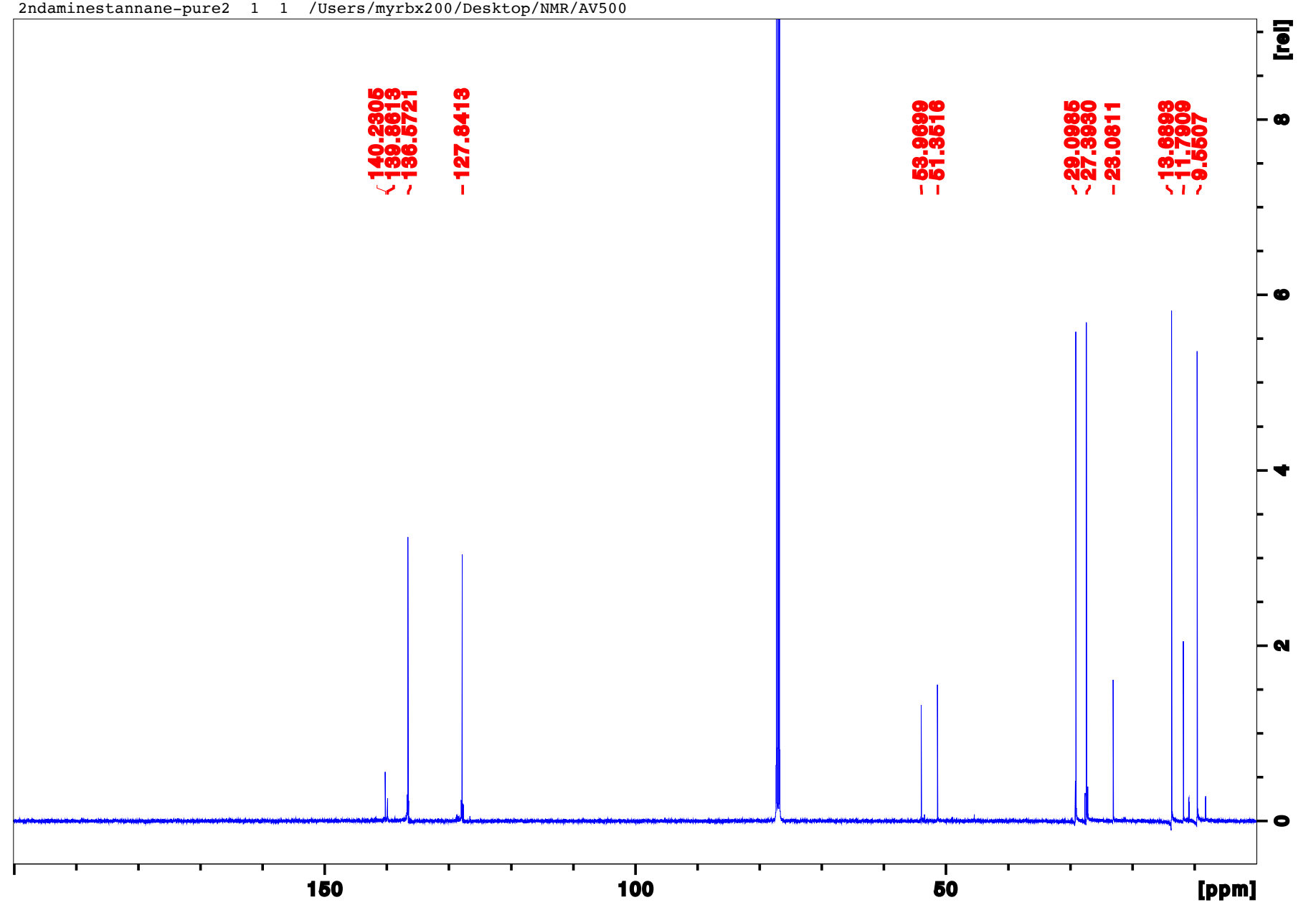


${ }^{1} \mathrm{H}$ NMR

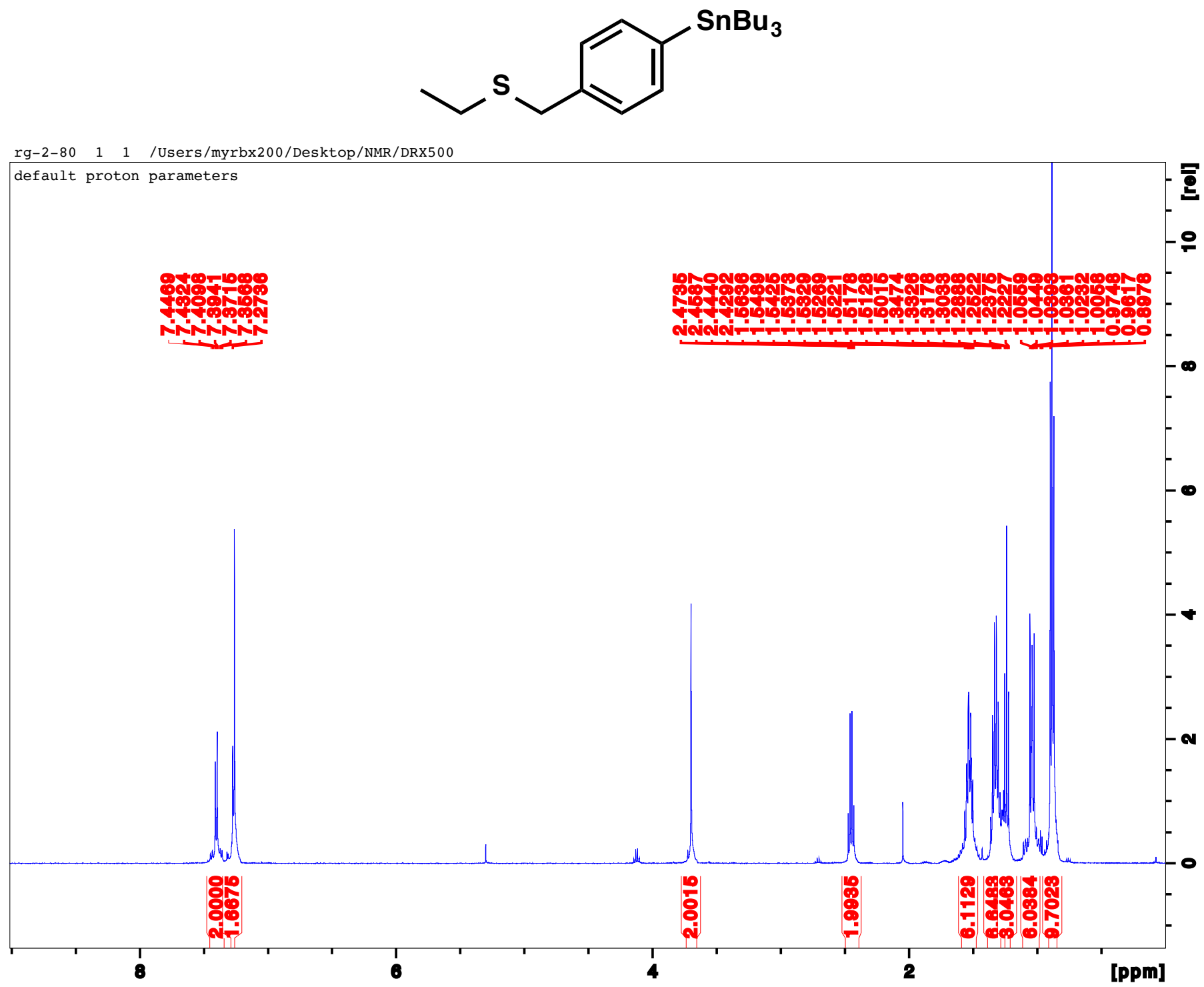


${ }^{13} \mathrm{C}$ NMR
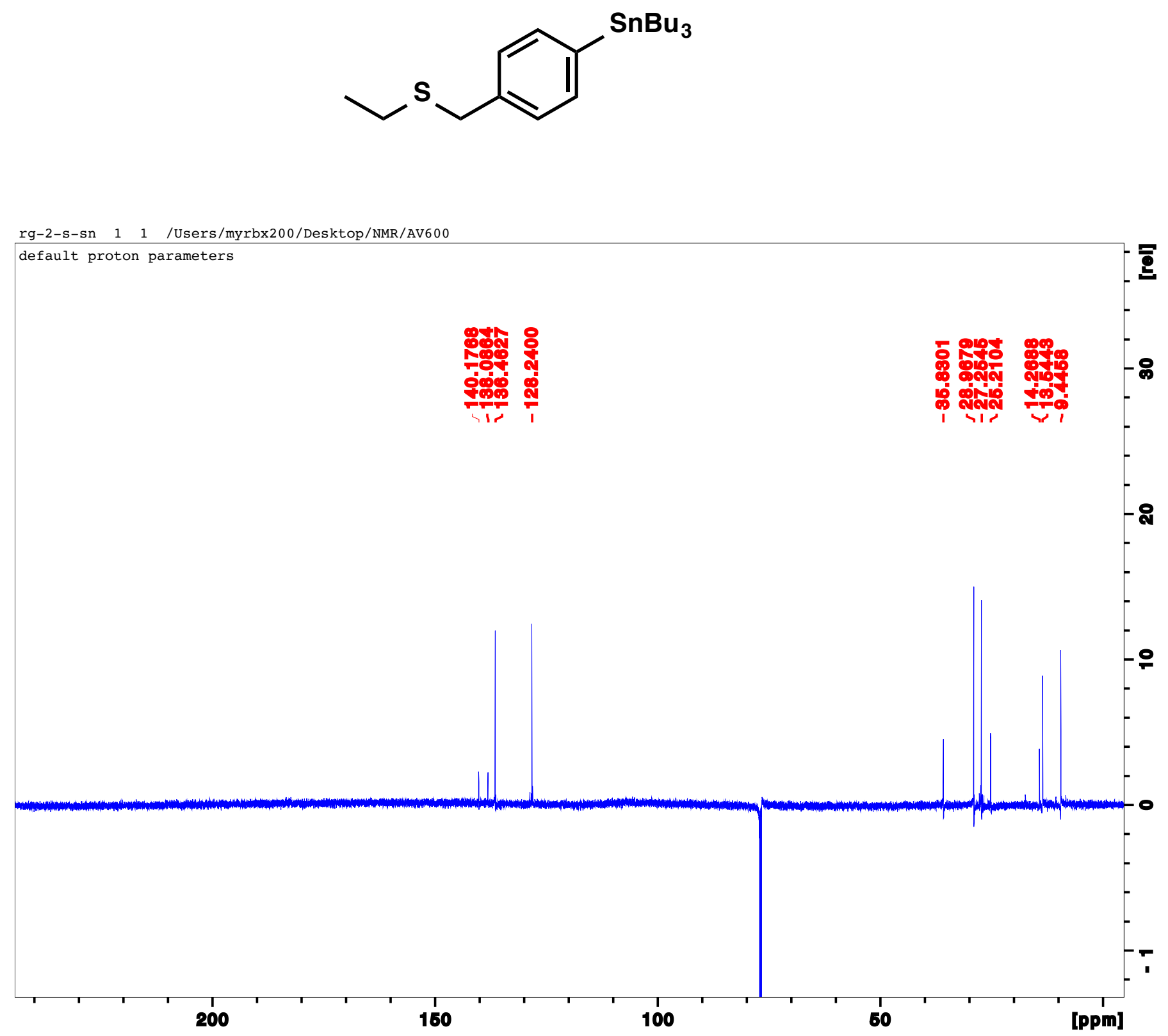
${ }^{1} \mathrm{H}$ NMR
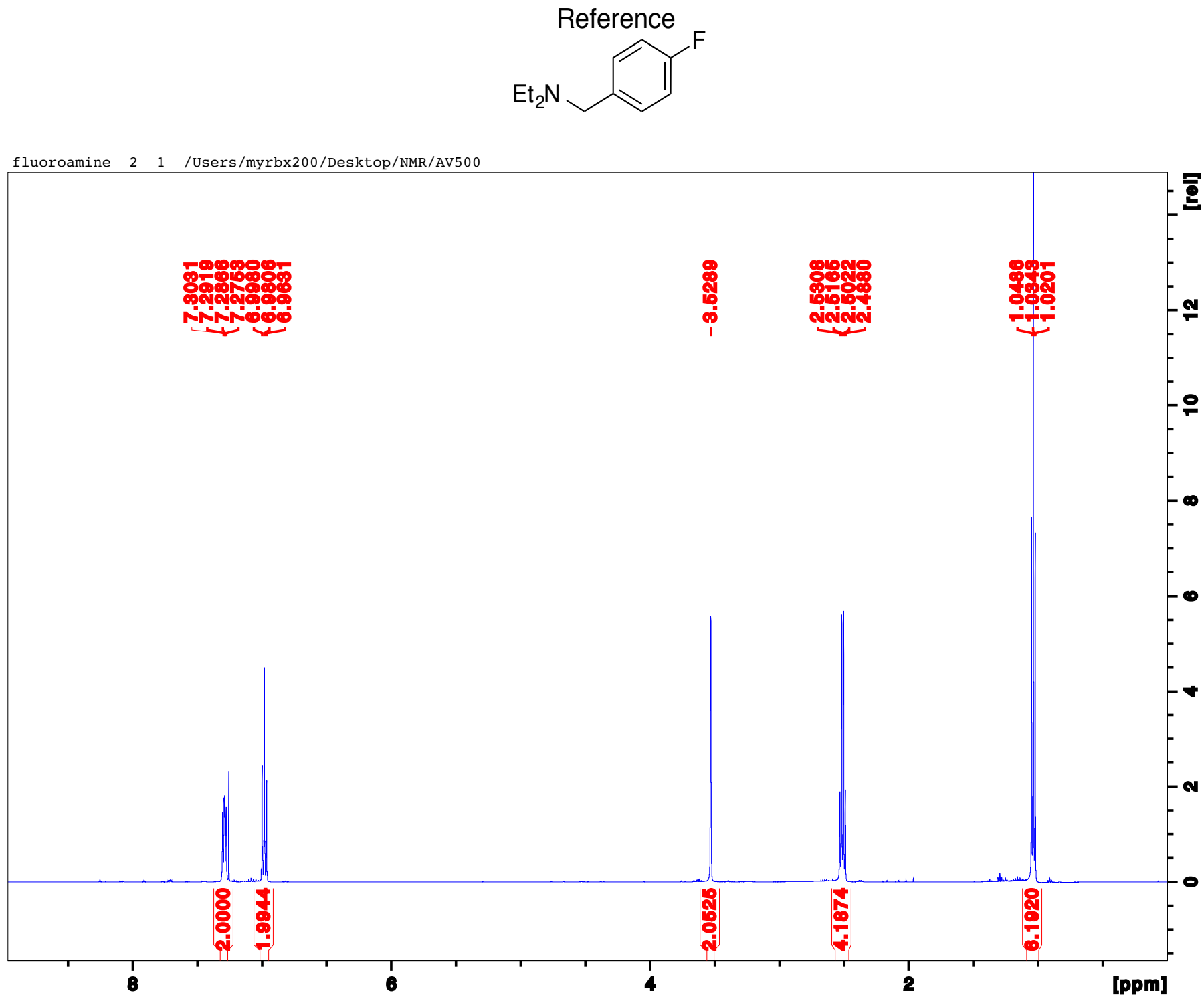


\section{${ }^{13} \mathrm{C}$ NMR}

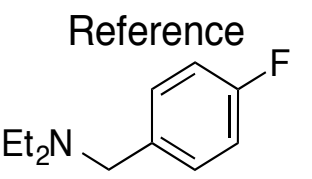

fluoroamine 1 1 /Users/myrbx200/Desktop/NMR/AV500

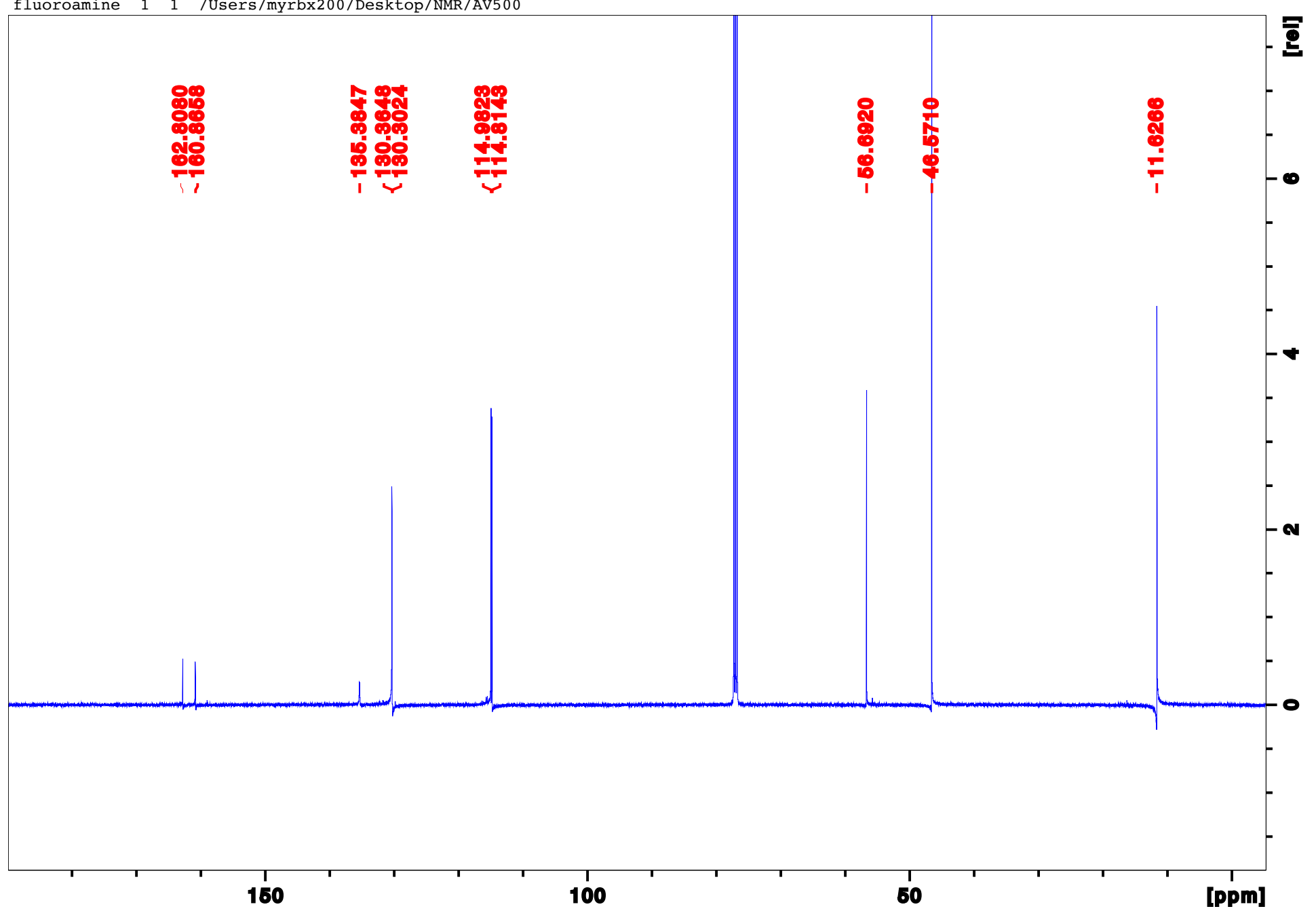




\section{${ }^{19} \mathrm{~F}$ NMR}

\section{Reference}
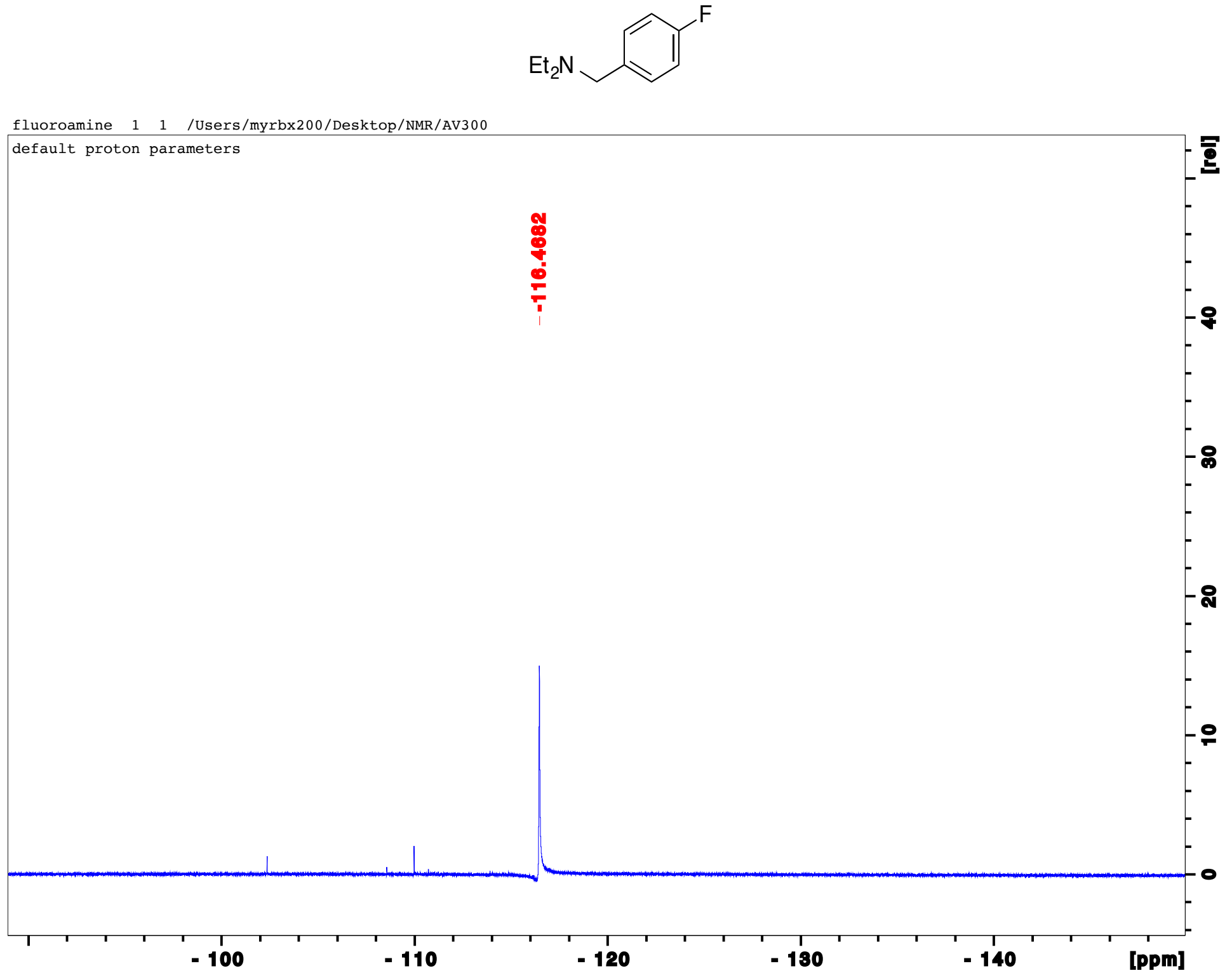
${ }^{1} \mathrm{H}$ NMR
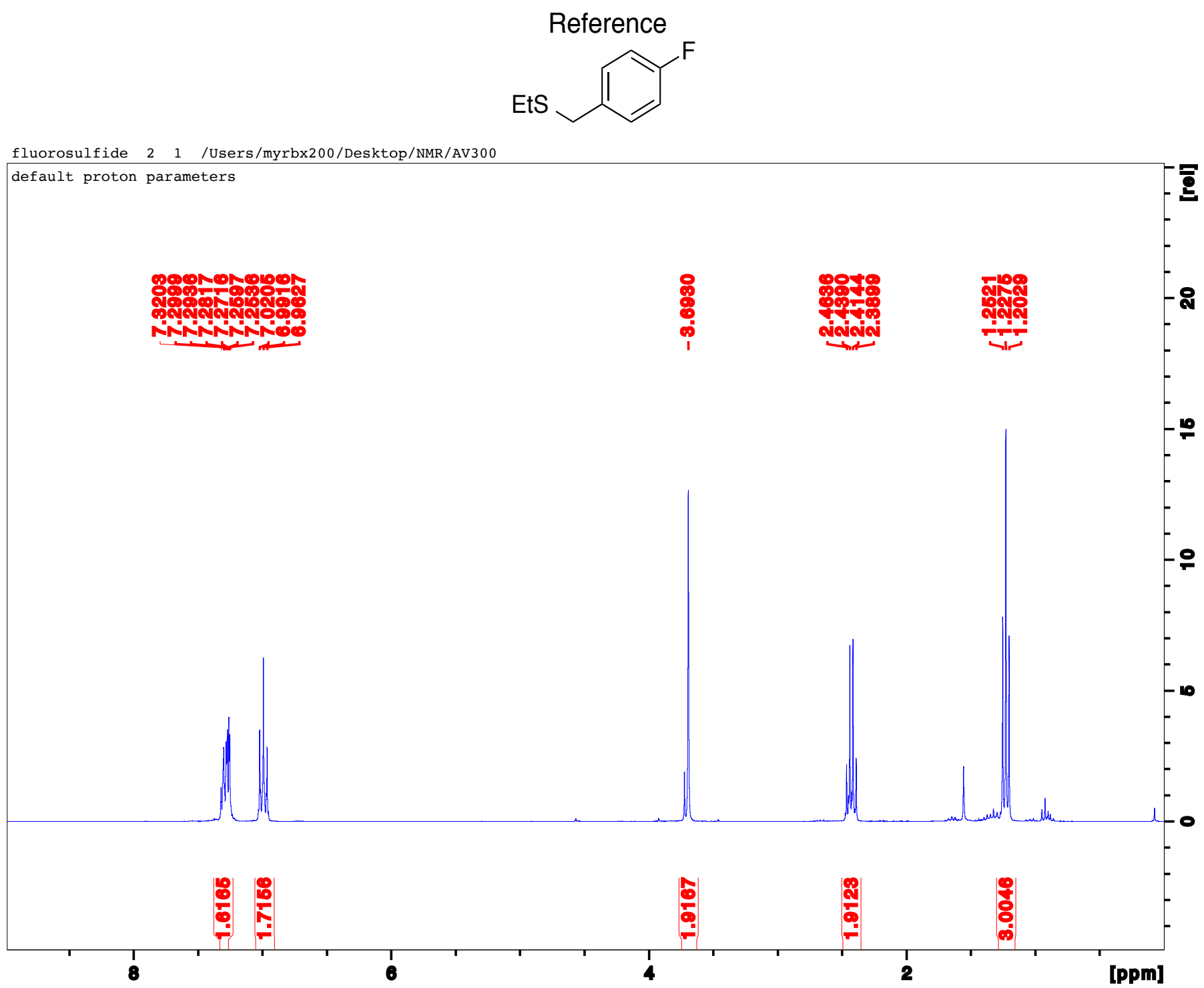


\section{${ }^{13} \mathrm{C}$ NMR}

\section{Reference}

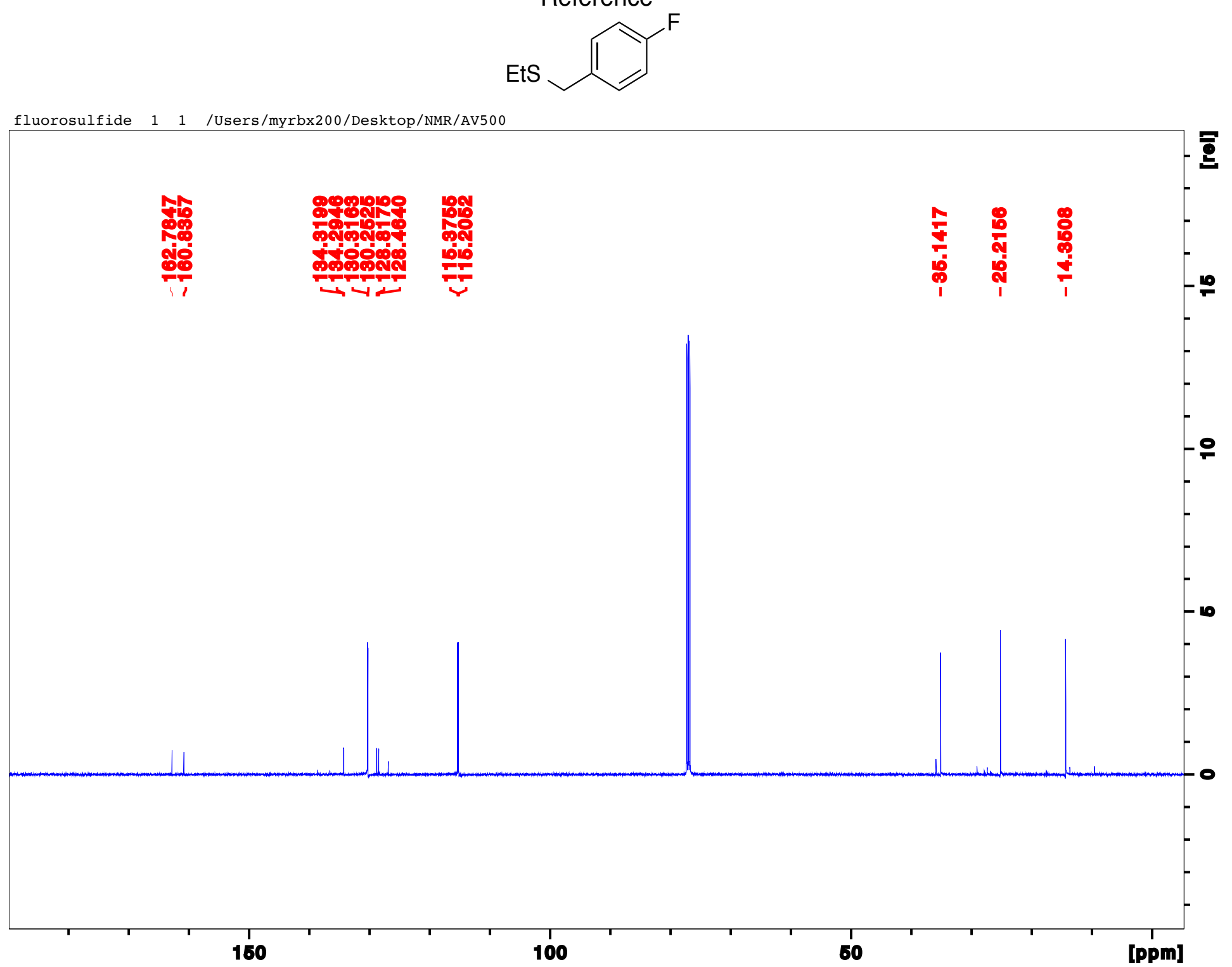




\section{${ }^{19} \mathrm{~F}$ NMR}

\section{Reference}

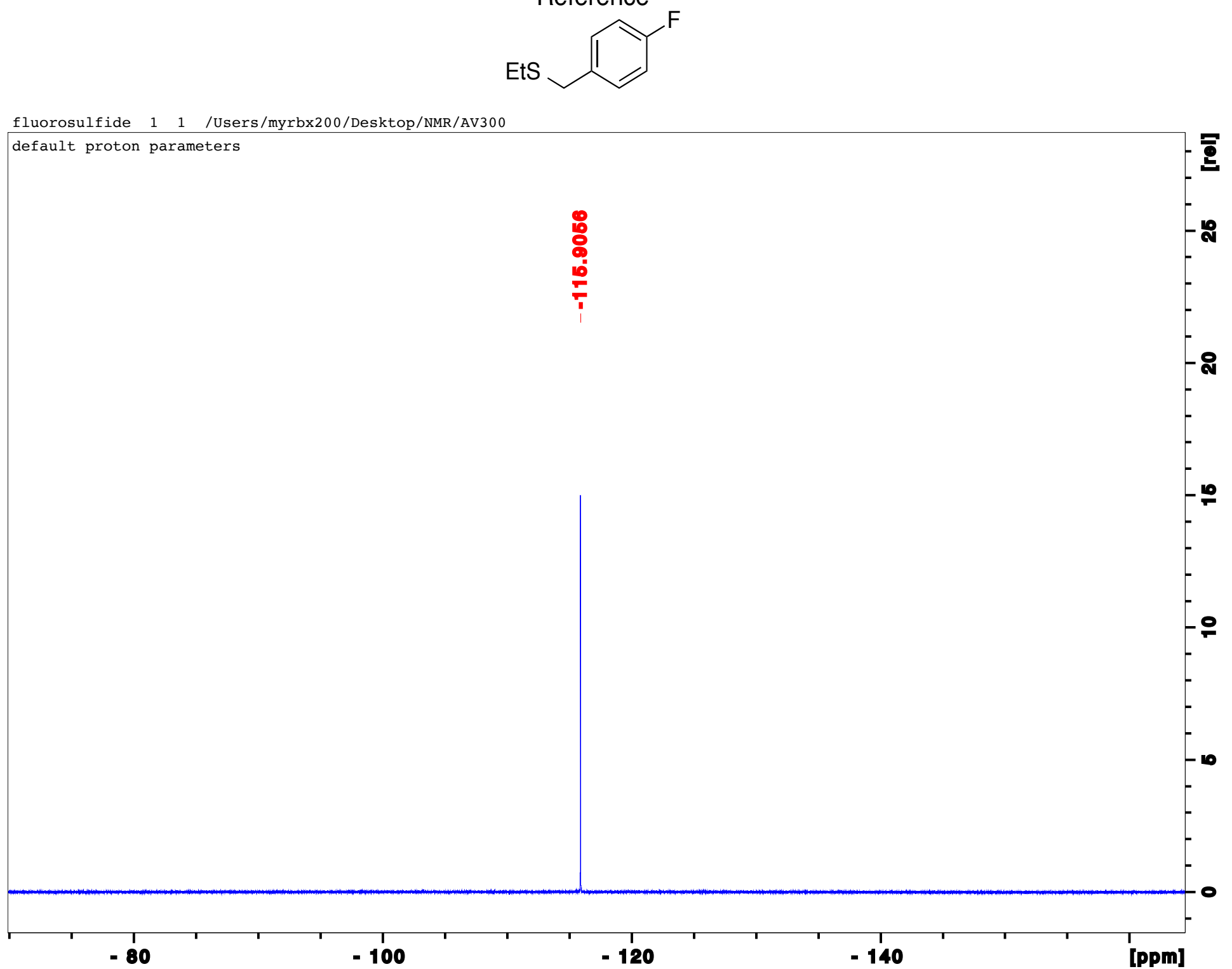


${ }^{1} \mathrm{H}$ NMR

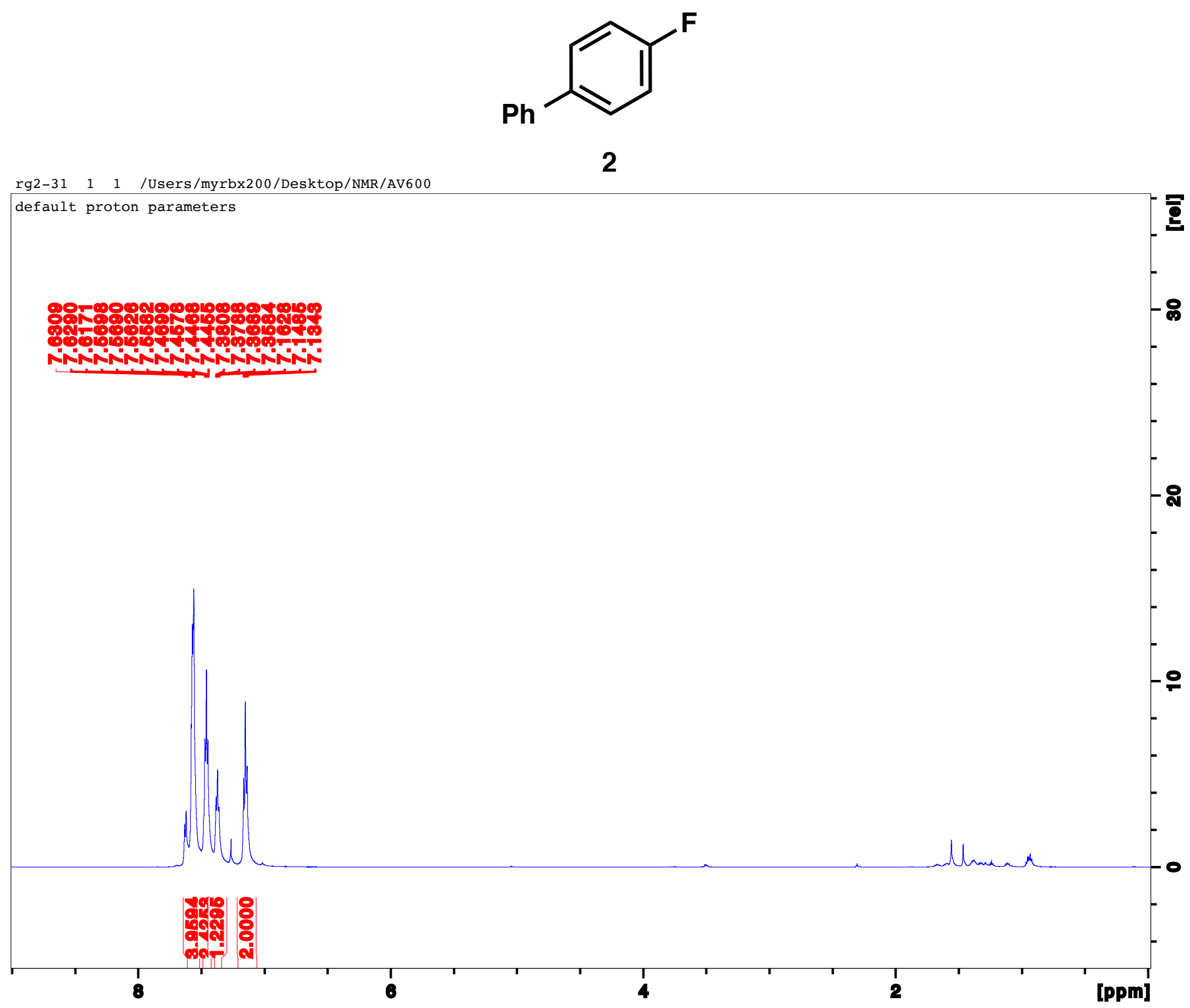


${ }^{13} \mathrm{C}$ NMR

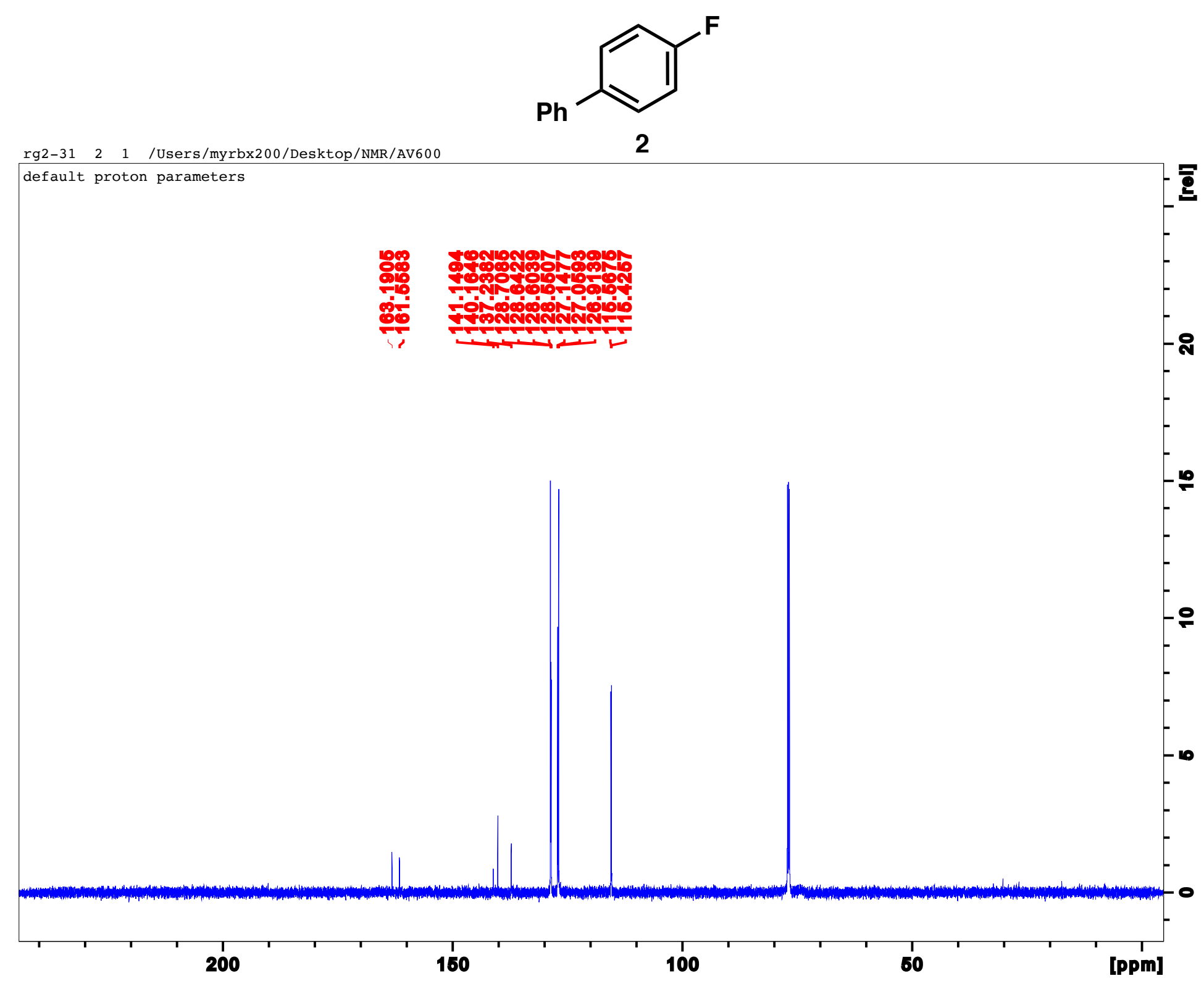


${ }^{19} \mathrm{~F}$ NMR

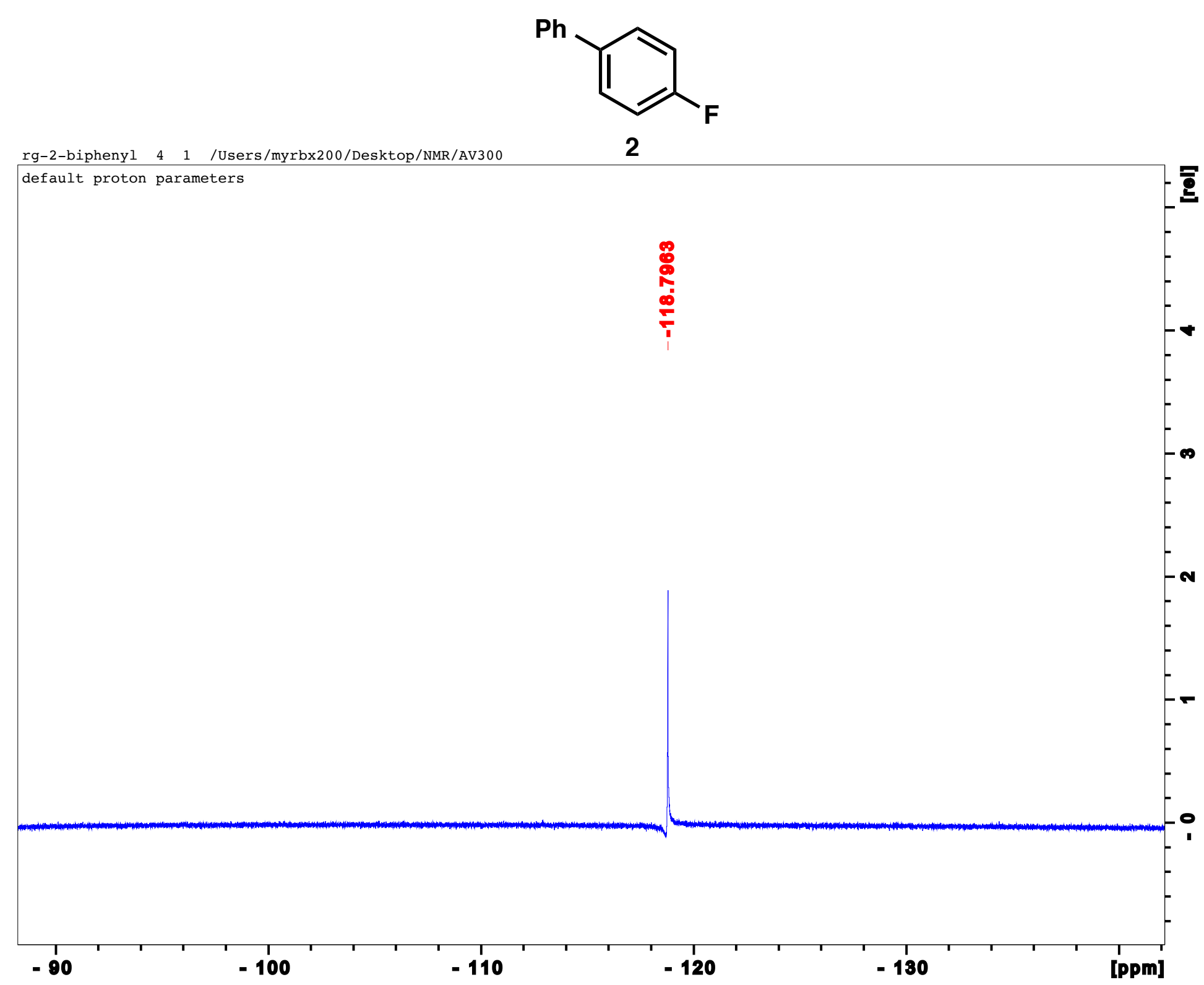


${ }^{1} \mathrm{H}$ NMR

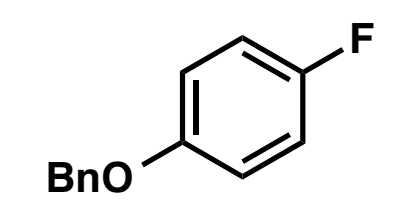

rg2-32 111 /Users/myrbx200/Desktop/NMR/AV600

3

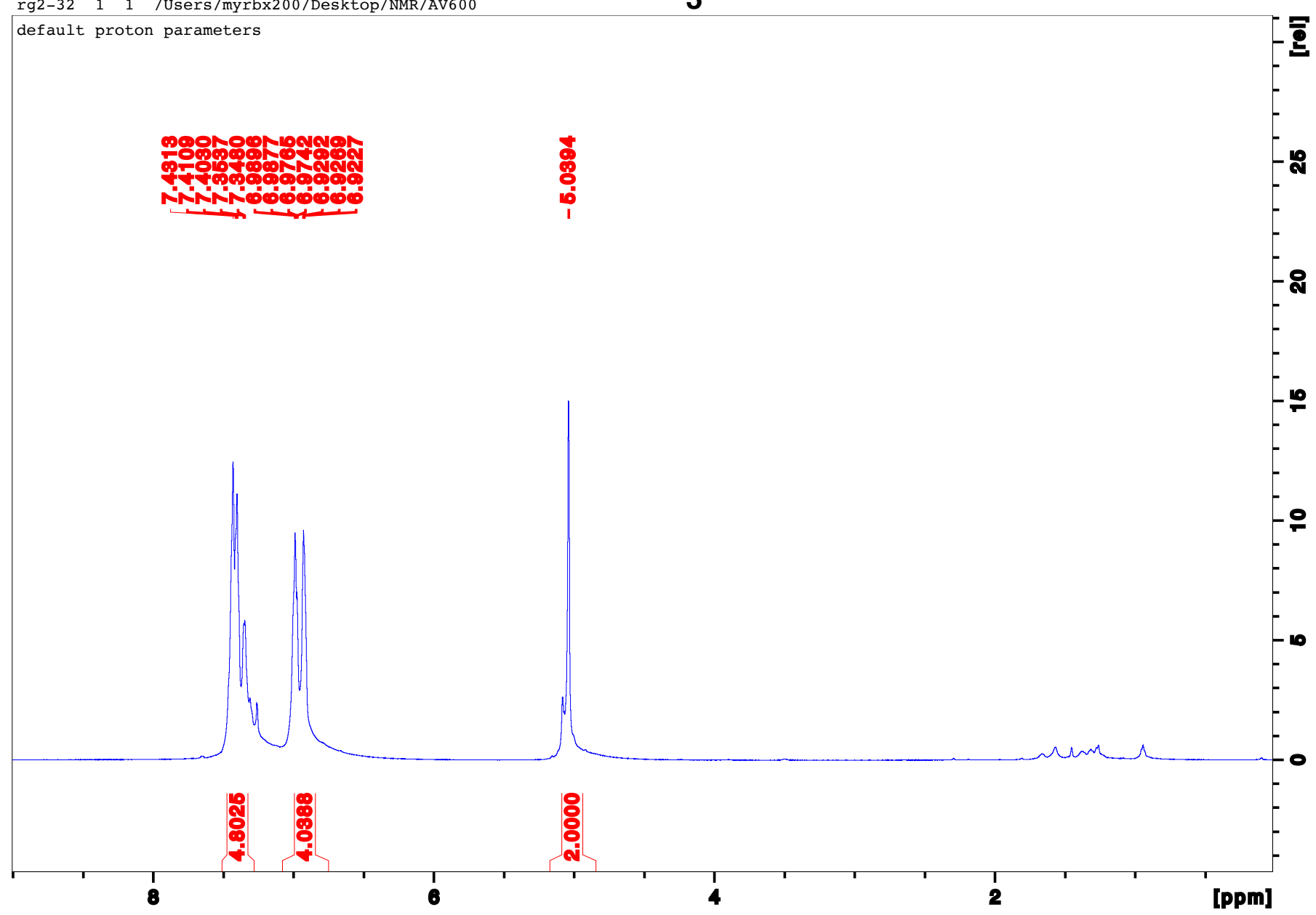


${ }^{13} \mathrm{C}$ NMR

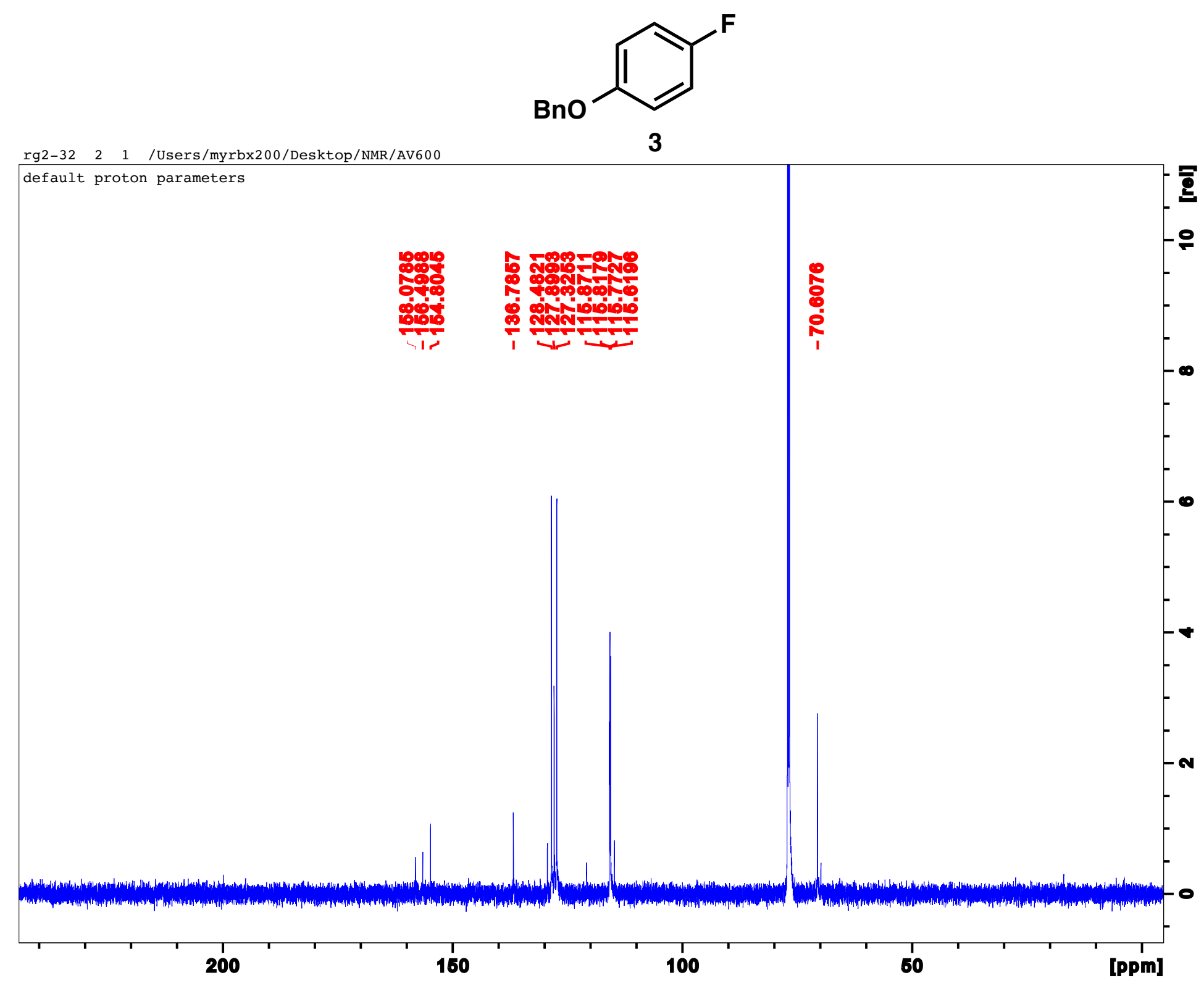


${ }^{19} \mathrm{~F}$ NMR

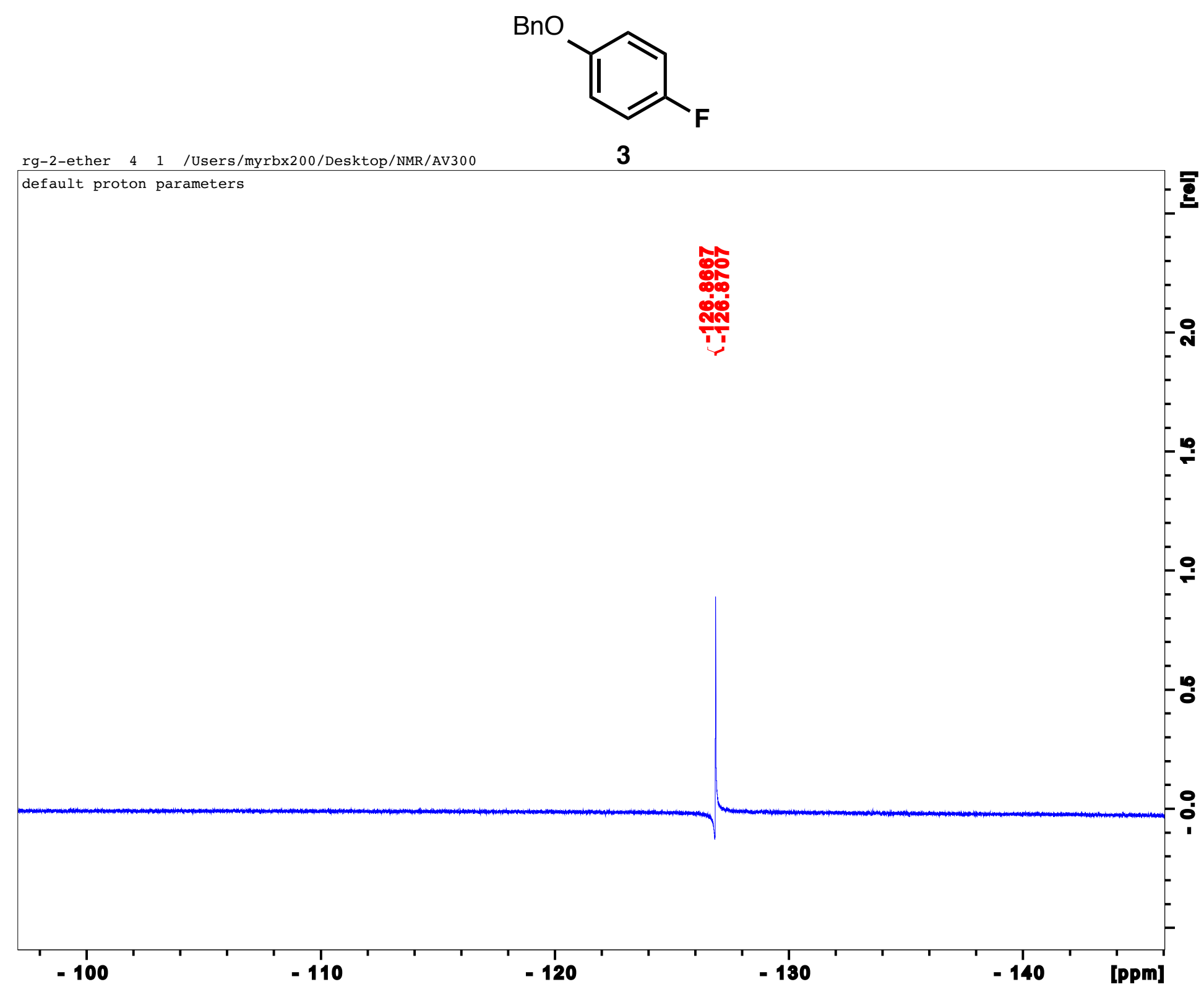


${ }^{19} \mathrm{~F}$ NMR

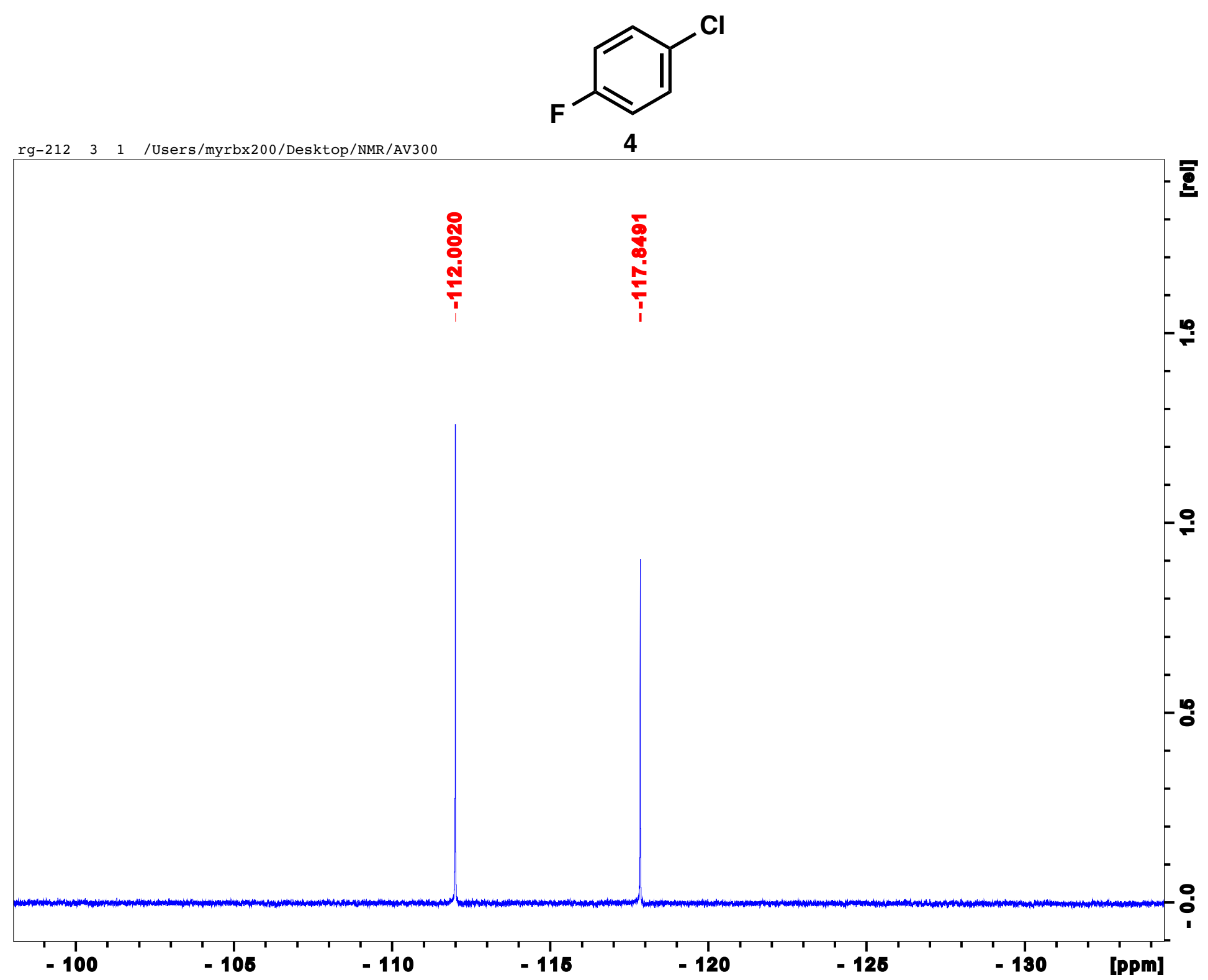


${ }^{19} \mathrm{~F}$ NMR

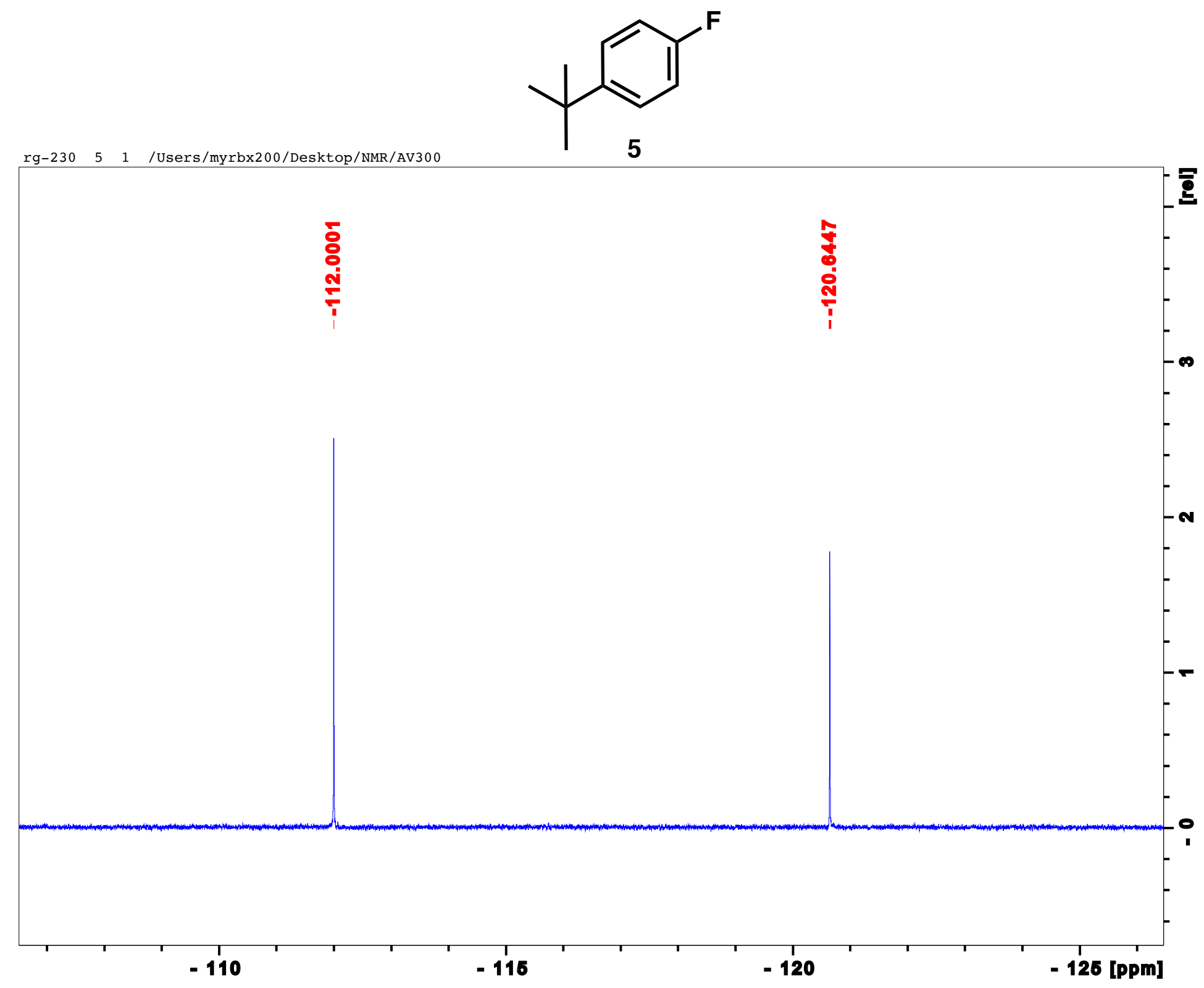


${ }^{1} \mathrm{H}$ NMR
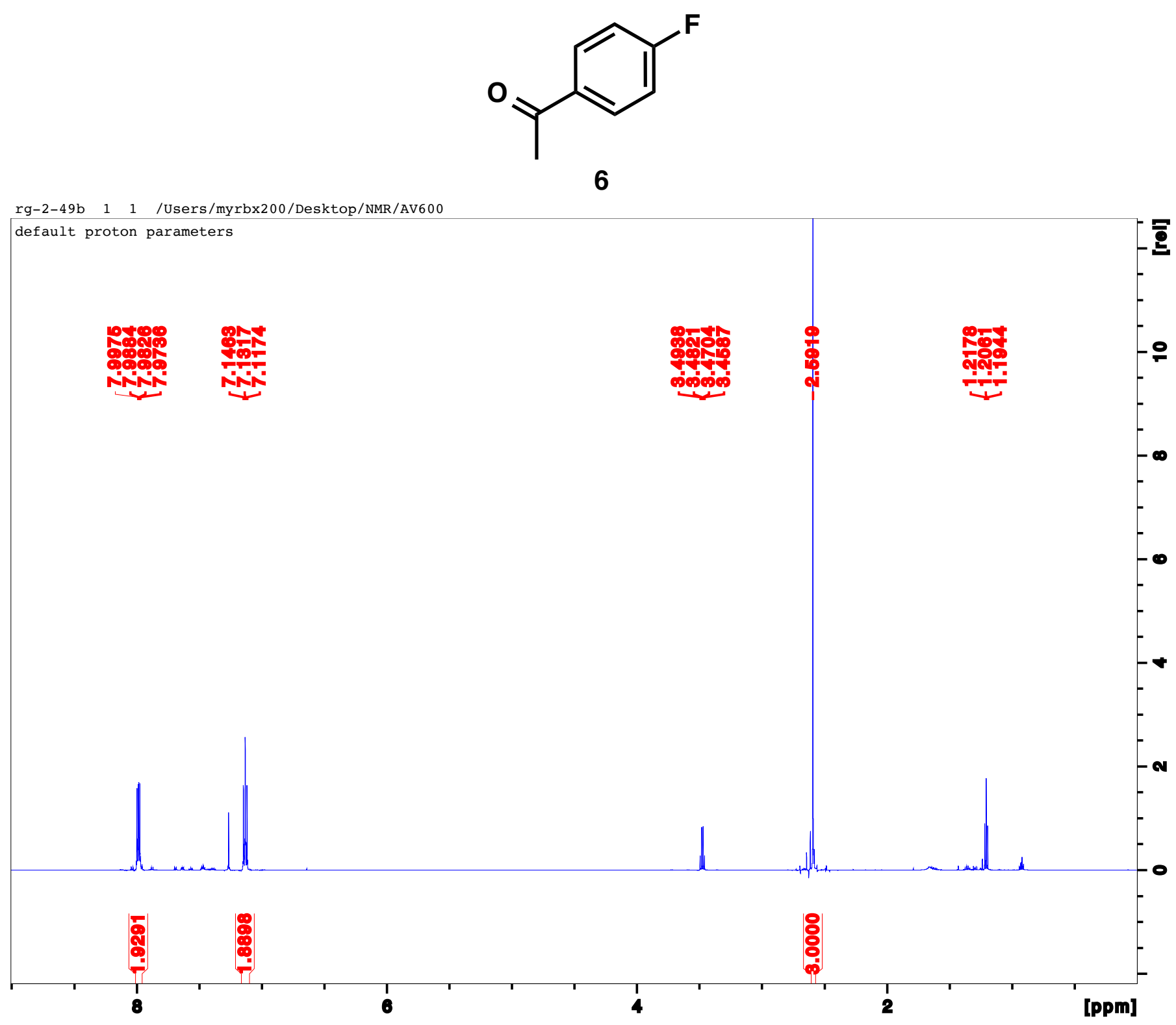
${ }^{13} \mathrm{C}$ NMR

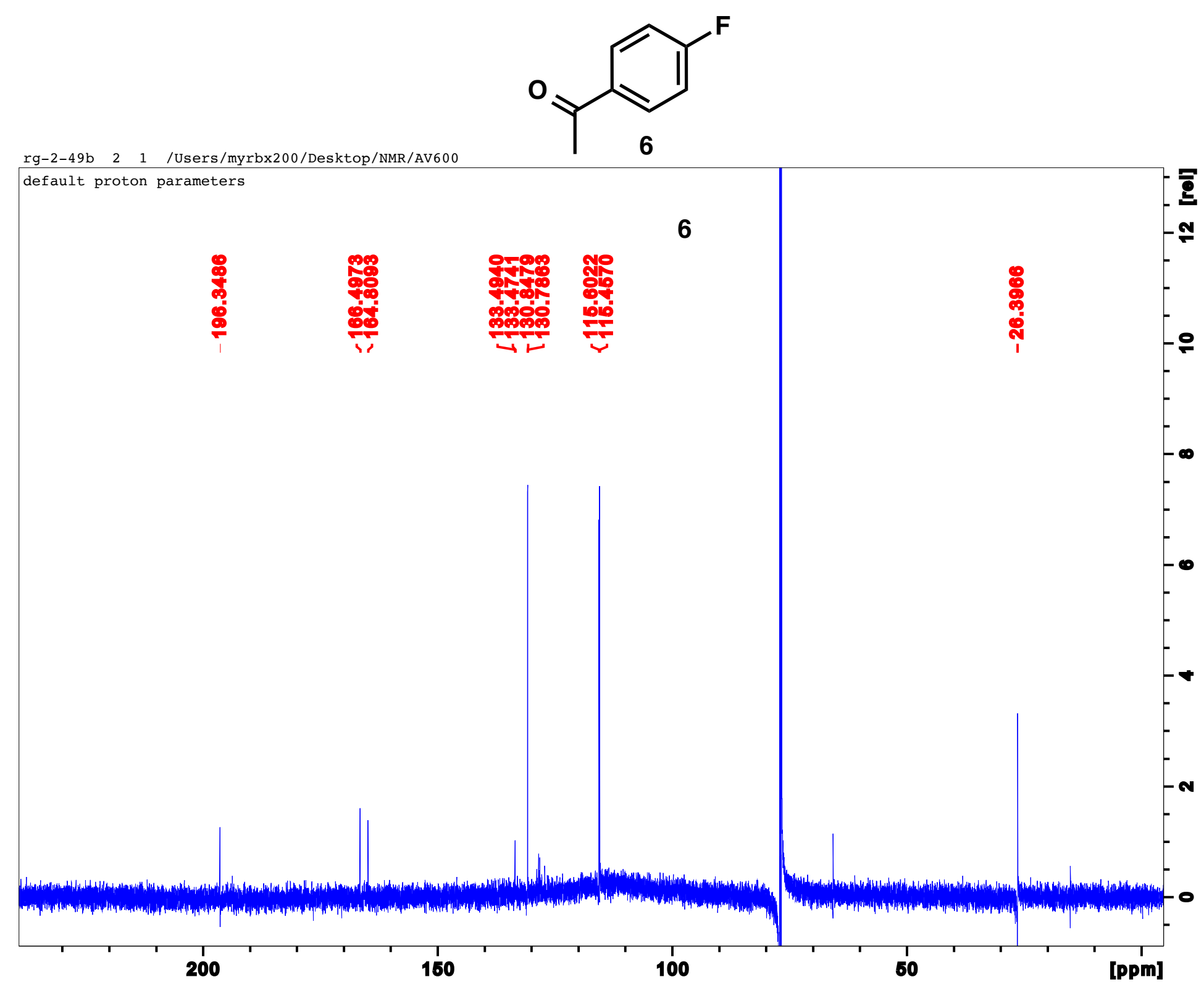


${ }^{19} \mathrm{~F}$ NMR

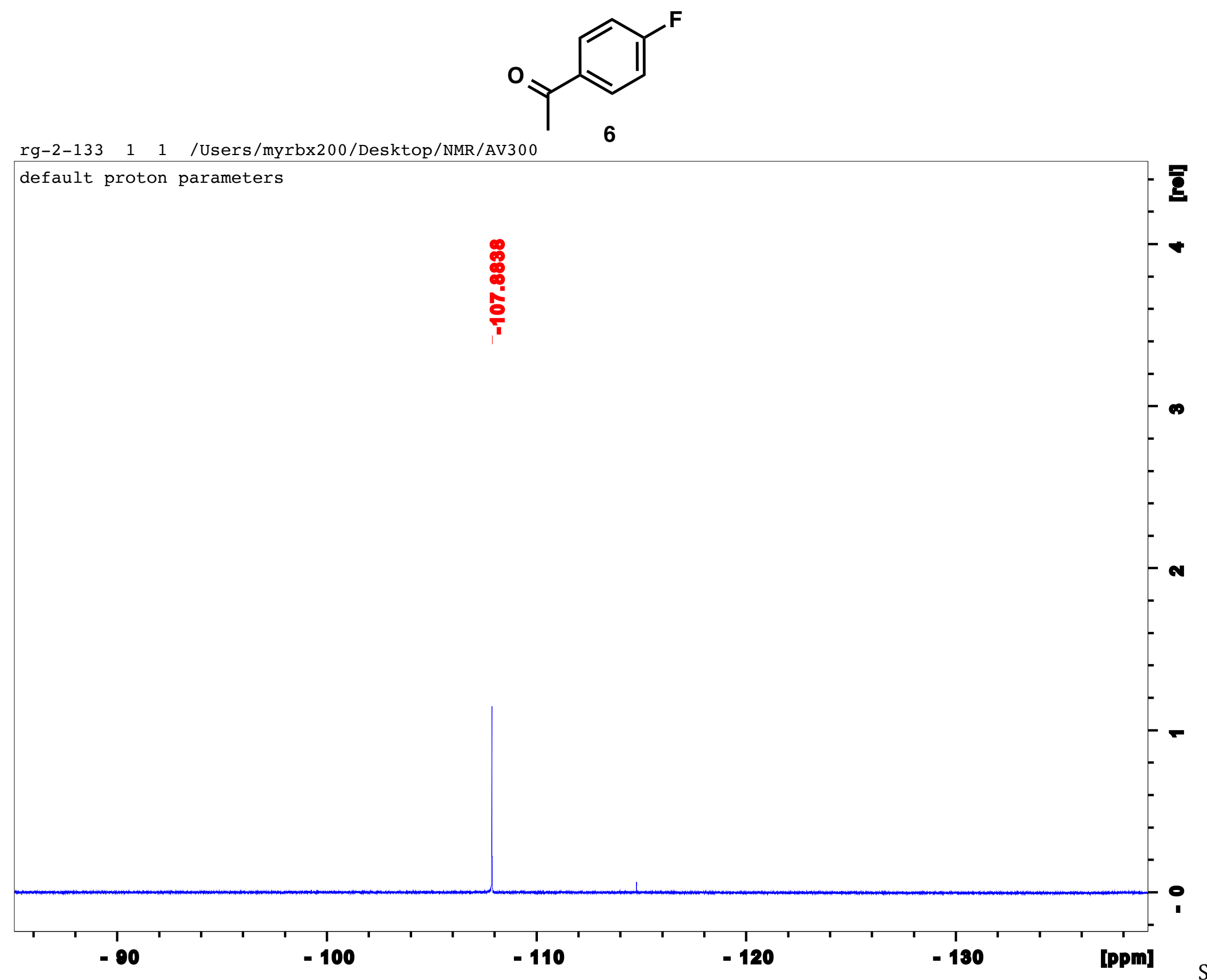


${ }^{1} \mathrm{H}$ NMR
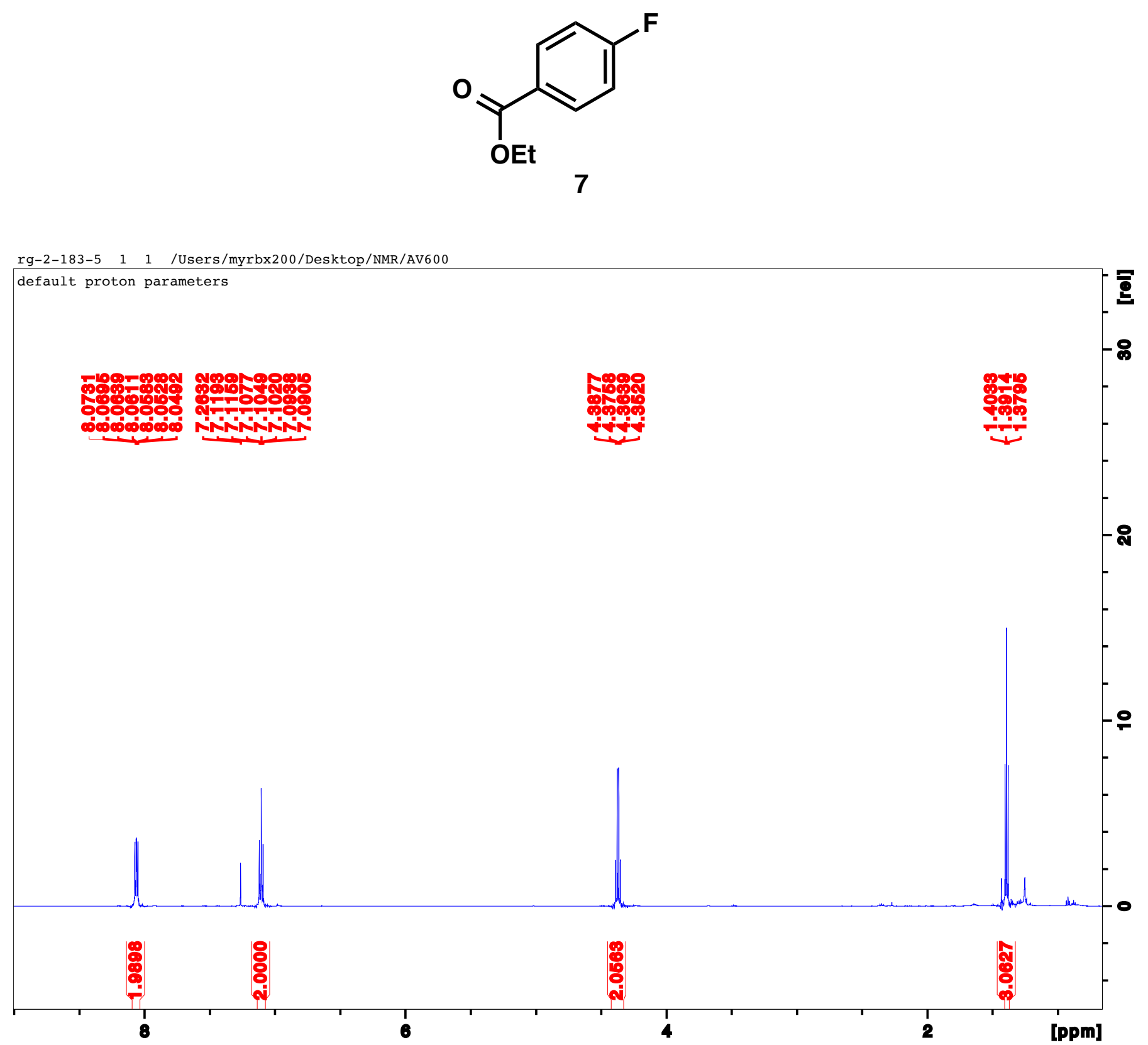
${ }^{13} \mathrm{C}$ NMR

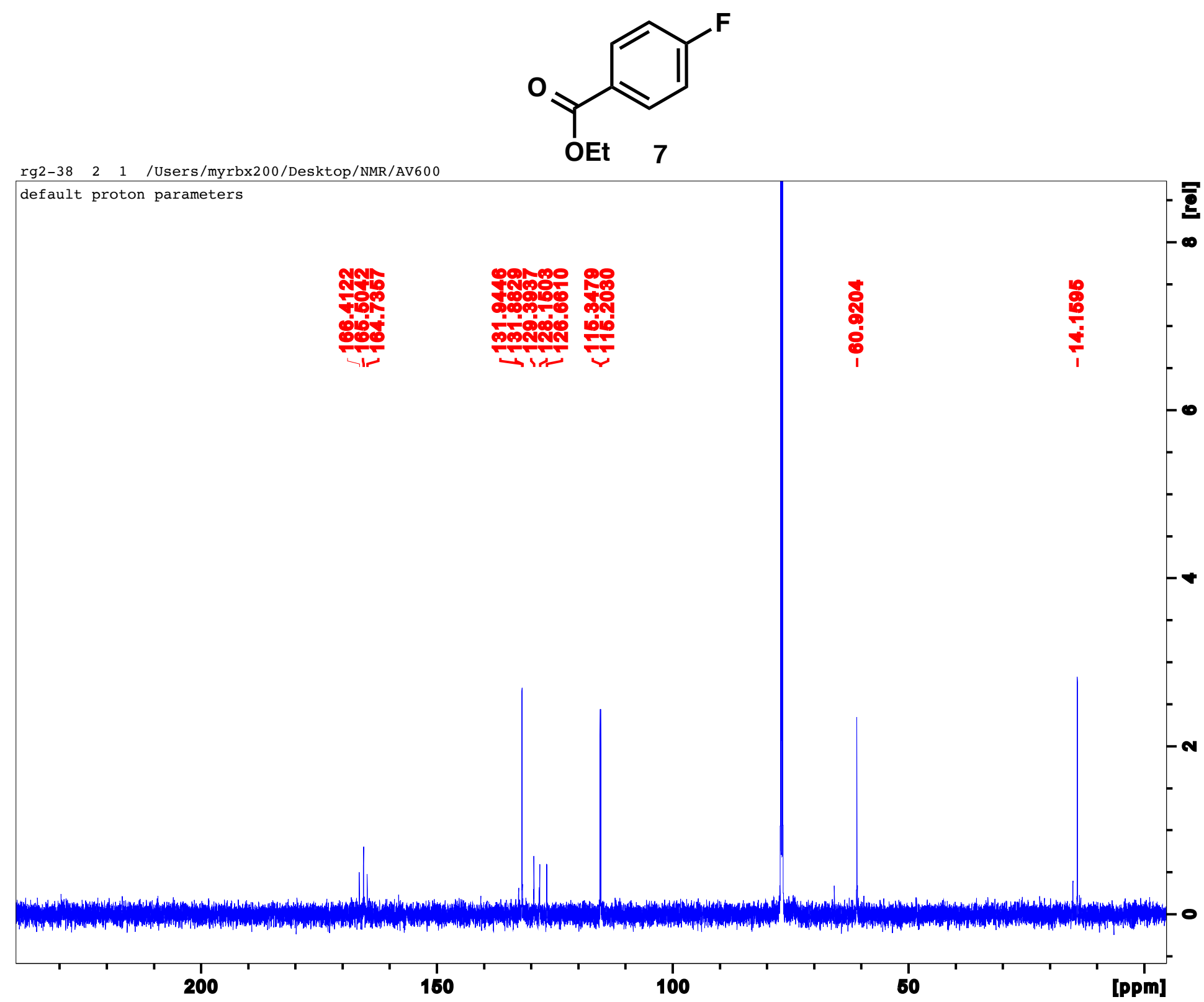




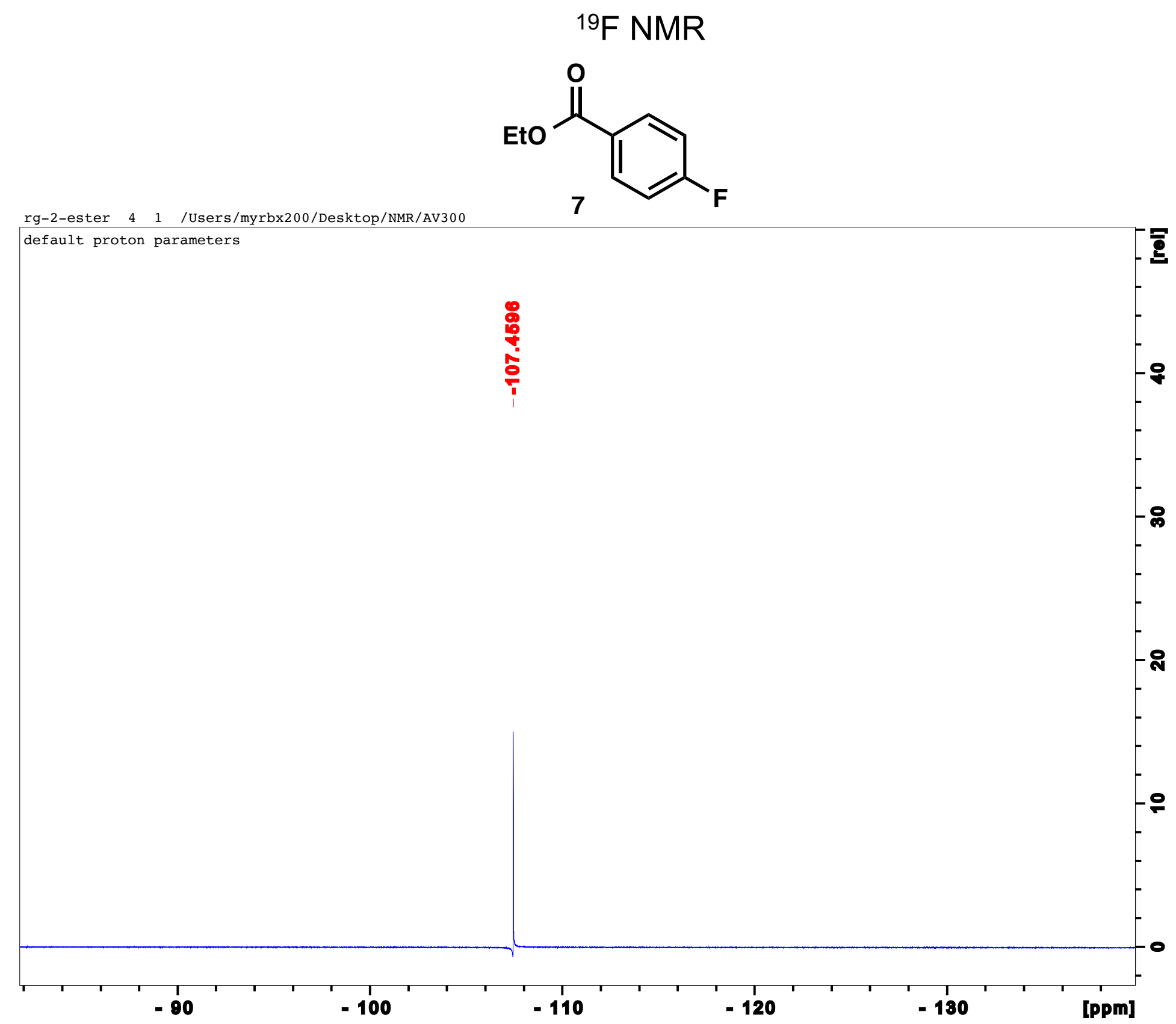


${ }^{1} \mathrm{H}$ NMR

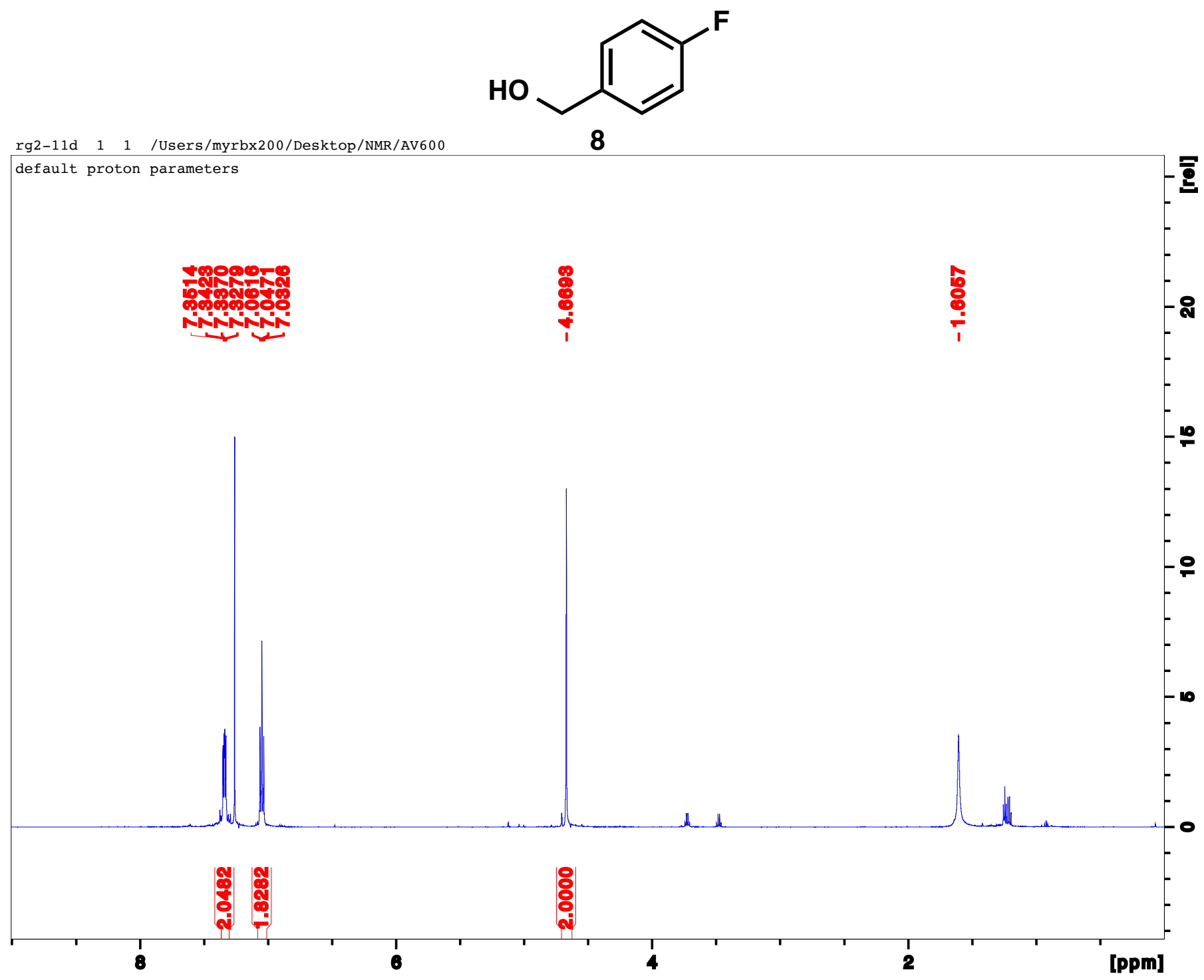


${ }^{13} \mathrm{C}$ NMR

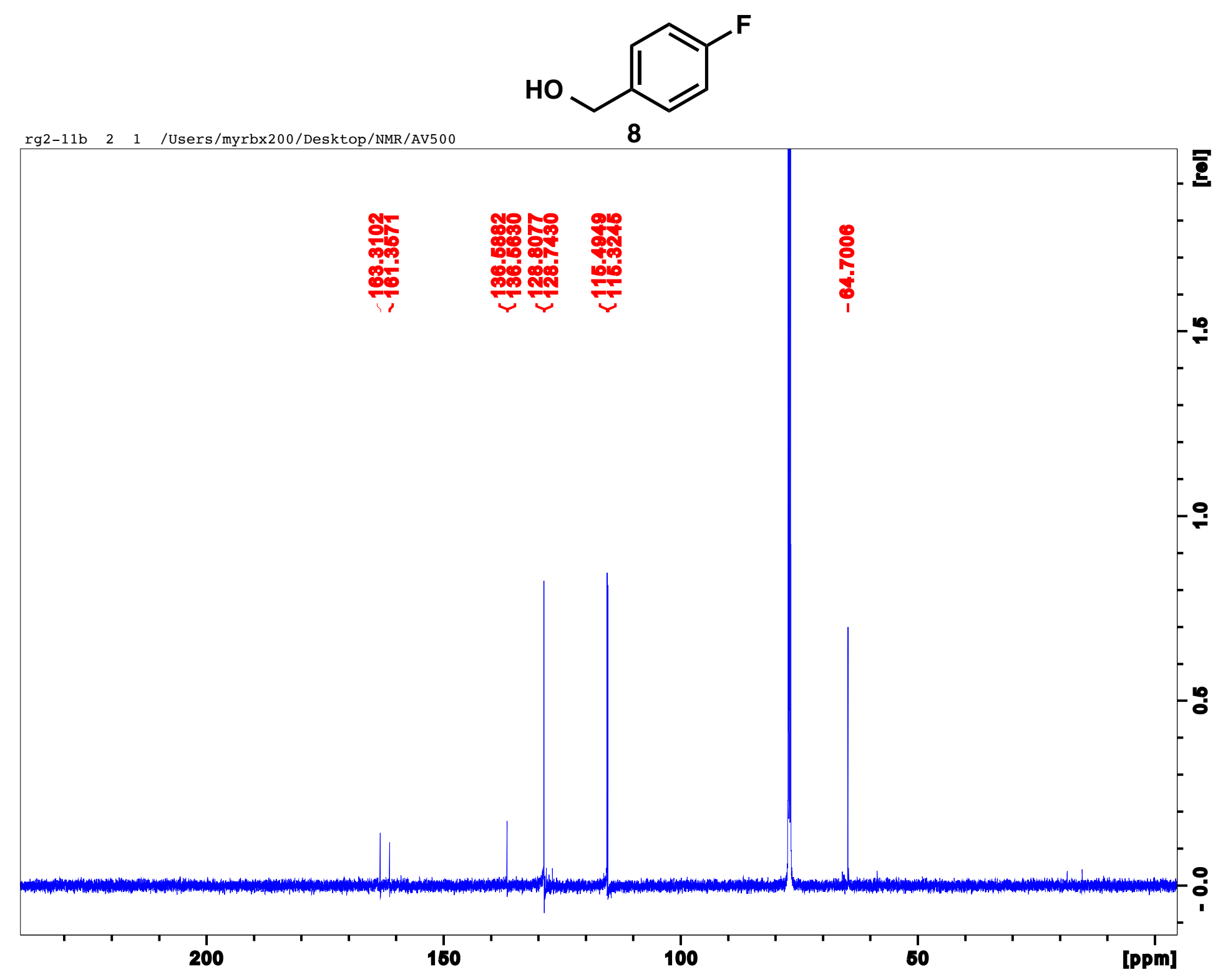


${ }^{19} \mathrm{~F}$ NMR

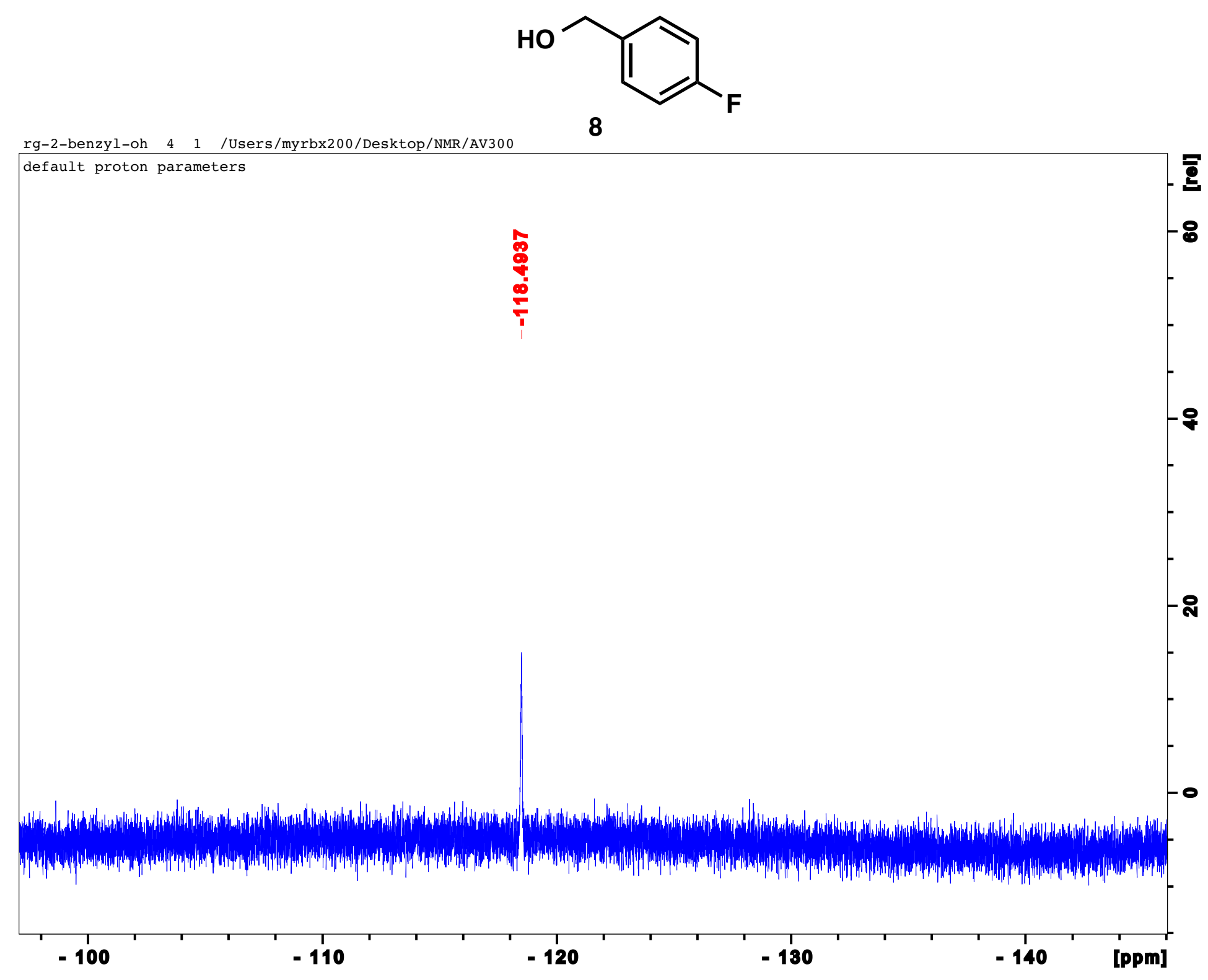


${ }^{19} \mathrm{~F}$ NMR
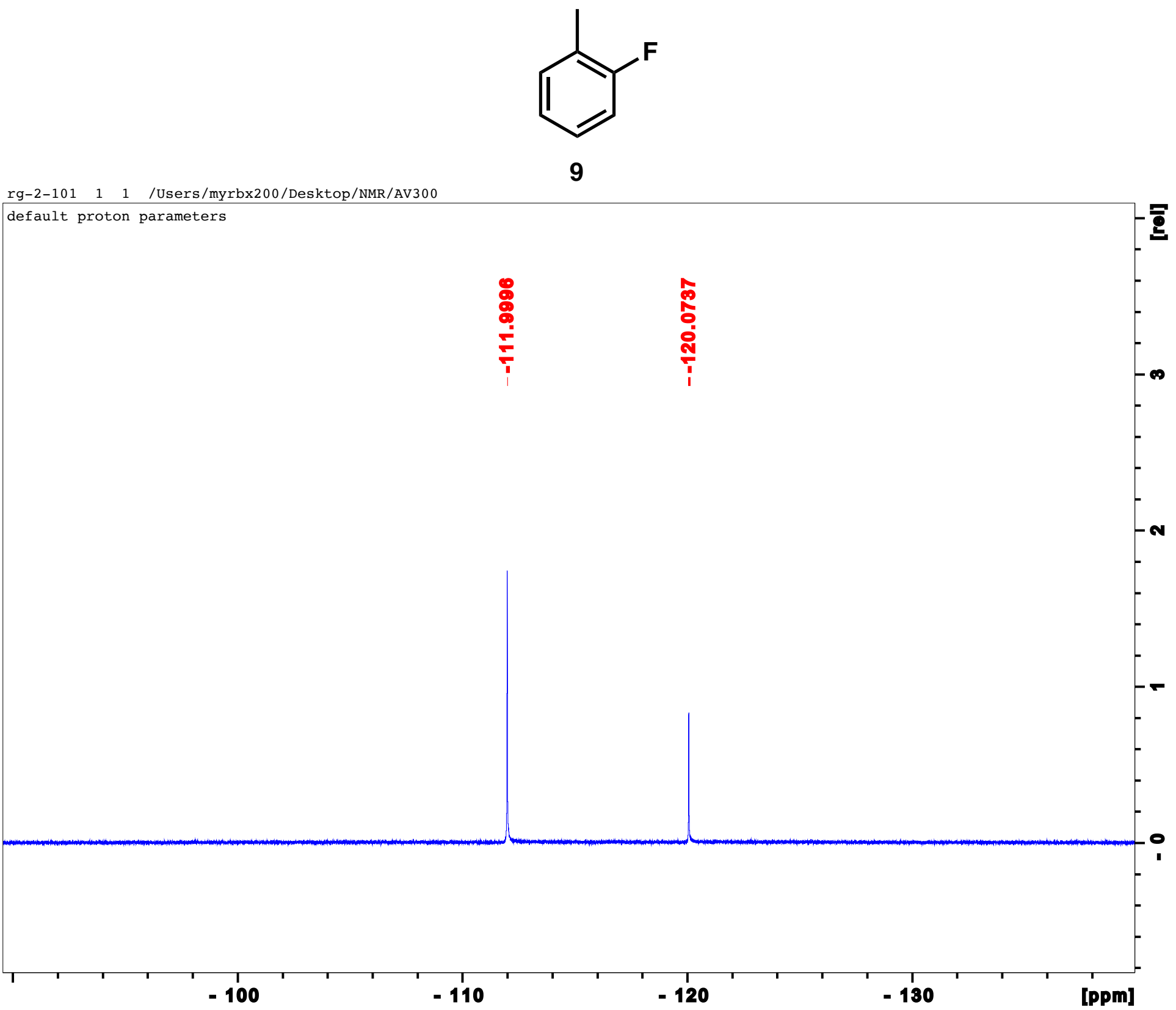
${ }^{19} \mathrm{~F}$ NMR

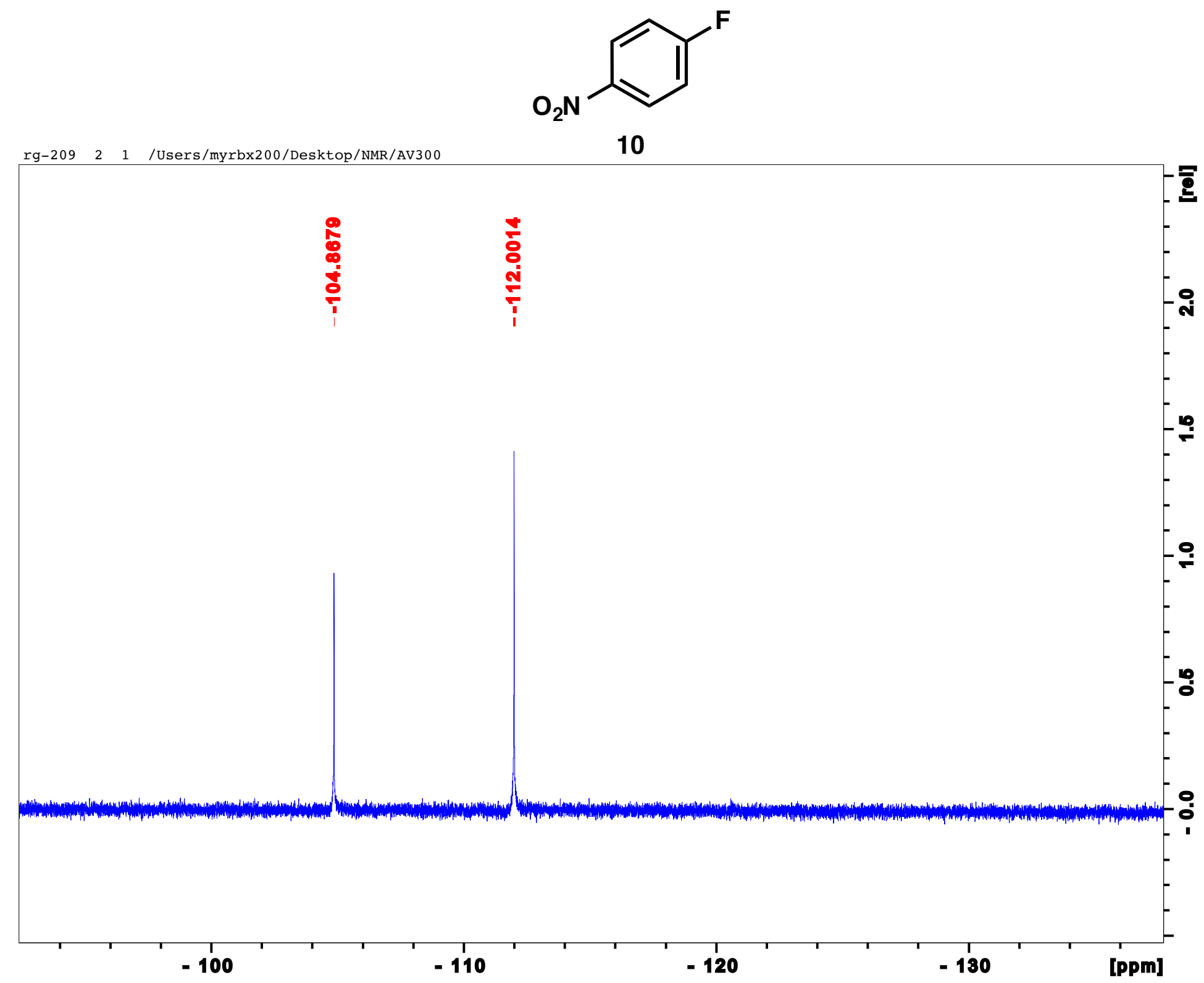


${ }^{19} \mathrm{~F}$ NMR

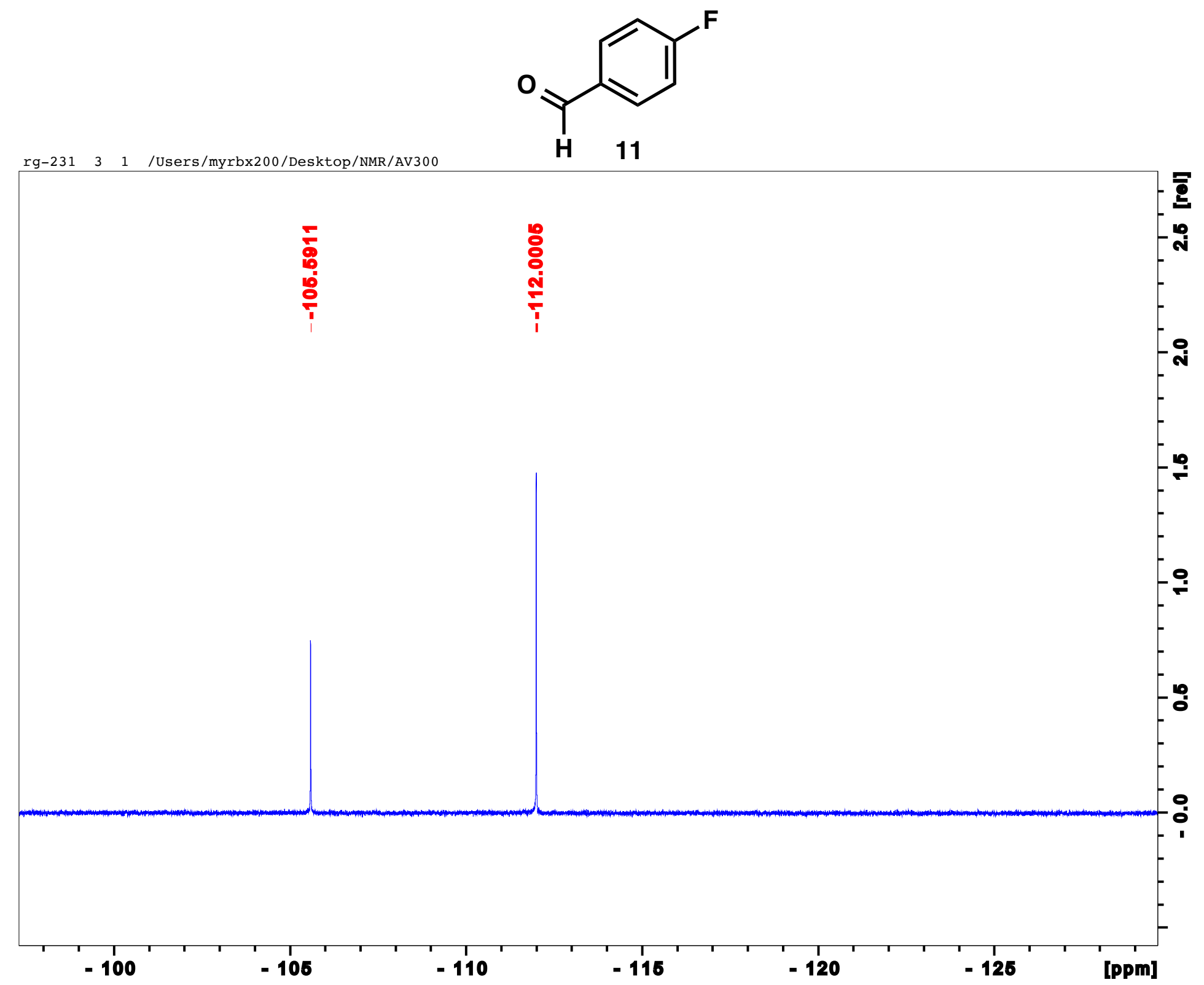


${ }^{19} \mathrm{~F}$ NMR

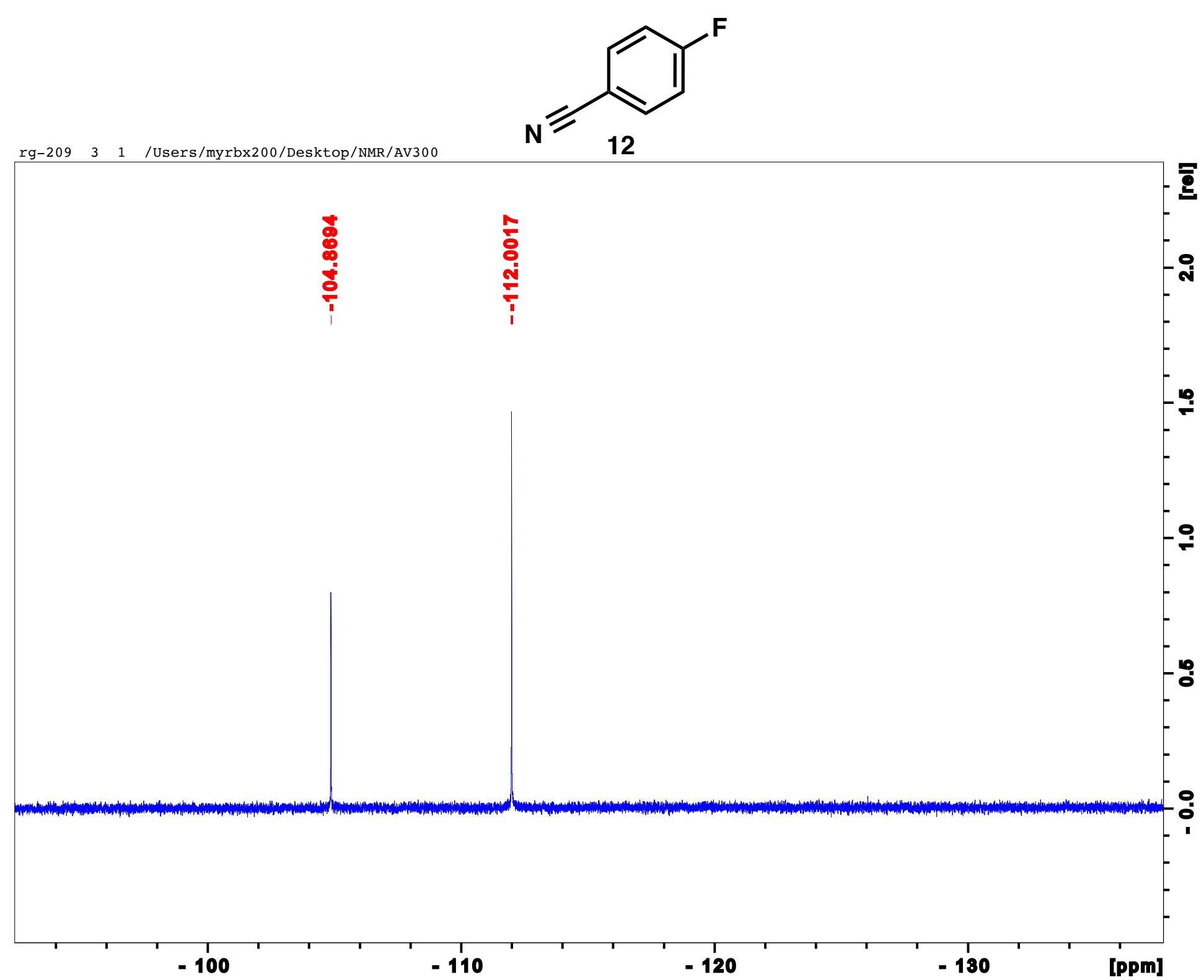


${ }^{1} \mathrm{H}$ NMR
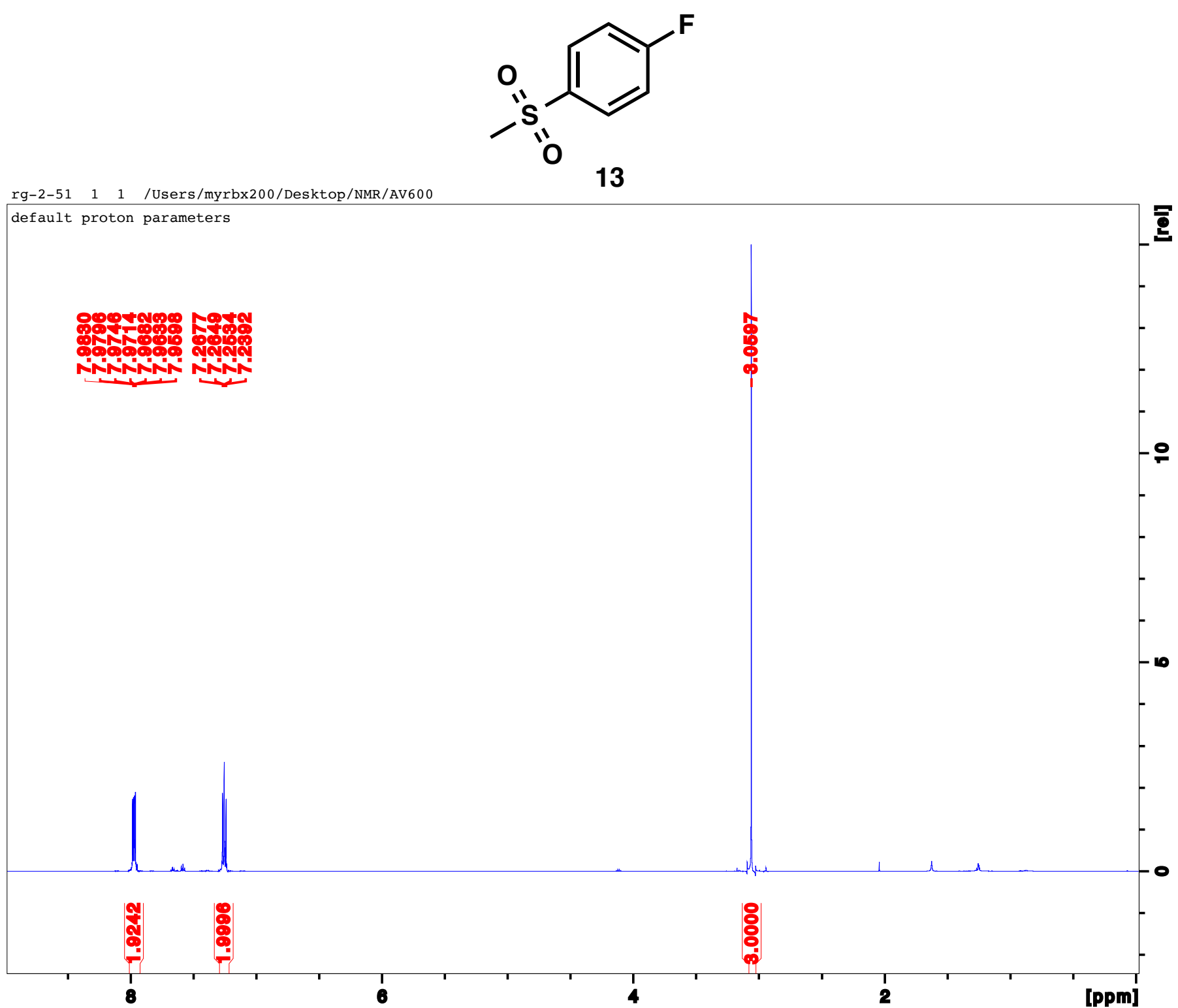
${ }^{13} \mathrm{C}$ NMR

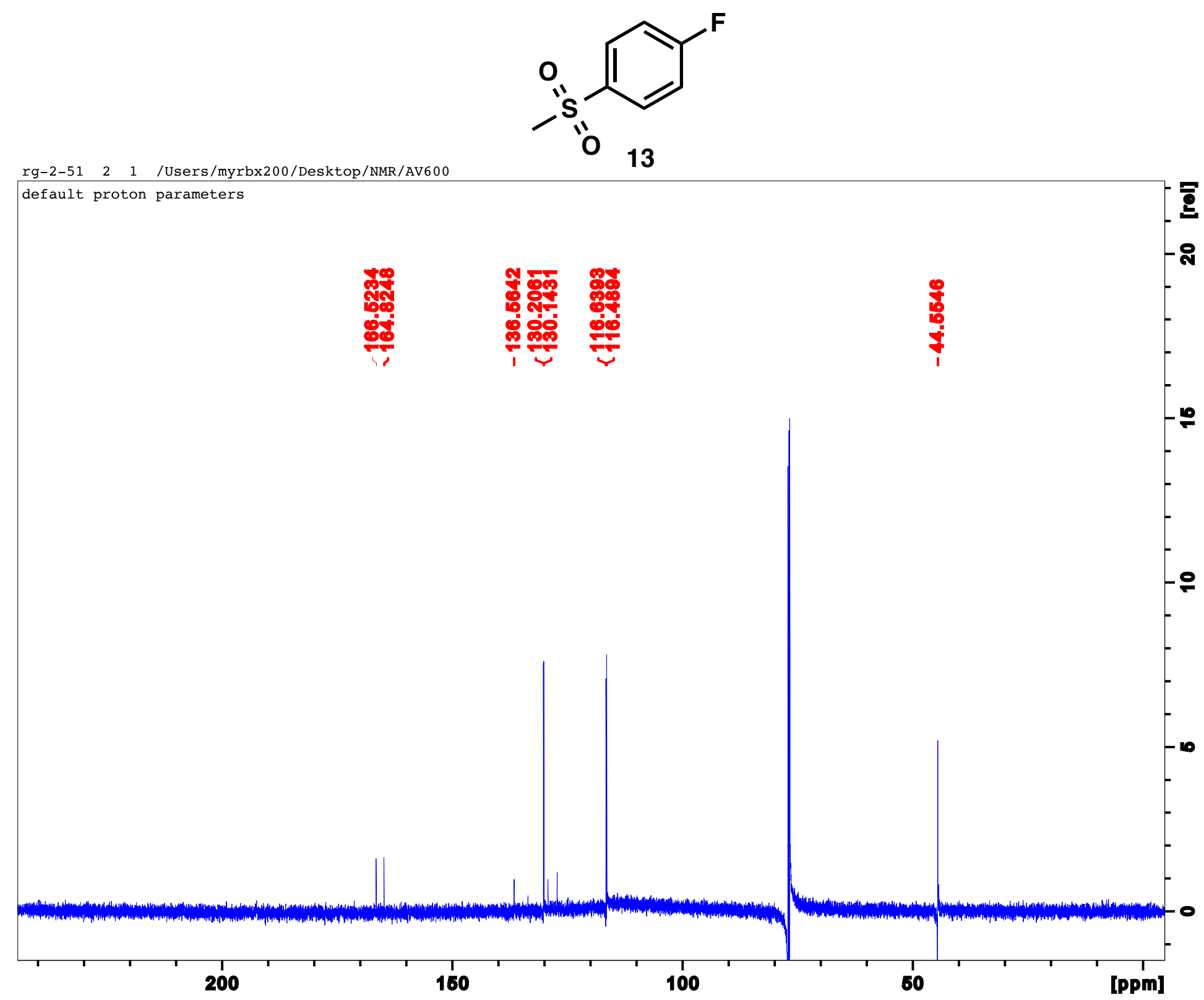


${ }^{19}$ F NMR

rg-2-sulfone $4 \quad 1$ /Users/myrbx200/Desktop/NMR/AV300<smiles>CS(=O)(=O)c1ccc(F)cc1</smiles>
default proton parameters

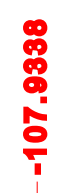

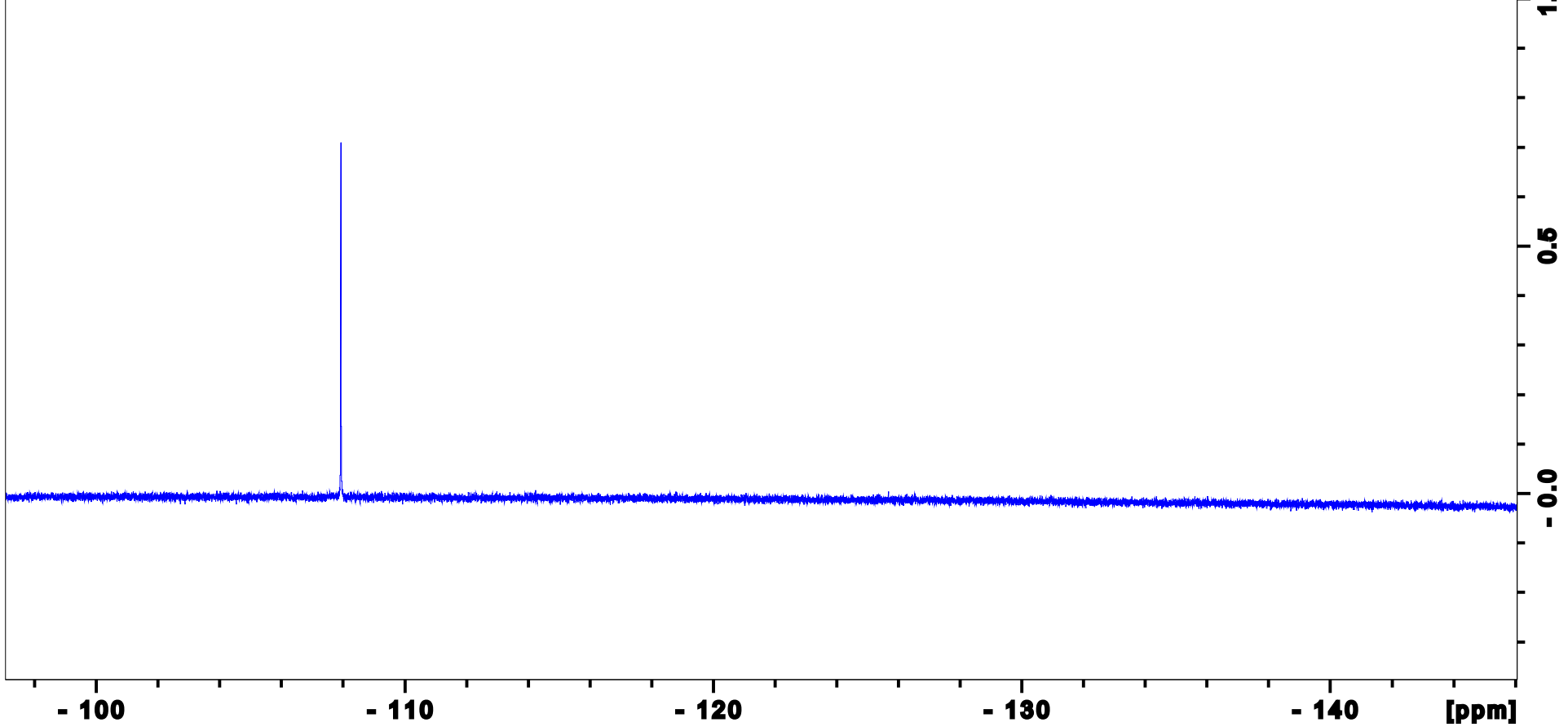


${ }^{1} \mathrm{H}$ NMR

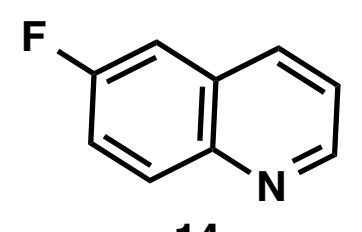

rg-250b 111 /Users/myrbx200/Desktop/NMR/AV300

14

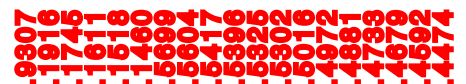

क⿻

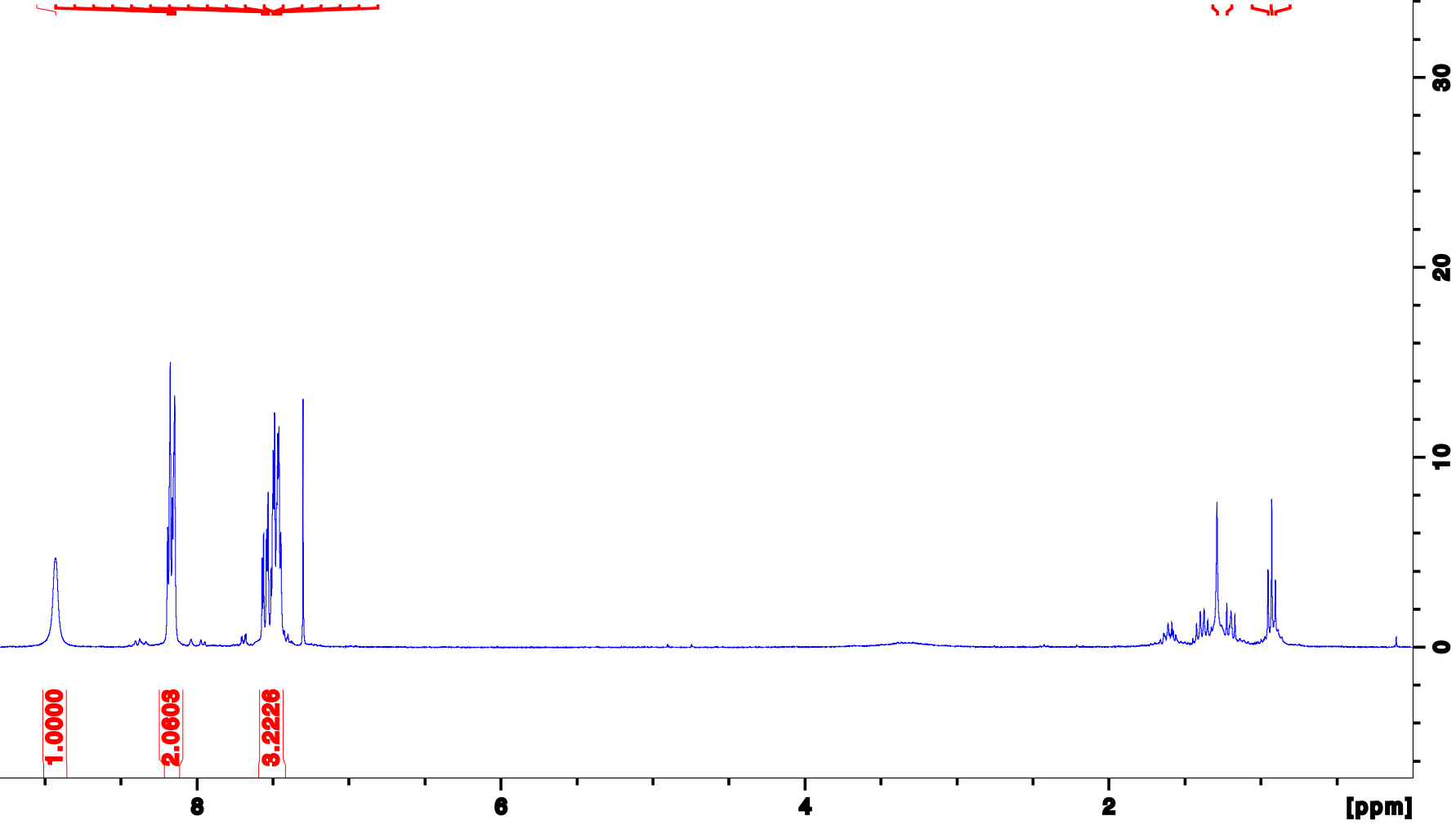




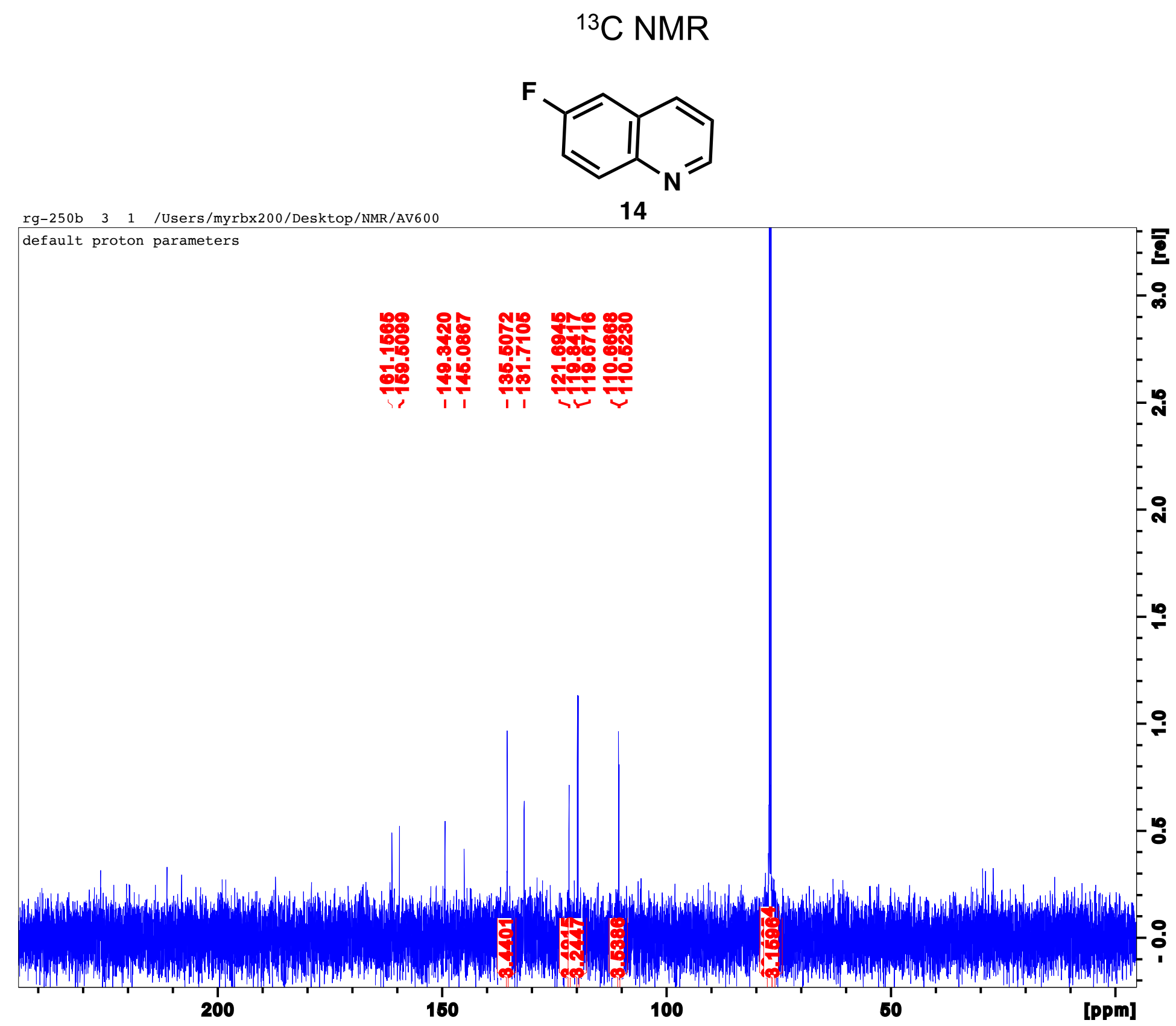


${ }^{19} \mathrm{~F}$ NMR
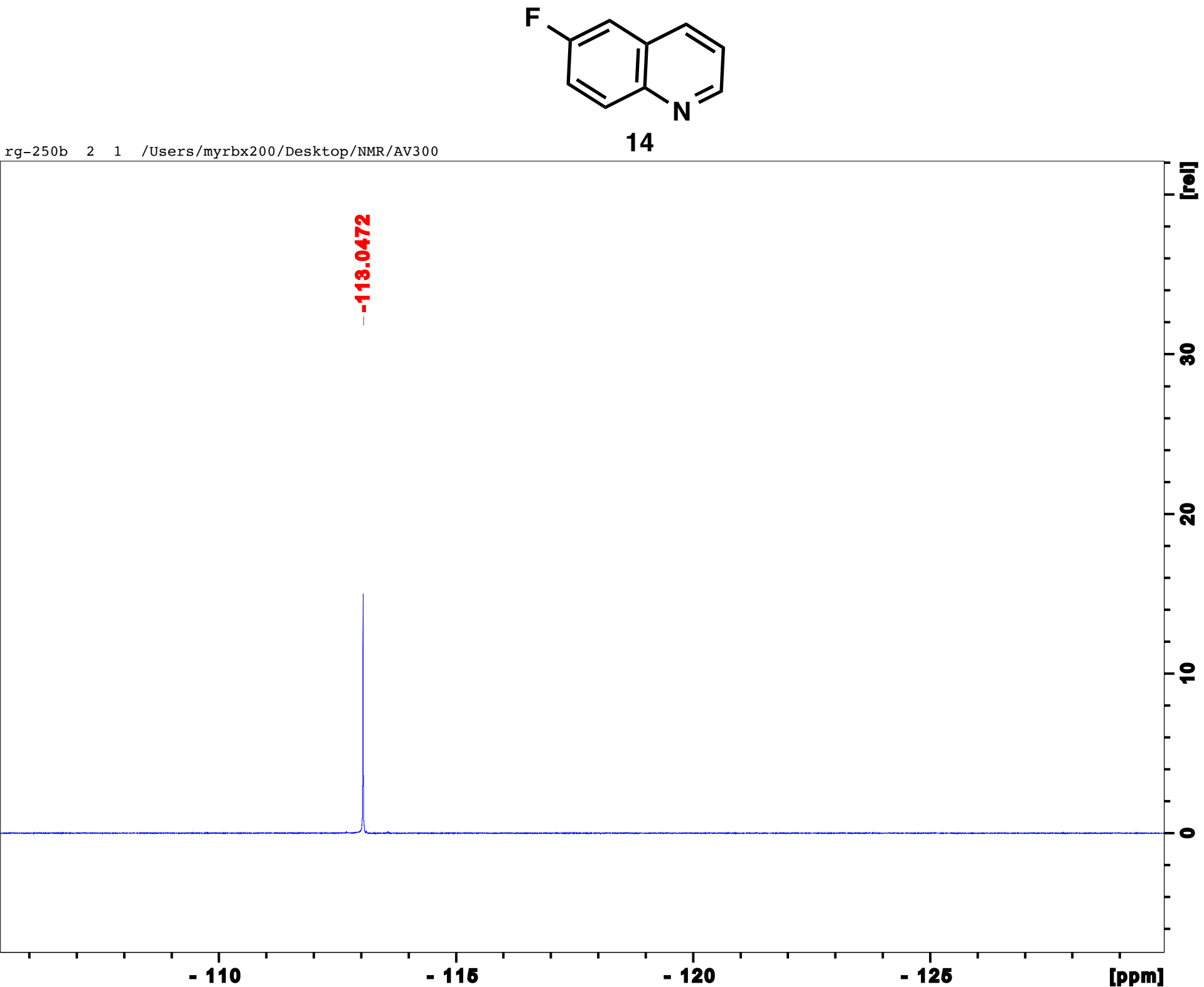
${ }^{1} \mathrm{H}$ NMR

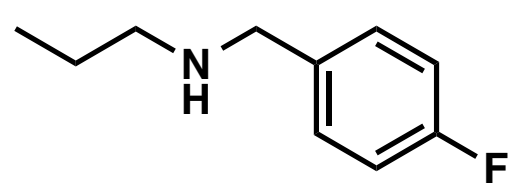

15

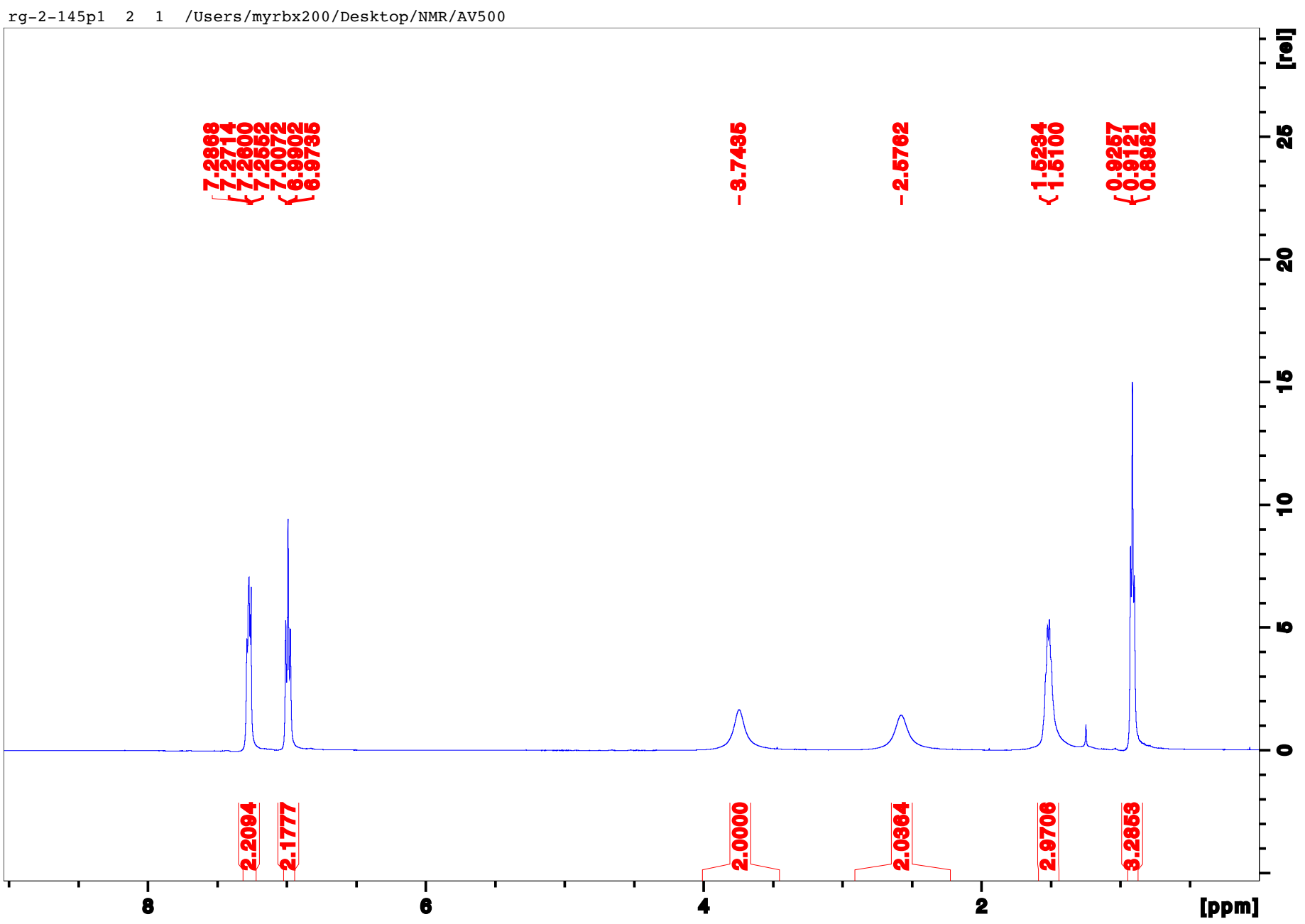


${ }^{13} \mathrm{C}$ NMR

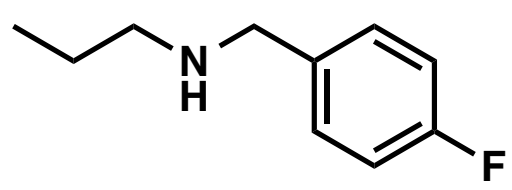

15

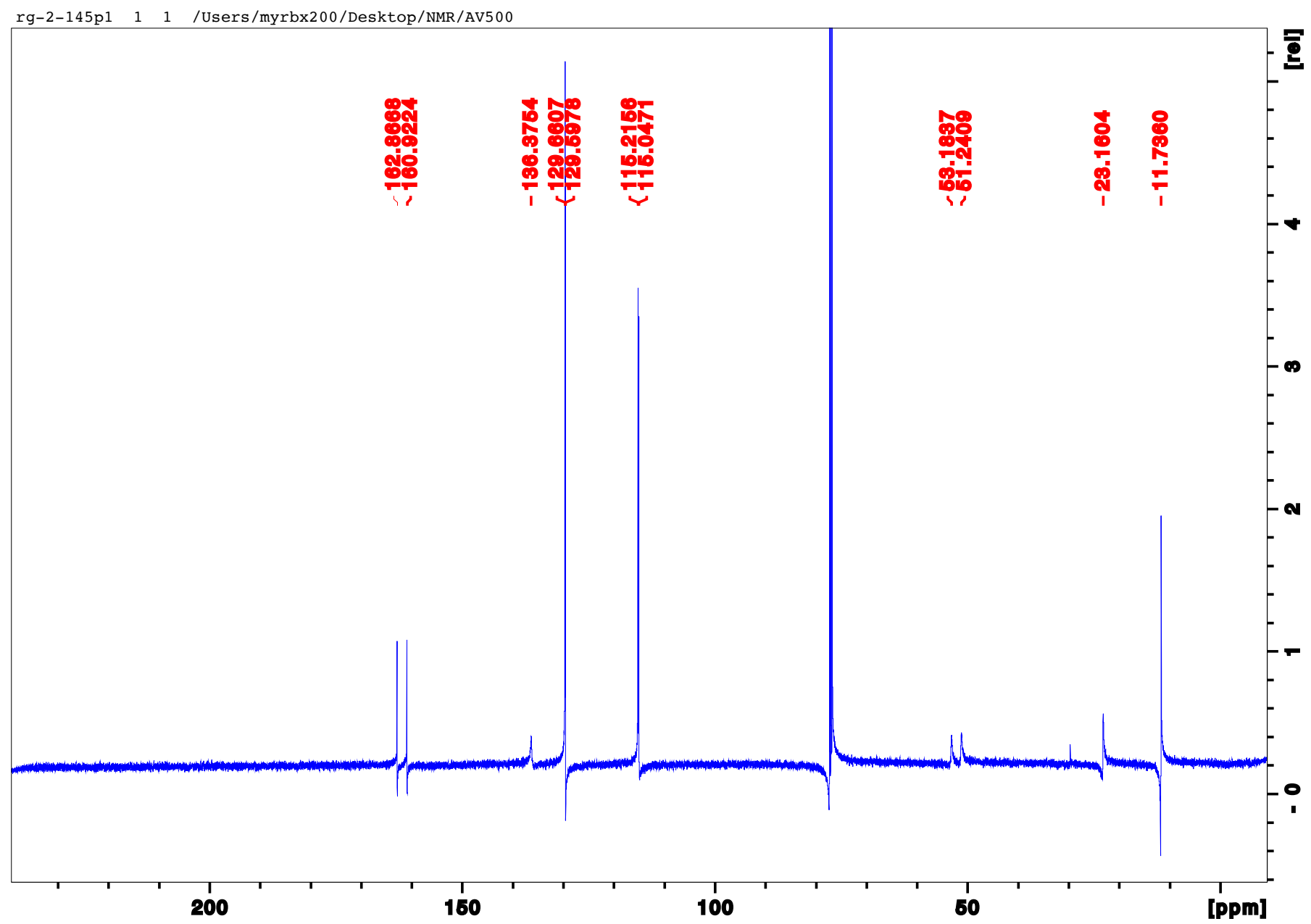


${ }^{19} \mathrm{~F}$ NMR

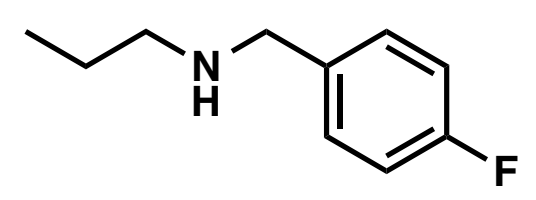

15

rg-2-94-2 3 1 /Users/myrbx200/Desktop/NMR/AV300 default proton parameters
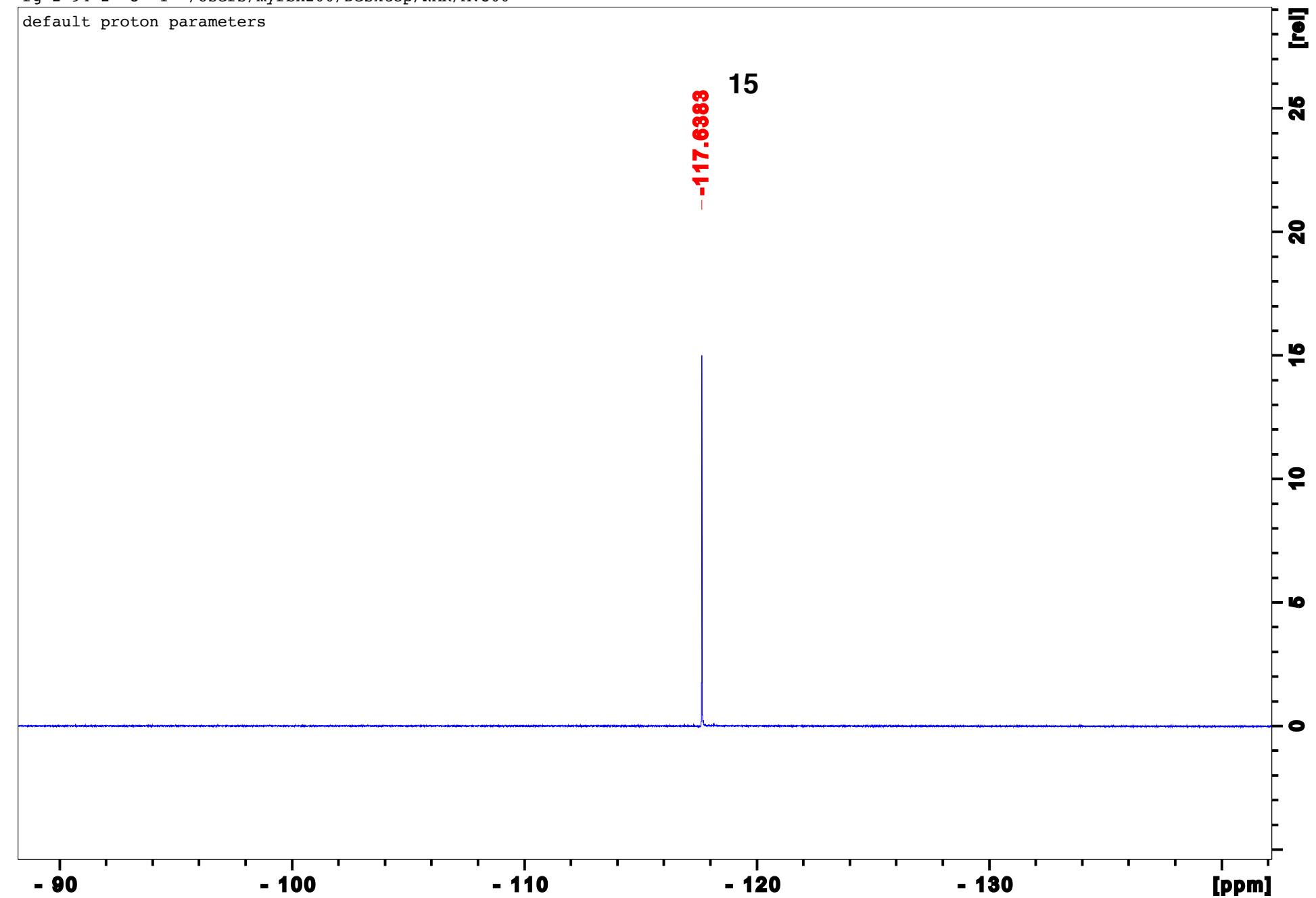
${ }^{19} \mathrm{~F}$ NMR

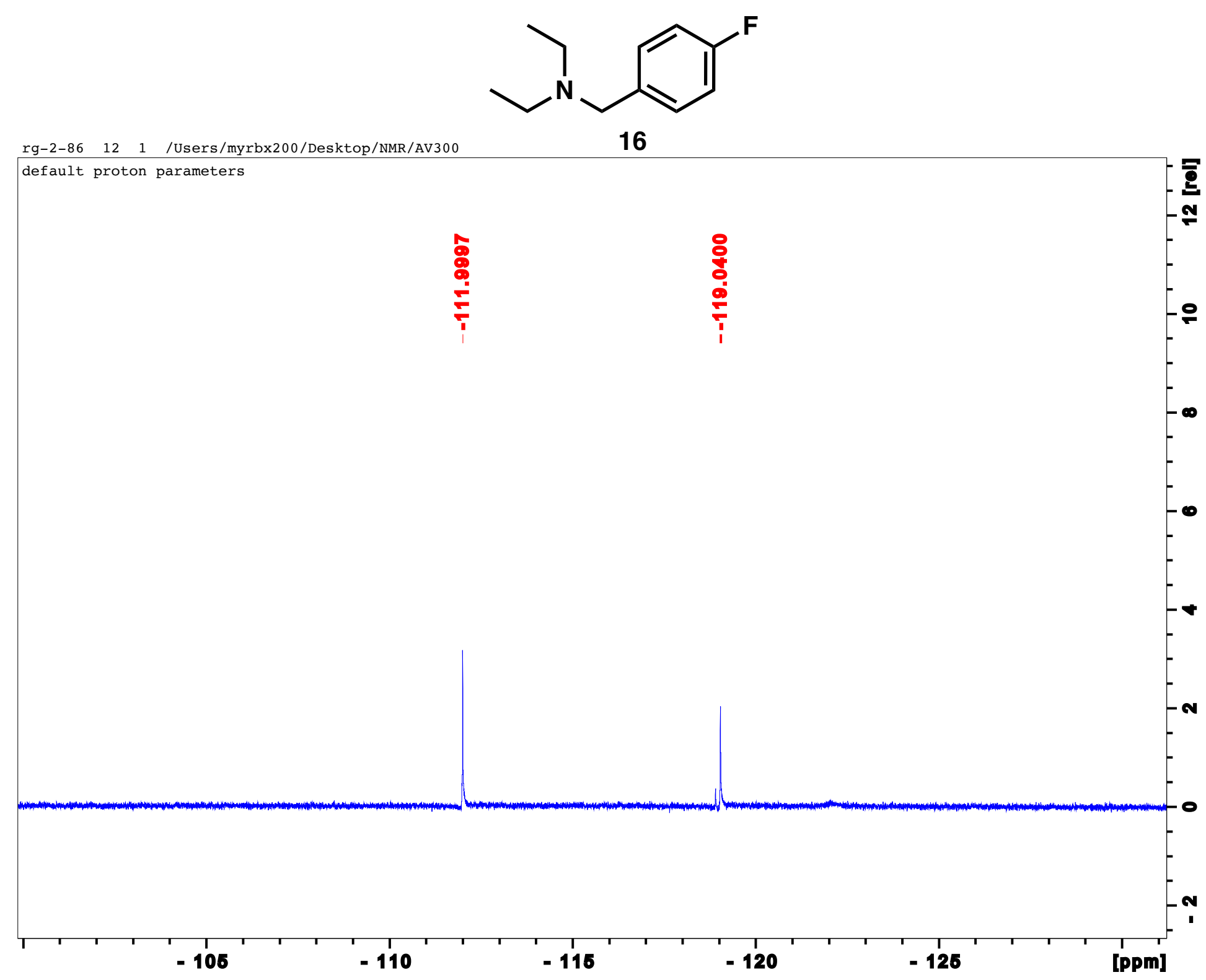


${ }^{19} \mathrm{~F}$ NMR

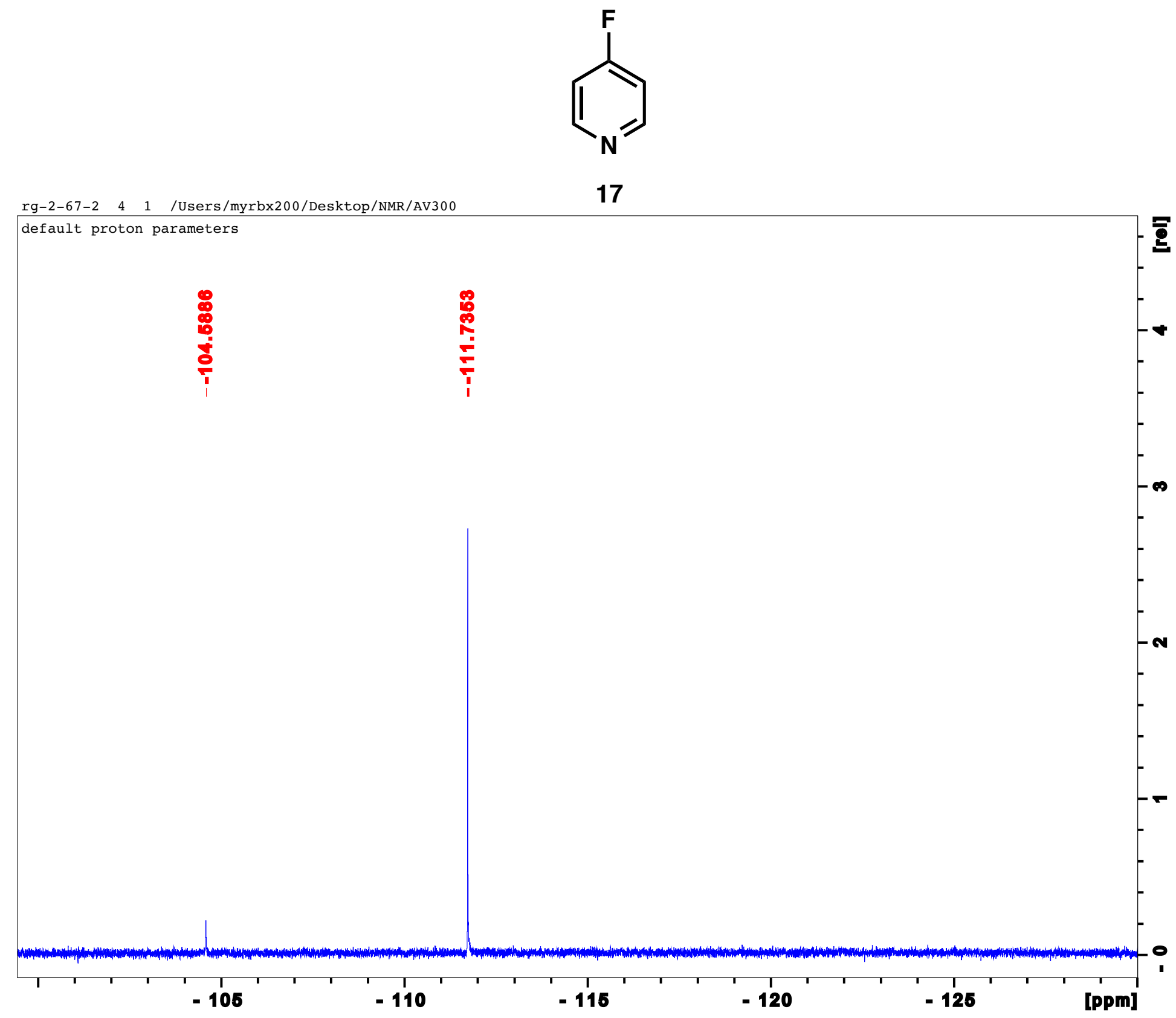


${ }^{19} \mathrm{~F}$ NMR

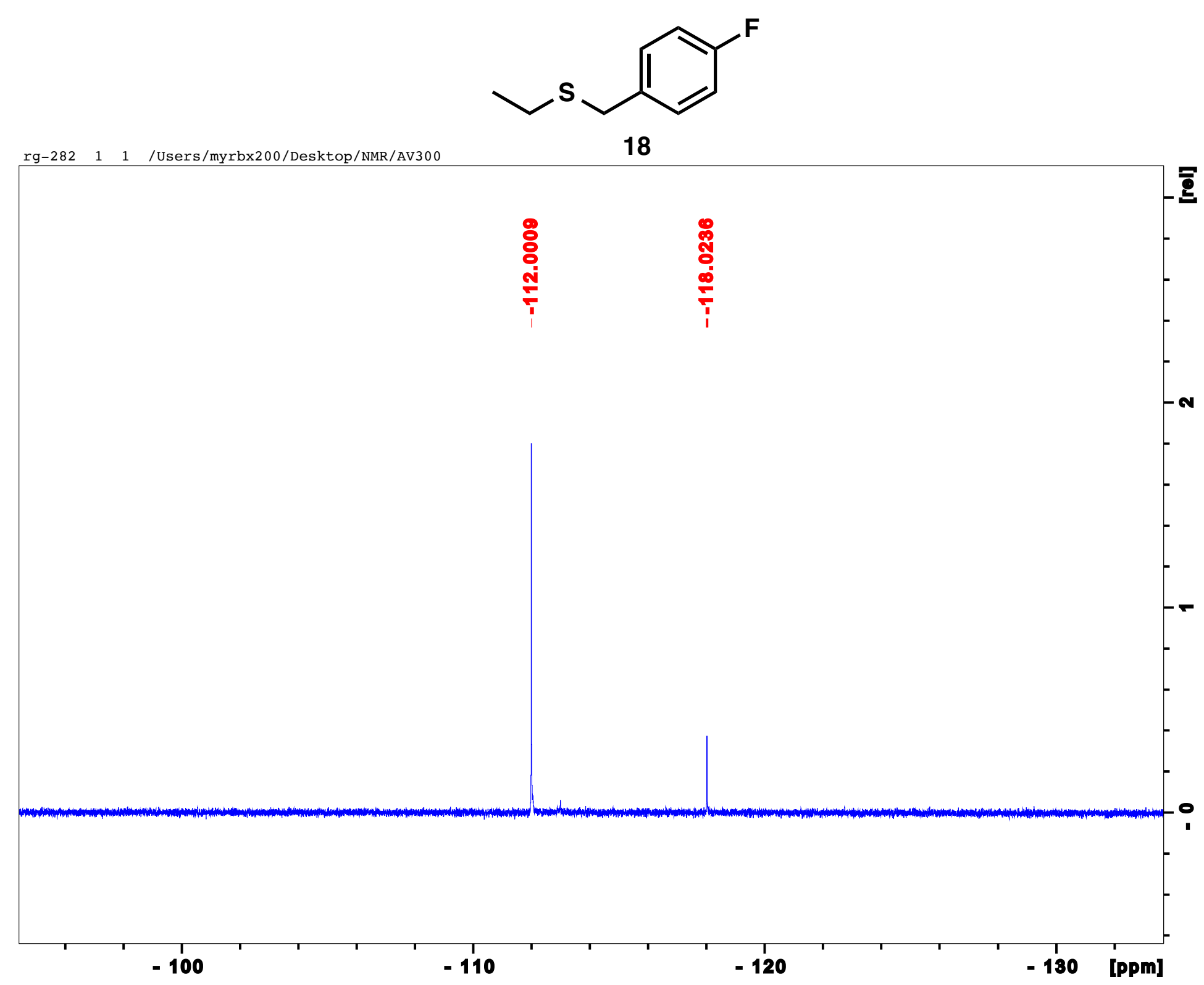


rg-2-182 111 /Users/myrbx200/Desktop/NMR/AV600
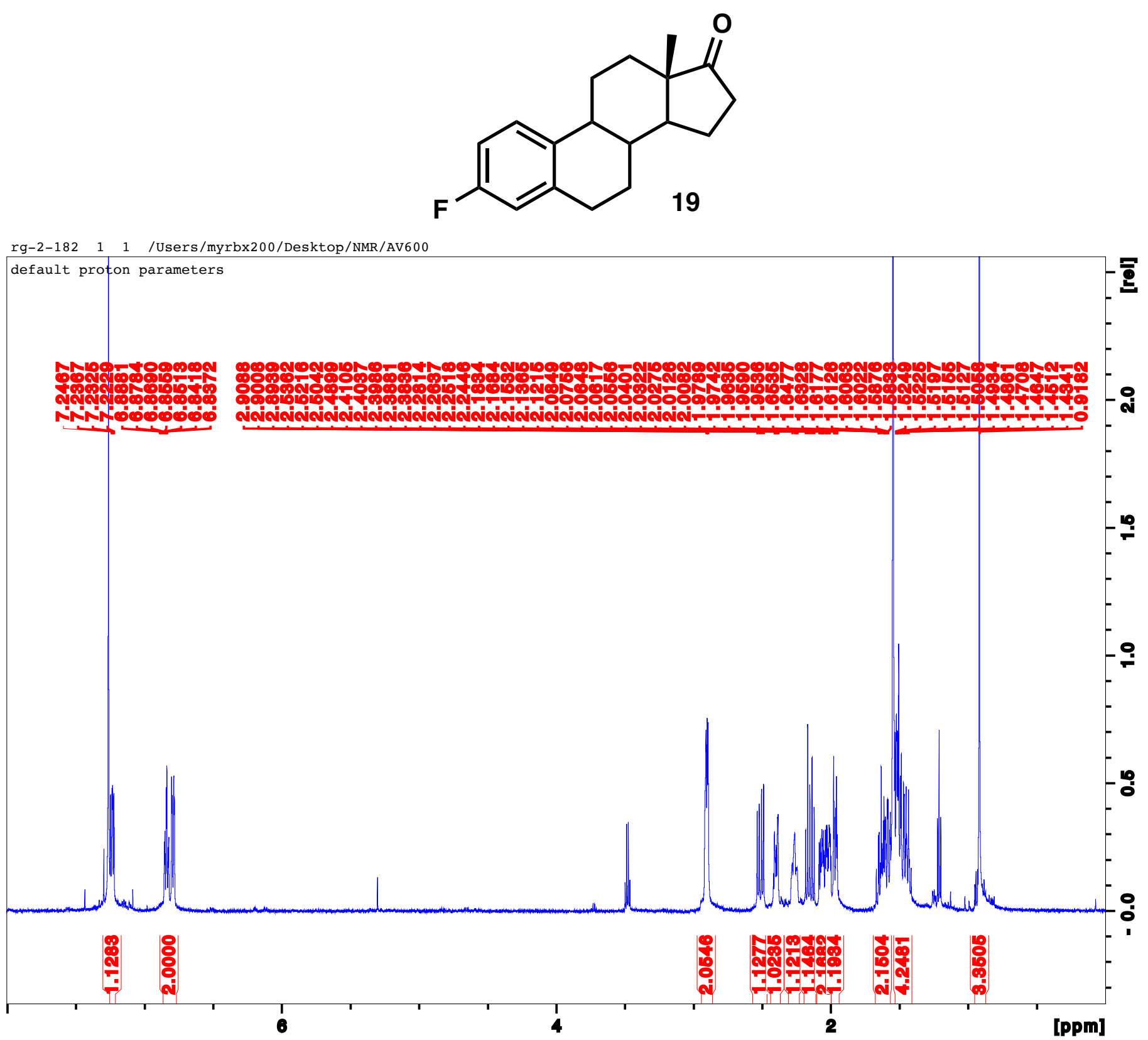
${ }^{13} \mathrm{C}$ NMR
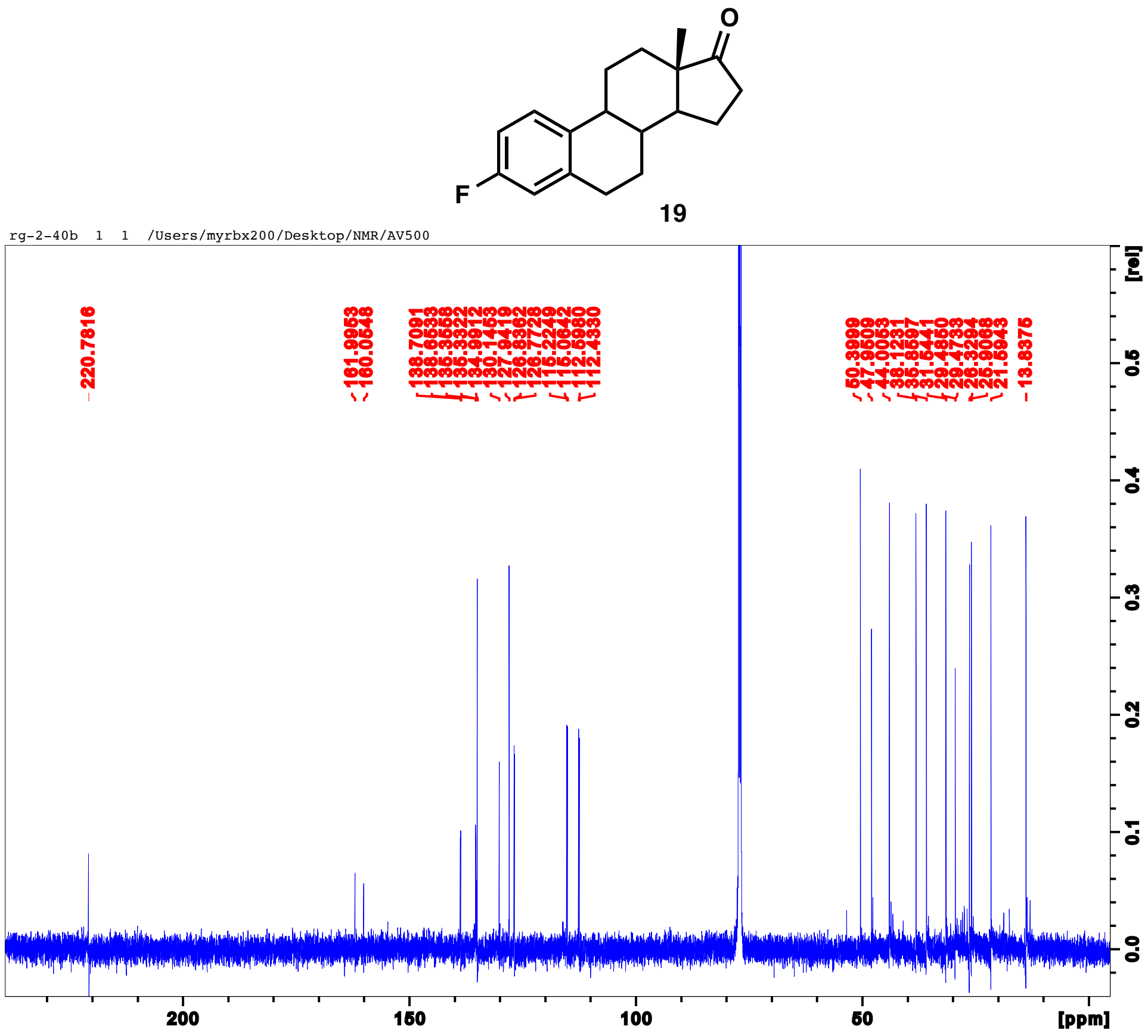


\section{${ }^{19} \mathrm{~F}$ NMR}
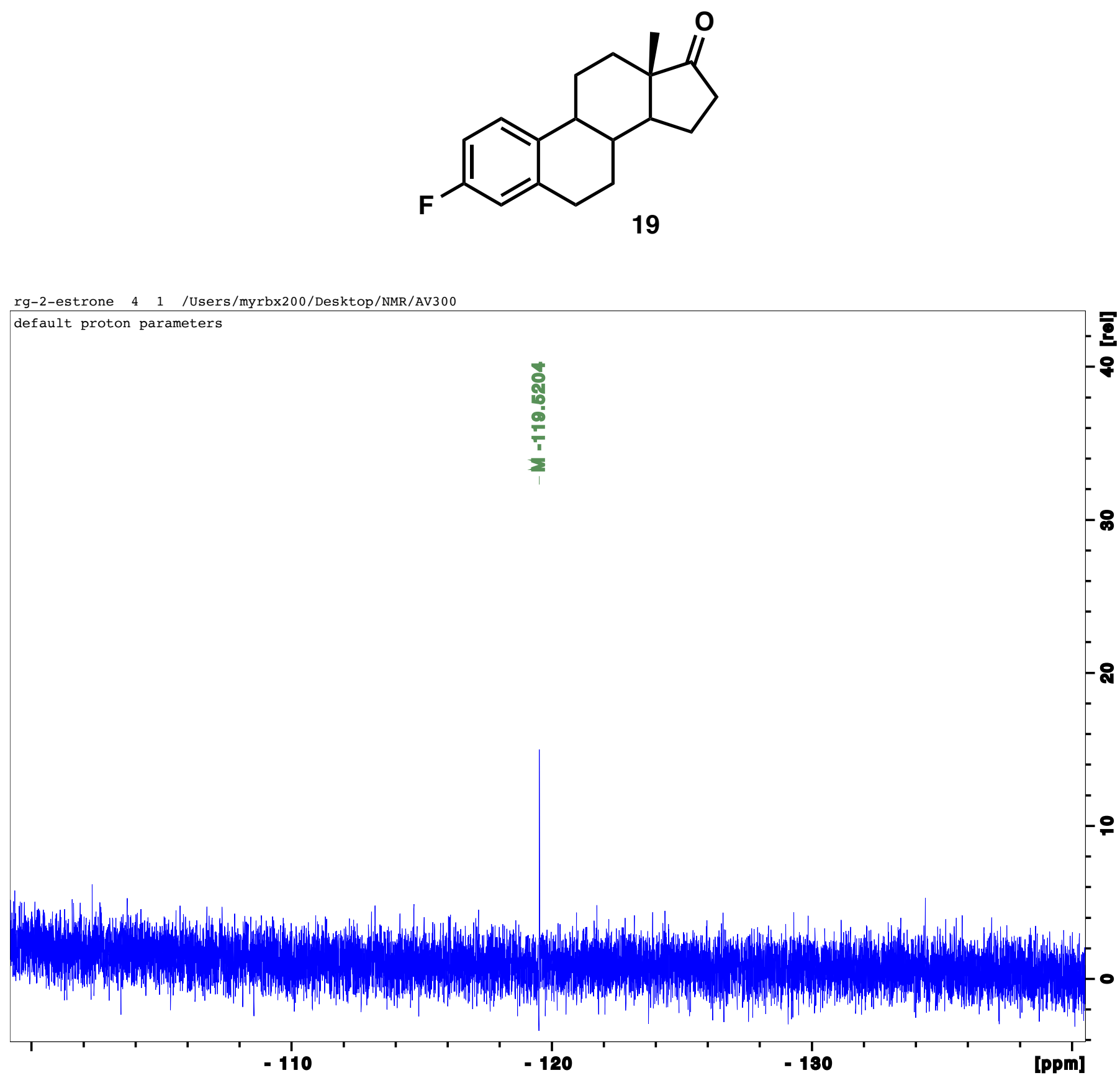